\title{
JUN 181985
}

\section{SUSPENDED-SEDIMENT YIELDS IN THE TAYLOR RUN AND SHAVERS FORK BASINS, RANDOLPH COUNTY, WEST VIRGINIA, 1973-80}

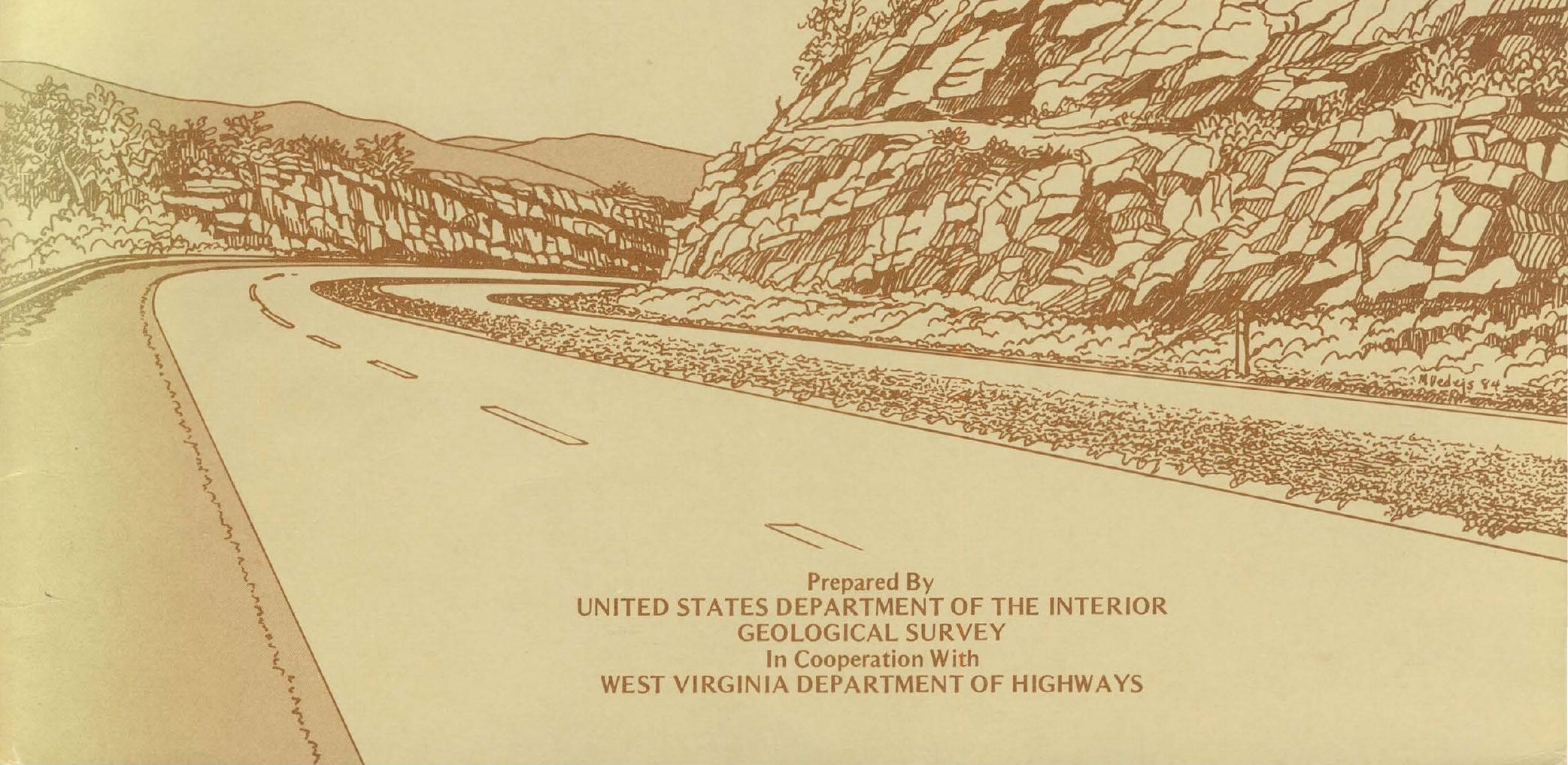




\section{SUSPENDED-SEDIMENT YIELDS IN THE TAYLOR RUN AND SHAVERS FORK BASINS, RANDOLPH COUNTY, WEST VIRGINIA, 1973-80}

By

Stephen M. Ward

U.S, GEOLOGICAL SURVEY

Water-Resources Investigations

Report 83-4040

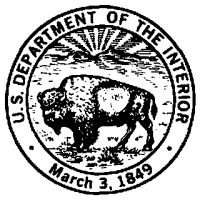

July, 1984 


\title{
UNITED STATES DEPARTMENT OF THE INTERIOR
}

\author{
WILLIAM P. CLARK, SECRETARY
}

\section{GEOLOGICAL SURVEY}

\author{
Dallas L. Peck, Director
}

For additional information write to:

District Chief

U.S. Geological Survey, WRD

603 Morris Street

Charleston, West Virginia 25301 


\section{CONTENTS}

Page

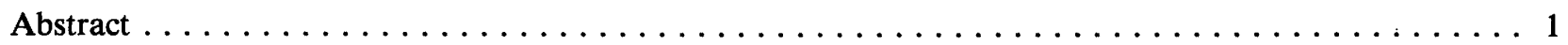

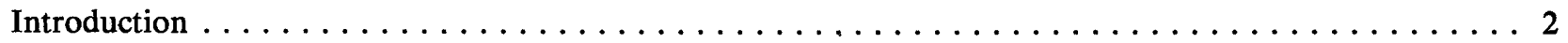

Basin characteristics affecting sediment yields $\ldots \ldots \ldots \ldots \ldots \ldots \ldots \ldots \ldots \ldots \ldots \ldots \ldots \ldots$

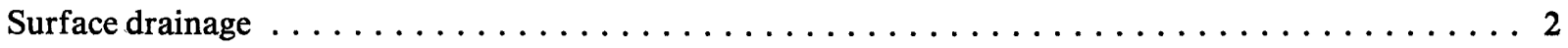

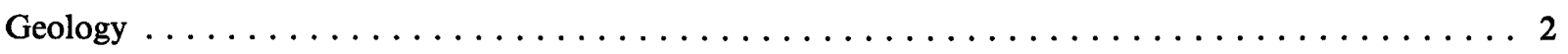

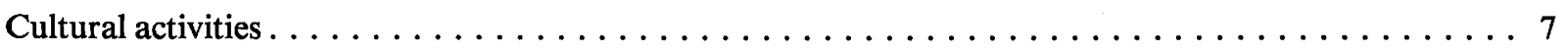

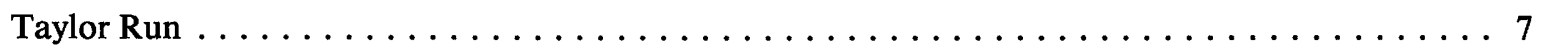

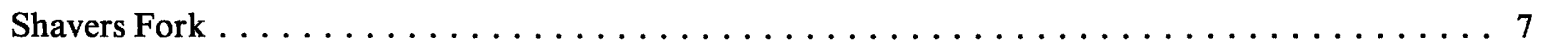

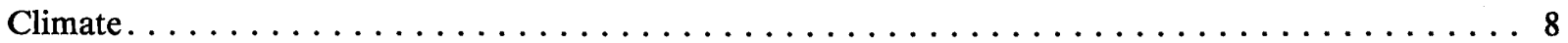

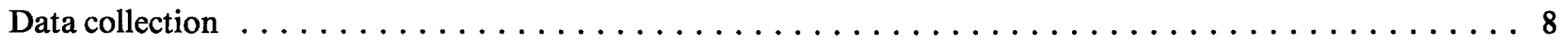

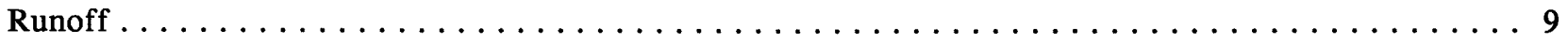

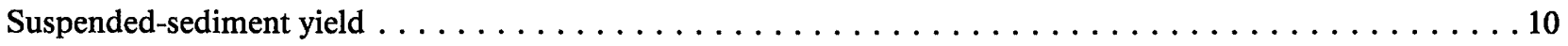

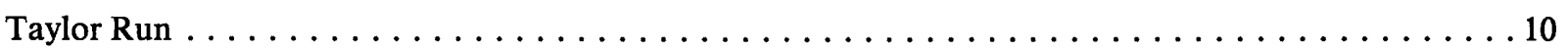

Upper Taylor Run $\ldots \ldots \ldots \ldots \ldots \ldots \ldots \ldots \ldots \ldots \ldots \ldots \ldots \ldots \ldots \ldots$

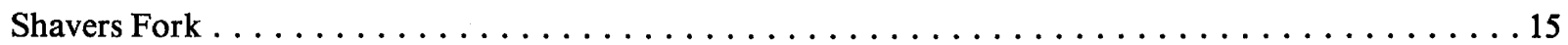

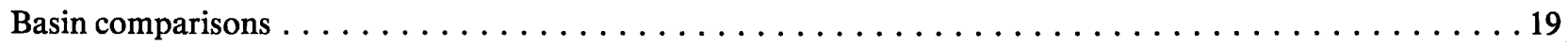

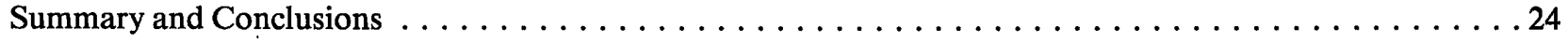

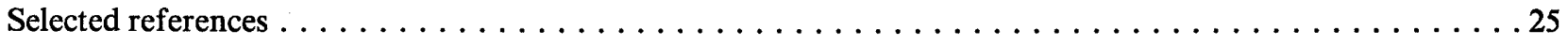

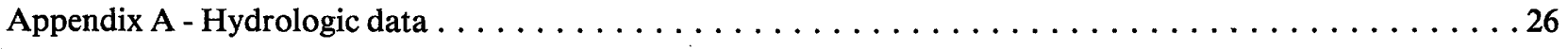

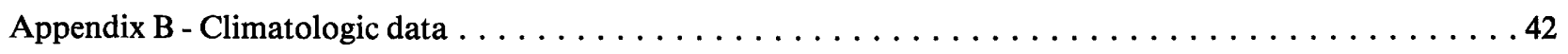

\section{ILLUSTRATIONS}

Figure 1. Map showing major features of Taylor Run and Shavers Fork

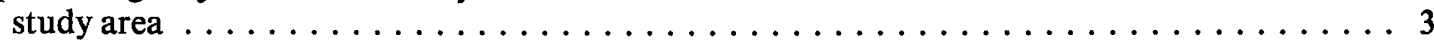

2. Map of location of completed and proposed highway through Taylor Run

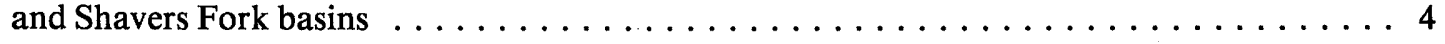

3. Map of generalized geology of Taylor Run basin $\ldots \ldots \ldots \ldots \ldots \ldots \ldots \ldots \ldots \ldots$

4. Graph showing precipitation, by water year, at rain gages at South Spring,

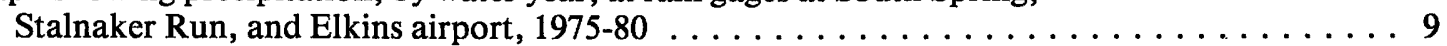

5. Graph showing departure of monthly and water-year precipitation from

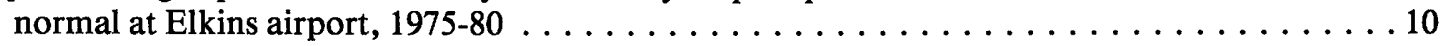

6. Graph showing cumulative monthly suspended-sediment discharge and streamflow from Taylor Run, October 1974 to September 1980 . . . . . . . . . . . . . . . . . . . 13 
7. Graph showing suspended-sediment concentrations and precipitation data for storms in Taylor Run, June 1, 1974, July 3, 1978 and July 3, 1980

8. Graph showing annual suspended-sediment yield at Taylor Run at Bowden,

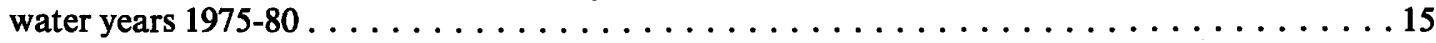

9. Graph showing regression curves of suspended-sediment load versus streamflow

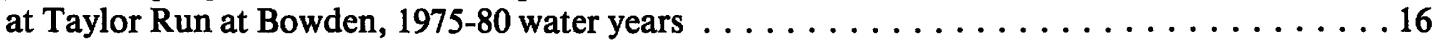

10. Graph showing cumulative monthly suspended-sediment discharge and streamflow at Shavers Fork below Bowden, June 1975 to September $1980 \ldots \ldots \ldots \ldots \ldots$

11. Graph showing annual suspended-sediment yield at Shavers Fork above and

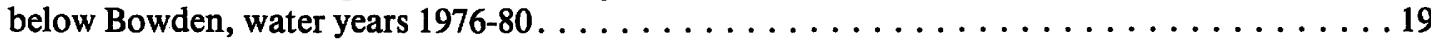

12. Graph showing regression curves of suspended-sediment load versus streamflow

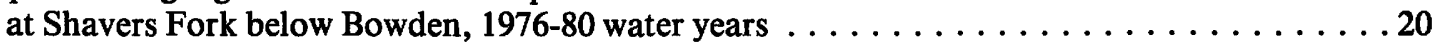

13. Graph showing the cumulative suspended-sediment discharge at Taylor Run and Shavers Fork, July 1975 to September $1980 \ldots \ldots \ldots \ldots \ldots \ldots \ldots \ldots$

14. Graph showing average daily suspended-sediment yield at Taylor Run

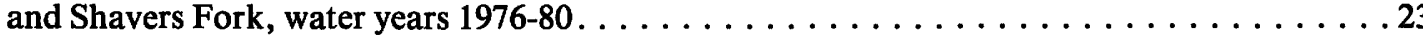

\section{TABLES}

\section{Page}

Table 1. Monthly and annual precipitation at Elkins airport during

$1941-70$ (normal period) . . . . . . . . . . . . . . . . . . . . . . . . 10

2. Data-collection sites within Taylor Run-Shavers Fork study area $\ldots \ldots \ldots \ldots \ldots \ldots \ldots \ldots 11$

3. Annual precipitation and runoff, in inches, for gaging sites in the

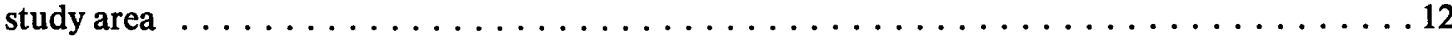

4. Annual suspended-sediment discharge and streamflow at the Taylor Run

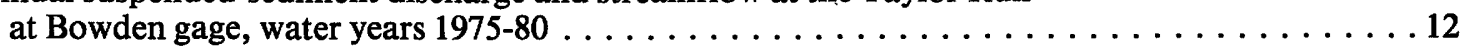

5. Data for three major storms in the Taylor Run basin, $1974-80 \ldots \ldots \ldots \ldots \ldots \ldots \ldots$

6. Annual suspended-sediment discharge and streamflow at the Shavers Fork below Bowden gage, water years $1976-80 \ldots \ldots \ldots \ldots \ldots \ldots \ldots \ldots \ldots \ldots$

7. Average daily suspended-sediment yield for gaging stations in the

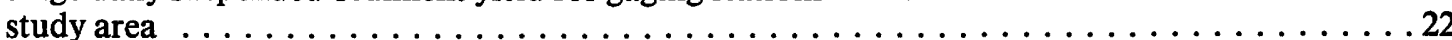




\section{FACTORS FOR CONVERTING INCH-POUND UNITS TO INTERNATIONAL SYSTEM OF UNITS (SI)}

\section{For the convenience of readers who may want to use the International System of Units (SI), the data may be converted by using the following factors:}

\section{Multiply}

inch (in.)

foot (ft)

mile (mi)

acre

square mile $\left(\mathrm{mi}^{2}\right)$

ton, short

ton per square mile (ton $/ \mathrm{mi}^{2}$ )

cubic foot per second $\left(\mathrm{ft}^{3} / \mathrm{s}\right)$

cubic foot per second

per square mile $\left[\left(\mathrm{ft}^{3} / \mathrm{s}\right) / \mathrm{mi}^{2}\right]$

cubic foot per second-day $\left(\mathrm{ft}^{3} / \mathrm{s}-\mathrm{d}\right)$

cubic yard $\left(\mathrm{yd}^{3}\right)$

degree Fahrenheit $\left({ }^{\circ} \mathrm{F}\right)$
By

25.40

0.3048

1.609

0.4047

2.590

0.9072

0.3502

0.02832

0.01093

0.02832

0.7646

$-32 \times 5 / 9$
To obtain

millimeter (mm)

meter $(\mathrm{m})$

kilometer $(\mathrm{km})$

hectare (ha)

square kilometer $\left(\mathrm{km}^{2}\right)$

megagram $(\mathrm{Mg})$

megagram per square kilometer $\left(\mathrm{Mg} / \mathrm{km}^{2}\right)$

cubic meter per second $\left(\mathrm{m}^{3} / \mathrm{s}\right)$

cubic meter per second per square kilometer $\left[\left(\mathrm{m}^{3} / \mathrm{s}\right) / \mathrm{km}^{2}\right]$

cubic meter per second-day $\left(\mathrm{m}^{3} / \mathrm{s}-\mathrm{d}\right)$

cubic meter $\left(\mathrm{m}^{3}\right)$

degree Celsius $\left({ }^{\circ} \mathrm{C}\right)$

National Geodetic Vertical Datum of 1929 (NGVD of 1929): A geodetic datum derived from a general adjustment of the first-order level nets of both the United States and Canada, formerly called mean sea level. NGVD of 1929 is referred to as sea level in this report. 


\title{
SUSPENDED-SEDIMENT YIELDS IN THE TAYLOR RUN AND SHAVERS FORK BASINS, RANDOLPH COUNTY, WEST VIRGINIA, 1973-80
}

\author{
By
}

Stephen M. Ward

\begin{abstract}
Precipitation, streamflow, and sediment data were collected in two adjacent basins near Bowden, West Virginia, to evaluate the effects of highway construction (Appalachian Corridor H) on streamsediment discharge. From October 1974 to September 1980 (1975-80 water years), daily suspendedsediment data were collected in the 5.06-square-mile Taylor Run basin to provide background data in anticipation of highway construction. However, construction was halted near the mouth of Taylor Run just east of the Shavers Fork crossing pending evaluation of an Environmental Impact Statement. Construction was completed in the late summer of 1976. Daily suspended-sediment data were collected on the main stem of Shavers Fork from July 1975 to September 1980 to evaluate the sediment discharge associated with areas already excavated and filled.
\end{abstract}

About 2,340 tons of suspended sediment was discharged past the gaging station at Taylor Run at Bowden (5.06 square miles) during the 1975-80 water years. The maximum daily yield of 32 tons per square mile and the maximum daily precipitation of 3.30 inches occurred on July 3, 1980. Annual suspended-sediment yields ranged from 23 to 140 tons per square mile. Sediment produced by man's activities in Taylor Run during the investigation was slight. High sediment yields were usually associated with intense storms in this small, steep, forested drainage.

Suspended-sediment yield was high during and immediately after an 11-month logging operation
(1977-78) in Taylor Run but declined significantly during 1979, even though precipitation increased. Annual suspended-sediment discharge in relation to runoff decreased nearly 10 percent. Precipitation during this time increased 25 percent to about 60 inches. High suspended-sediment concentrations were measured, however, in the Stalnaker Run basin, a tributary to Taylor Run, where the soil has not been disturbed since logging operations in 1970.

About 112,000 tons of suspended sediment was discharged past the gaging station at Shavers Fork below Bowden (151 square miles) during the 1976-80 water years. The maximum daily yield of 108 tons per square mile was associated with a large storm during March 1977, which accounted for 53 percent of the total load for the water year and nearly 15 percent of the load for the 5-year investigation. Annual suspended-sediment yields ranged from 39 to 204 tons per square mile. Sediment produced by man's activities in the Shavers Fork drainage was varied and of greater magnitude than in Taylor Run.

Sediment yields stabilized in the main stem of Shavers Fork approximately 2 years after completion of Corridor $\mathrm{H}$ construction. Sediment yields were high after highway completion during the 1977 water year, when two major storms produced 75 percent of the annual suspended-sediment load. Runoff during the 1978-80 water years ranged from 38.5 to 42.5 inches per year, and suspended-sediment yields ranged from 154 to 175 tons per square mile. 


\section{INTRODUCTION}

A cooperative study by the U.S. Geological Survey and the West Virginia Department of Highways was begun in 1973 to evaluate sediment yields associated with highway construction. The first phase was the collection of hydrologic data from the Taylor Run basin [5.06 $\mathrm{mi}^{2}$ (square miles)] and a 5-mi (mile) reach of the Shavers Fork in northeastern West Virginia. The study area is near Bowden, Randolph County, 8 mi east of Elkins, West Virginia (fig. 1). Taylor Run is a tributary of Shavers Fork, a popular trout stream, and is $1 \mathrm{mi}$ east of the Bowden National Fish Hatchery (fig. 2). A segment of the Shavers Fork basin is also discussed in this report in reference to a completed 5-mi segment of four-lane divided highway that ends near the mouth of Taylor Run (fig. 2). This is the first segment of the Appalachian Corridor $\mathrm{H}$, which would ultimately connect Interstate 79 in central West Virginia and Interstate 81 in central .Virginia.

Data collection began in April 1973 and ended in September 1980 with modifications in the type and frequency of collection. Suspended-sediment samples were collected once or twice daily during low flow and more frequently during high flows by local observers and verified by comparison with periodic samples collected by U.S. Geological Survey personnel. The study was revised in 1978 to provide for more intensive data collection in Taylor Run in anticipation of further highway construction. However, highway construction was delayed indefinitely to consider alternative locations persuant to Federal regulations before adopting a final location. Various construction alternatives are now being evaluated by the West Virginia Department of Highways and the Federal Highway Administration.

Initially this study was designed to determine the effects of highway construction on sediment yields in the Taylor Run basin by separating the sediment contribution from logging and mining areas. Because the highway construction has been delayed, this report discusses only variations in sediment yields relative to the revegetation and soil stabilization associated with highway construction along the main stem of Shavers Fork and variations in sediment yields associated with the logging activities in Taylor Run. This study did not attempt to divide the total sediment load of Shavers Fork into components contributed by individual activity. Insufficient data were available to determine sediment yields in Shavers Fork before or during highway construction.
This report evaluates data on a "water year" basis. A water year is defined as the period from October 1 of a previous calendar year to September 30 of the referenced year.

\section{BASIN CHARACTERISTICS AFFECTING SEDIMENT YIELDS}

\section{Surface Drainage}

The study area is west of the Allegheny Front, which divides the Appalachian Plateaus province from the Valley and Ridge province (fig. 1). A dendritic drainage system characterizes the long narrow valleys of the Appalachian Plateaus province. Valley walls are moderately steep to steep. The steep slopes and rough topography cause high rates of soil erosion.

Taylor Run originates $2.6 \mathrm{mi}$ northeast of Bowden at an altitude of 3,100 ft (feet) and drains into Shavers Fork $1 / 2$ mi upstream from Bowden at an altitude of $2,220 \mathrm{ft}$. Stalnaker Run is the largest tributary to Taylor Run.

Shavers Fork originates at an altitude of 4,500 $\mathrm{ft}$ in Pocahontas County. It flows $83.4 \mathrm{mi}$, falls $2,875 \mathrm{ft}$, and drains $213 \mathrm{mi}^{2}$. Shavers Fork, at the downstream boundary of the study area, $26 \mathrm{mi}$ upstream from the mouth at an altitude of $2,110 \mathrm{ft}$, drains $151 \mathrm{mi}^{2}$. The highway construction parallels Shavers Fork for about $5 \mathrm{mi}$. The average fall of Shavers Fork in the $5 \mathrm{mi}$ between Taylor Run and the lower limit of highway construction is $22 \mathrm{ft} / \mathrm{mi}$ (feet per mile).

\section{Geology}

The generalized stratigraphy of the Taylor Run basin, from the youngest to oldest, is the Pottsville Group of the Pennsylvanian Period and the Mauch Chunk and Greenbrier Groups of the Mississippian Period. The axis of the North Potomac-Georges Creek Syncline coincides closely with the Taylor Run stream valley (fig. 3).

The geology of the Shavers Fork basin upstream from the mouth of Taylor Run is essentially the same as in Taylor Run, with the exception of about $20 \mathrm{mi}$ of alluvium along the stream from the 


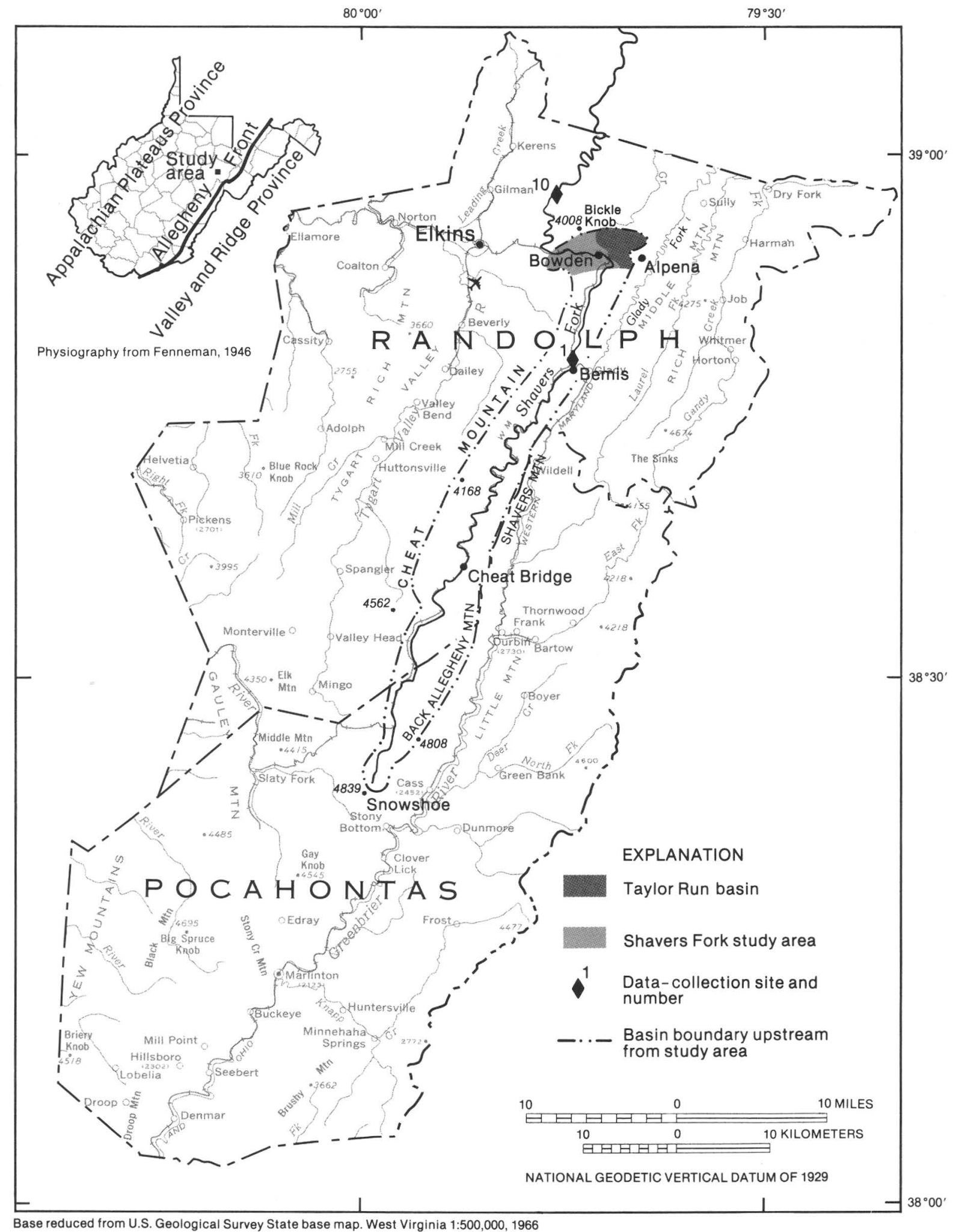

Figure 1. Major features of Taylor Run and Shavers Fork study area. 


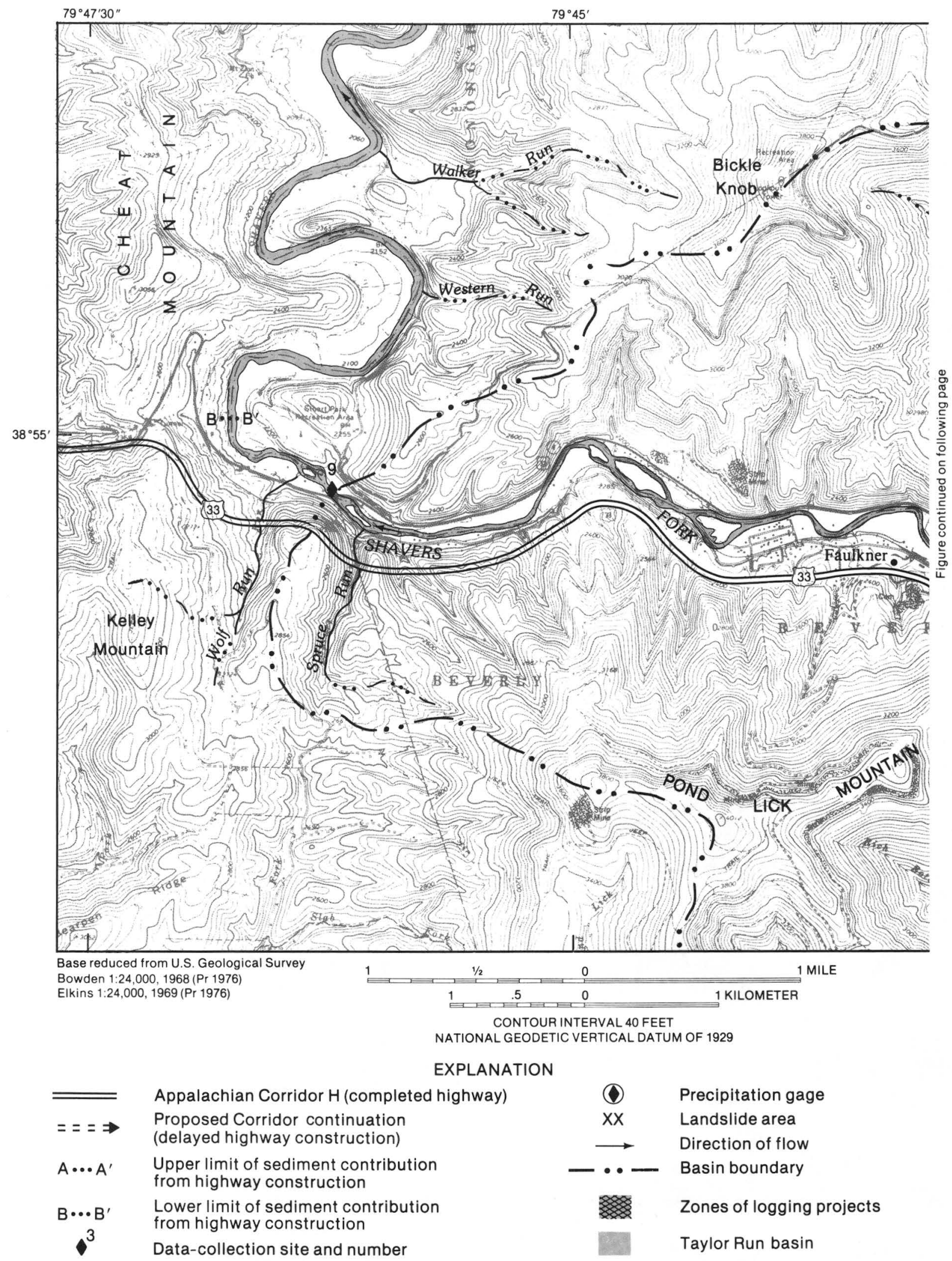

Figure 2. Location of completed and proposed highway through Taylor Run and Shavers Fork Basins. 


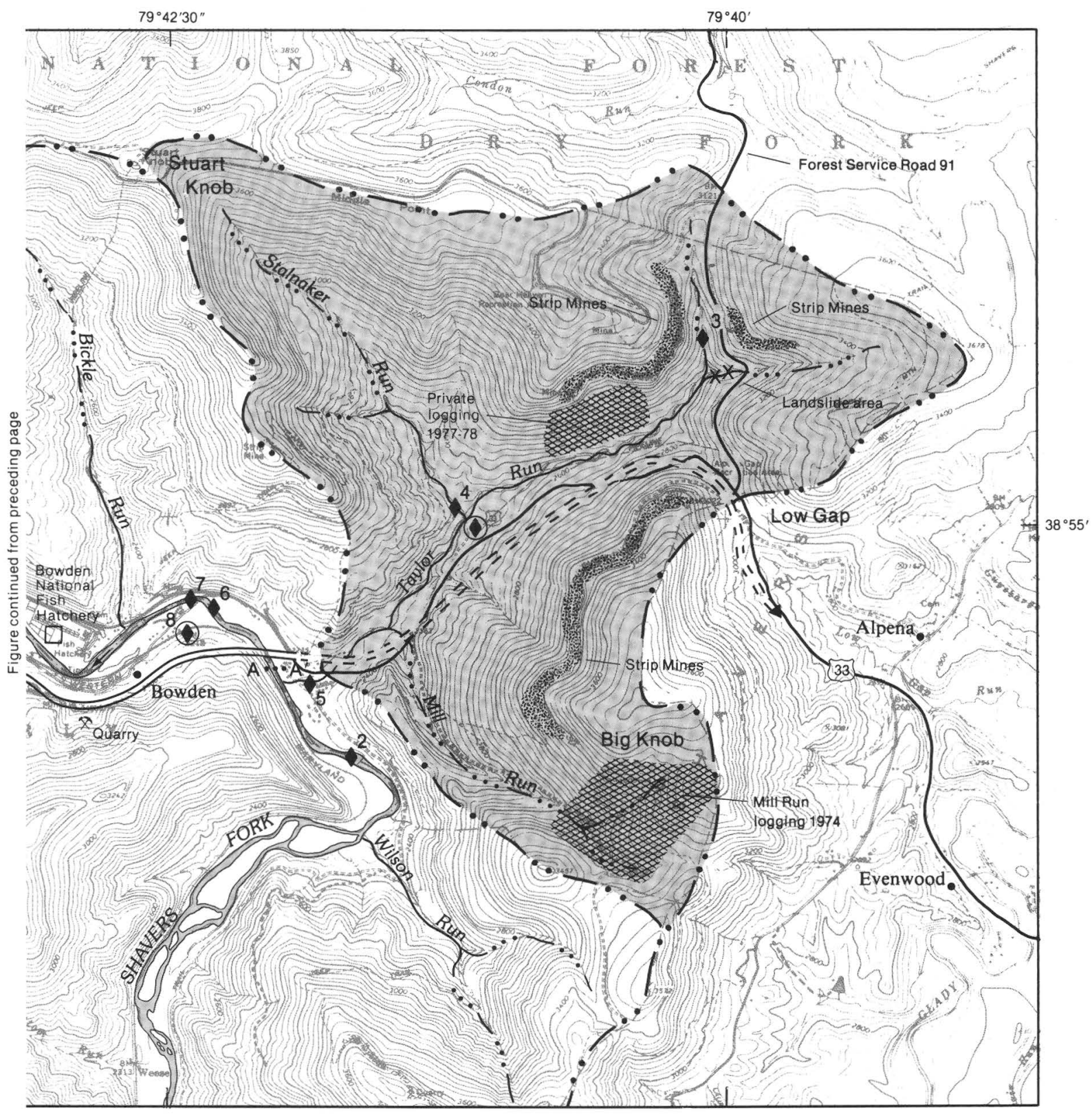




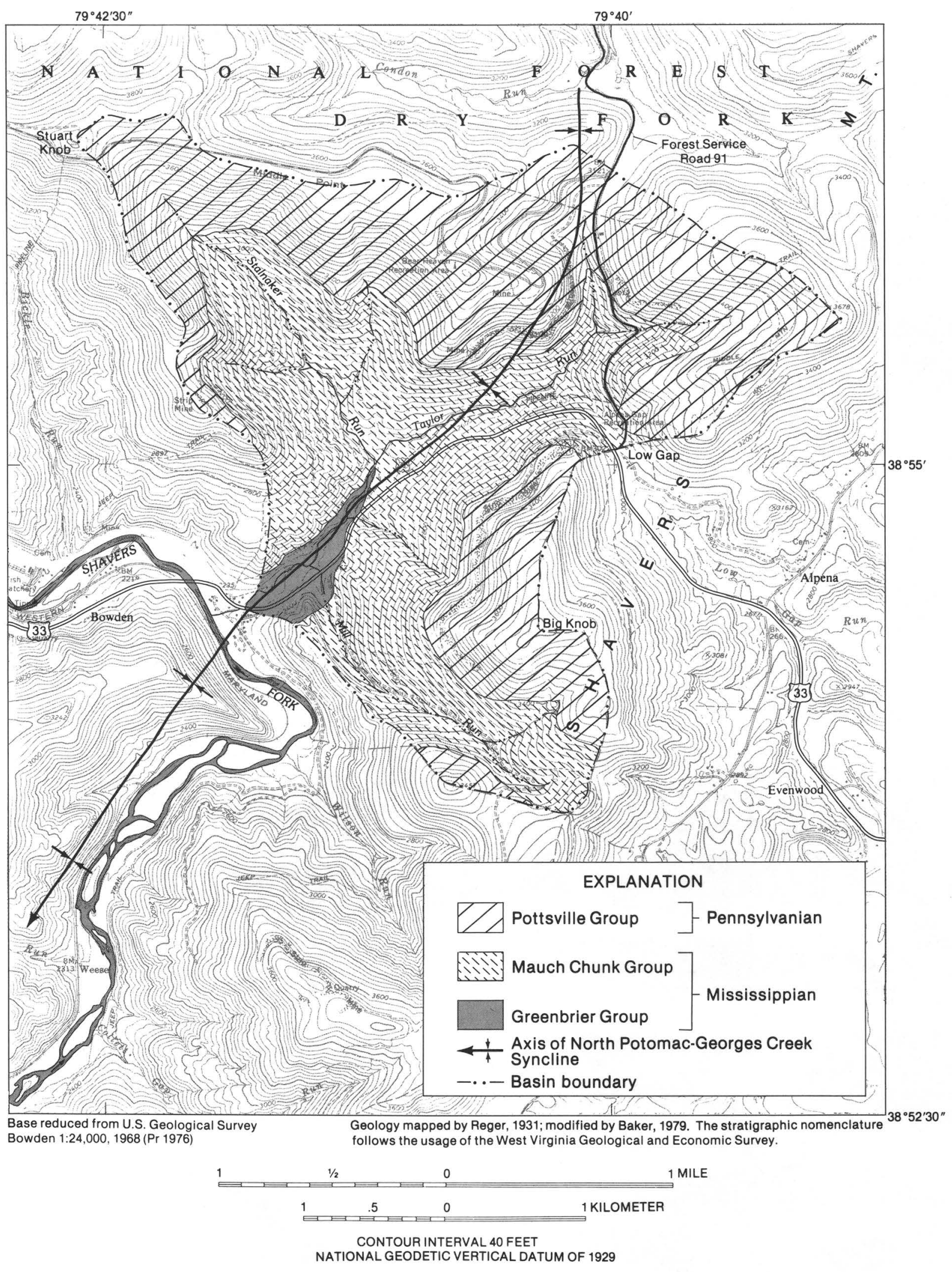

Figure 3. Generalized geology of Taylor Run basin. 
head of the basin downstream to near Bemis (fig. 1). The North Potomac-Georges Creek Syncline crosses Shavers Fork just upstream from the mouth of Taylor Run and roughly parallels the Shavers Fork streambed to the head of the basin.

The geology of the Shavers Fork basin downstream from the mouth of Taylor Run, where the stream bends sharply to the west, varies. Stratigraphy upstream from the lower end of the highway construction zone, from youngest to oldest, is: Quaternary alluvium of the Cenozoic Era, the Pottsville Group of the Pennsylvanian Period, the Mauch Chunk, Greenbrier and Pocono Groups of the Mississippian Period, and the Hampshire Formation of the Devonian Period.

The general geology of the Shavers Fork area is summarized in reports by the West Virginia Geological Survey pertaining to Randolph County (Reger, 1931) and Pocahontas County (Reger, 1929). Geology is shown in detail on Map II of Randolph County (Reger, 1931) and Map II of Pocahontas County (Reger, 1929) and more recently on the 1968 Geologic Map of West Virginia, West Virginia Geological and Economic Survey (Cardwell, Erwin, and Woodward, 1968). The geologic names shown are those used by the West Virginia Geological and Economic Survey and do not necessarily conform to those used by the U.S. Geological Survey.

\section{Cultural Activities}

\section{Taylor Run}

Human activities contributing to sediment production in the Taylor Run study area were minimal during 1975-80. Routine annual road maintenance was done along $2.1 \mathrm{mi}$ of U.S. Route 33, which bisects the basin, and also along $3.6 \mathrm{mi}$ of Forest Service Road 91 (fig. 2), which meanders along the headwater sections of Taylor Run and eventually crosses the uppermost drainage of Stalnaker Run.

Three projects affecting suspended-sediment yield were active in the basin just before or during the study:

1. A project to repair a landslide (fig. 2) above Forest Service Road 91, immediately south of the crossing of the right fork of Taylor Run, was completed in the fall of 1974 . Nearly $5,000 \mathrm{yd}^{3}$ (cubic yards) of material was excavated at this site
(R. C. Trochlil, U.S. Forest Service, written commun., 1981).

2. Approximately 149 acres of timber was logged during 1974 in the Mill Run drainage (fig. 2), southeast of U.S. Route 33. Timber was hauled over a dirt logging road east of and parallel to Mill Run (R. C. Trochlil, U.S. Forest Service, written commun., 1981).

These two projects were concluded just before the beginning of daily-sediment sampling.

3. Approximately 70 acres of timber was logged from a 115 -acre private tract surrounded by national forest near the center of the Taylor Run basin (fig. 2). This operation disturbed soil on about 2 percent of the Taylor Run drainage along the lower and middle north slopes. Logging started in August 1977 and ended in early June 1978 (J. Sloan, logging contractor, oral commun., 1981).

Other soil-disturbing activities in the Taylor Run basin before October 1974 may have a bearing on sediment yields. Seventy-two acres of timber in four units were either clearcut or thinned in the upper half of the Stalnaker Run drainage from 1968 to 1970 . Approximately 115 acres were logged during 1971-72 in the head of Taylor Run on the upper slopes, but most of the timber was hauled down the east side of the mountain toward Glady Fork (fig. 1). Fifty acres were logged in the lower and middle slopes of Taylor Run just east of Stalnaker Run from 1968 to 1970 , of which 34 were clearcut and 16 thinned. The refuse on this 34-acre clearcut was removed in June 1973.

Four strip mines are located in the basin but have been inactive since 1970 or before. Data were not available to differentiate mining-derived sediment yields from the normal annual suspendedsediment yield of the basin.

\section{Shavers Fork}

Human activities disrupting soil and vegetation in the Shavers Fork basin were of a greater magnitude than those in the Taylor Run basin. Soil-disturbing activities along the 5-mi reach between the mouth of Taylor Run and the Shavers Fork below Bowden gage were numerous; these included logging, limestone quarry excavations, and excavation and fill for $5 \mathrm{mi}$ of four-lane highway. These 
activities affected about 900 acres or nearly 18 percent of the Shavers Fork drainage between the upper and lower limits of highway construction (8 $\mathrm{mi}^{2}$ ) shown in figure 2. Clearing of the highway right-of-way in the Shavers Fork drainage began in the fall of 1972; completion of the highway and final cleanup ended in late summer 1976. Highway construction involved a total cleared area of 0.30 $\mathrm{mi}^{2}$ or 192 acres in the Shavers Fork drainage (J. Chenoweth, West Virginia Department of Highways, oral commun., 1981). This represents only 0.2 percent of the total drainage area upstream from the gaging station at Shavers Fork below Bowden.

\section{Climate}

The climate is characterized as continental inland. Warm humid summers and relatively long winters are typical, with prevailing winds from the west and northwest. Temperature and precipitation data obtained from National Oceanic and Atmospheric Administration (NOAA) records from the Elkins airport, $9 \mathrm{mi}$ west of the study area (fig. 1), show average January and July temperature to be $30.0^{\circ} \mathrm{F}\left(-1.0^{\circ} \mathrm{C}\right)$ and $68.7^{\circ} \mathrm{F}\left(20.5^{\circ} \mathrm{C}\right)$, respectively. (U.S. Department of Commerce, National Oceanic and Atmospheric Administration, 1974-1980).

The average frost-free season, from mid-May to mid-September, is about 130 days. Temperature extremes during the 6-year investigation were $91^{\circ} \mathrm{F}$ $\left(33.0^{\circ} \mathrm{C}\right)$ and $-22^{\circ} \mathrm{F}\left(-28.9^{\circ} \mathrm{C}\right)$.

Precipitation was recorded continuously from July 1975 to September 1980 at the South Spring at Bowden gage (site 8) and from October 1978 to September 1980 near the Stalnaker Run gage (site 4). (Rain-gage locations shown in figure 2.) Yearly precipitation totals at the South Spring and Stalnaker Run rain gages and Elkins airport (fig. 1) are compared in figure 4; yearly precipitation at South Spring averaged approximately 6 in. (inches) more than at Elkins airport. The average monthly and annual precipitation measured at Elkins airport from 1941 to 1970 (normal period) is summarized in table 1 . The departure of the monthly and annual precipitation from normal at Elkins airport is graphed in figure 5.

Annual precipitation at Elkins airport was 13.56 in. above normal during 1980 and 7.34 in. below normal during 1976 . The largest monthly departure above normal was 6.38 in. during August
1980 , and the largest monthly departure below normal was 2.93 in. during August 1976.

Storms producing greater than $2.0 \mathrm{in}$. rainfall in 24 hours at South Spring occurred five times from August 1975 to September 1980. The largest of these produced 3.34 in. on July 3, 1980 at the South Spring gage.

\section{DATA COLLECTION}

Collection of hydrologic data in the Taylor Run-Shavers Fork area began in April 1973 and ended in September 1980. Locations of all datacollection sites are shown on the map in figure 2 except Shavers Fork at Bemis and Shavers Fork near Elkins, which are shown in figure 1. Datacollection sites are listed by site number in table 2 .

All suspended-sediment and streamflow data are published annually by the U.S. Geological Survey (1973-80), with the exception of data from the instantaneous pump samplers at Taylor Run near Alpena and Stalnaker Run near Bowden, which are given in Appendix A. Suspended-sediment concentrations, expressed in $\mathrm{mg} / \mathrm{L}$ (milligrams per liter), were determined by the dry-weight method outlined by Guy (1969); and, from the concentrations, the daily suspended-sediment discharge or load (expressed in tons per day), was computed by techniques described by Porterfield (1972).

Water-quality data were collected at each site in the study area. Properties measured were specific conductance, $\mathrm{pH}$, air temperature, water temperature, turbidity, and occasionally dissolved oxygen. Samples for standard complete laboratory analyses and particle-size determinations were collected at some sites. The water-quality data are published annually by the U.S. Geological Survey (1973-80).

Rainfall records for South Spring at Bowden (July 1975 to September 1980) and for Stalnaker Run near Bowden (October 1978 to September 1980) are kept in U.S. Geological Survey files; monthly totals are published in U.S. Geological Survey annual data reports (1975-80). Daily precipitation totals for both sites are given in Appendix B.

Daily flow records and other data for North and South Springs at Bowden are also published annually by the Geological Survey. 


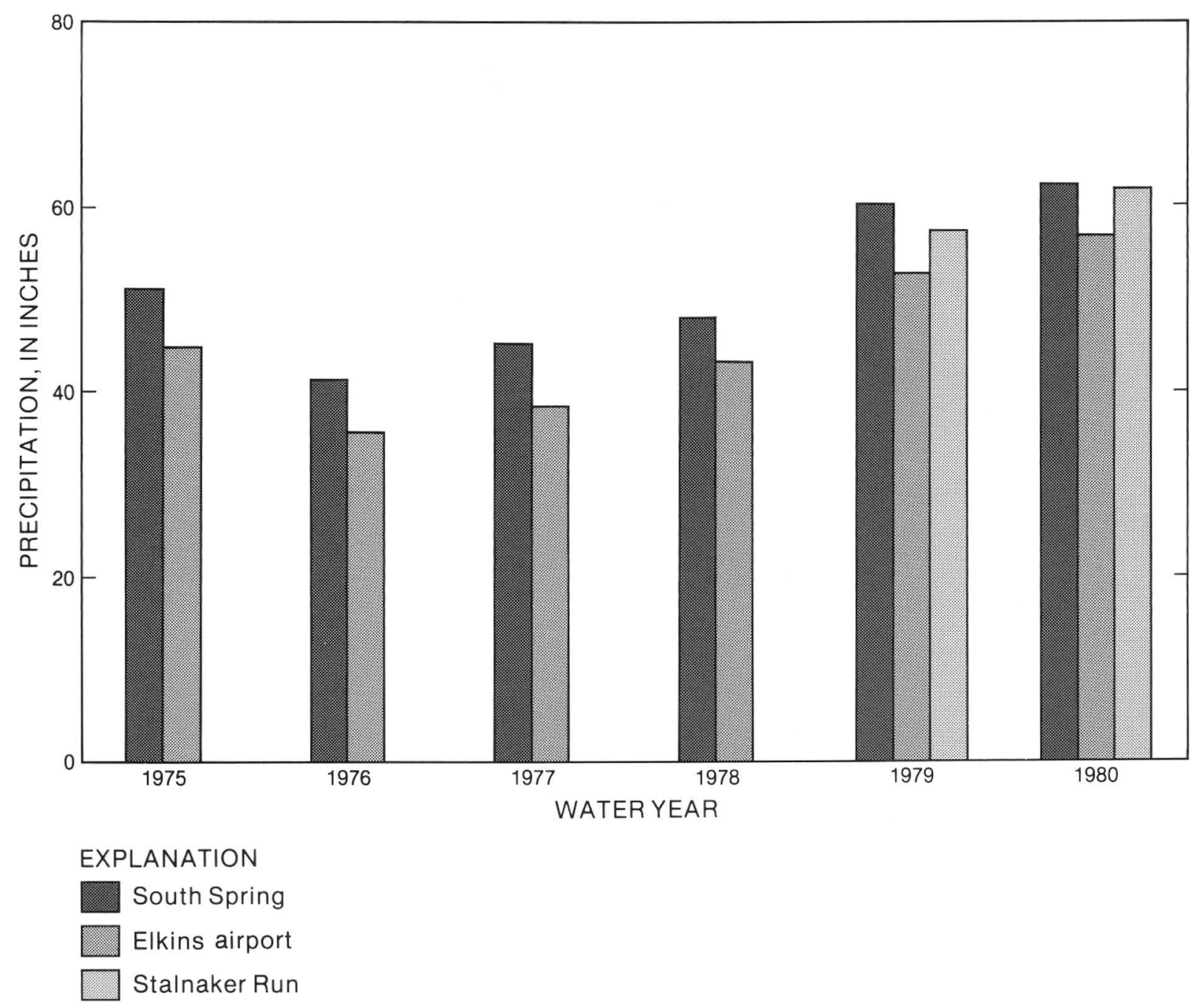

Figure 4. Precipitation by water year, at rain gages at South Spring, Stalnaker Run, and Elkins airport, $1975-80$.

\section{RUNOFF}

Average annual runoff at the Taylor Run at Bowden gage $\left(5.06 \mathrm{mi}^{2}\right)$ was $39.8 \mathrm{in}$. for the 6 -year study period, which includes the 1975-80 water years. Average annual runoff at the Shavers Fork below Bowden gage $\left(151 \mathrm{mi}^{2}\right)$ during the same period was 38.4 in. Precipitation at the South Spring rain gage during the same period averaged 51.5 in. Table 3 gives annual precipitation and runoff at gaging sites in the study area.

About 77 percent of the precipitation on the Taylor Run basin during this 6-year period was discharged as streamflow or surface runoff. The remainder either evaporated, was transpired by vegetation, and (or) possibly lost by seepage through fractured zones of the Greenbrier limestone. Dye tracing, resistivity testing, and core- boring tests show that Taylor Run basin supplies water to local springs and that ground water moves along fissures and joints from the vicinity of Taylor Run toward the North Spring, the major water source for the Bowden National Fish Hatchery (Baker, 1979).

The maximum and minimum monthly runoff at Taylor Run at Bowden during the study period occurred during 1978. The minimum monthly runoff of 0.24 in. was in October 1978, and the maximum monthly runoff of 8.61 in. was in December 1978. The minimum monthly runoff corresponded with the minimum monthly suspended-sediment discharge. The maximum monthly runoff did not correspond with the maximum monthly suspendedsediment discharge owing to basin disturbances, rainfall intensity, and other factors. 
Table 1. Monthly and annual precipitation at Elkins airport during 1941-70 (normal period).

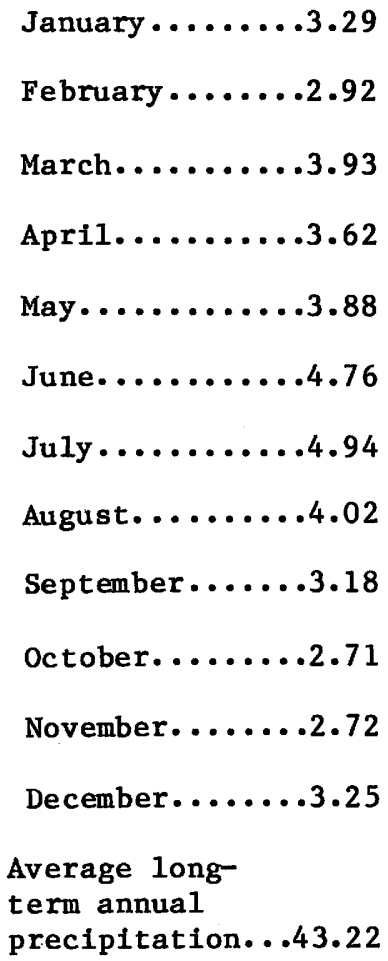

The minimum monthly runoff at Shavers Fork below Bowden during the study ( 0.33 in.) was in October 1978; the maximum monthly runoff $\mathbf{( 7 . 6 3}$ in.) was in March 1975. The minimum monthly runoff did not correspond with the minimum monthly suspended-sediment discharge. The maximum monthly runoff occurred before the start of daily suspended-sediment record in June 1975.

\section{SUSPENDED-SEDIMENT YIELD}

\section{Taylor Run}

Suspended-sediment loads and yields at the Taylor Run at Bowden site $\left(5.06 \mathrm{mi}^{2}\right)$ were computed on a daily basis from October 1974 to September 1980. Yields are summarized in table 4; figure 6 is a graph of the cumulative monthly suspended-sediment discharge plotted against cumulative monthly streamflow. As can be seen in figure 6, the relationship between yield and streamflow remained constant during 1975-77. During 1978, however, suspended-sediment yields more than doubled from the previous year. The new relationship between suspended-sediment yield and streamflow remained relatively constant during 1979 and 1980. The increase in sediment yield corresponds to a logging operation in the basin from August 1977 to June 1978.

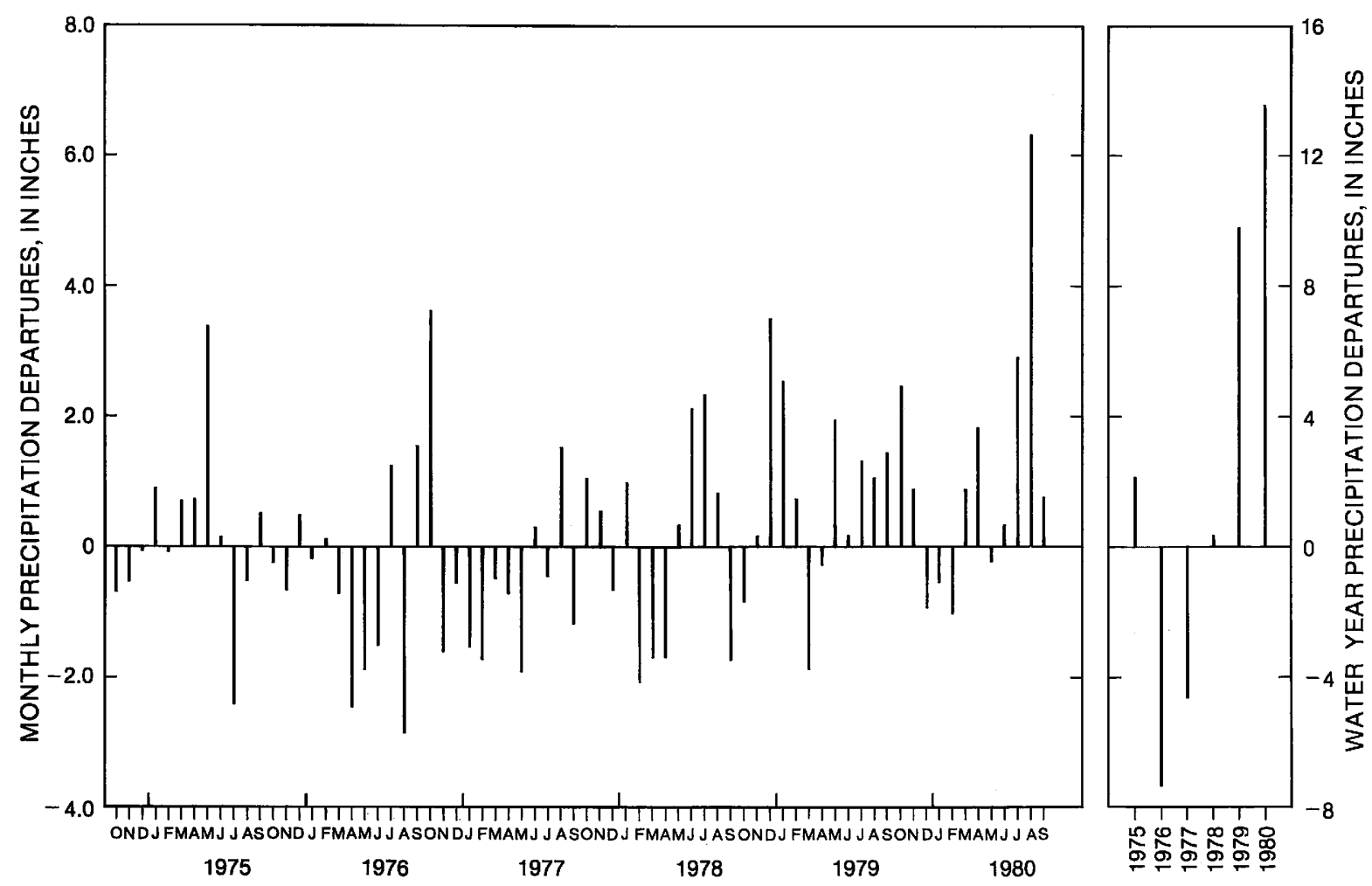

Figure 5. Departure of monthly and water-year precipitation from normal at Elkins airport, 1975-80. 
The period of the logging operation is also shown in figure 6 . The data in figure 6 can generally be divided into two straight-line segments--from October 1974 to September 1977 and October 1977 to September 1980. Suspended-sediment yields averaged about 41 (tons $/ \mathrm{mi}^{2}$ )/year (tons per square mile per year) the first 3 years and 114 (tons $/ \mathrm{mi}^{2}$ ) $/$ year the last 3 years. Annual streamflow averaged $945 \mathrm{ft}^{3} / \mathrm{s}-\mathrm{d}$ (cubic feet per seconddays) the first 3 years and $1,194 \mathrm{ft}^{3} / \mathrm{s}-\mathrm{d}$ the last 3 years. The average suspended-sediment concentration from October 1974 to September 1977 was 15.9 $\mathrm{mg} / \mathrm{L}$, and the average concentration from October 1977 to September 1980 was $35.3 \mathrm{mg} / \mathrm{L}$. Two factors--higher precipitation and logging--are probably the cause of the higher suspended-sediment yields and concentrations.

The maximum daily suspended-sediment load, 162 tons, and instantaneous streamflow, $302 \mathrm{ft}^{3} / \mathrm{s}$ (cubic feet per second), over the study period occurred on July 3, 1980 (table 5). Suspended sedi- ment discharged during this storm was 23 percent of the total suspended-sediment load for 1980. Precipitation at the Stalnaker Run rain gage (fig. 2) totaled 3.30 in. on July 3, 1980 with a maximum hourly precipitation of 1.38 in. Precipitation at the South Spring rain gage (fig. 2) totaled 3.34 in. on July 3,1980 with a maximum hourly precipitation of $2.07 \mathrm{in}$. The mean suspended-sediment concentration associated with this storm was $638 \mathrm{mg} / \mathrm{L}$, as shown in figure 7 .

The second greatest instantaneous streamflow during the study, $255 \mathrm{ft}^{3} / \mathrm{s}$, occurred on July 3, 1978. The daily suspended-sediment load, 140 tons, during the storm was 27 percent of the total load for 1978. Precipitation at the South Spring rain gage totaled 2.51 in. on July 3, 1978, with a maximum hourly precipitation of 0.73 in. The mean suspended-sediment concentration associated with this storm was $376 \mathrm{mg} / \mathrm{L}$.

Another large storm occurred on June 1, 1974, before the beginning of daily suspended-sediment sample collection. The maximum instantaneous

Table 2. Data-collection sites within Taylor Run-Shavers Fork study area.

\begin{tabular}{|c|c|c|c|c|c|c|c|}
\hline \multirow{2}{*}{$\begin{array}{l}\text { Site } \\
\text { No. } \\
1\end{array}$} & $\begin{array}{l}\text { Station } \\
\text { No. }\end{array}$ & Station Name & \multirow{2}{*}{$\begin{array}{c}\begin{array}{c}\text { Drainage } \\
\text { area, in } \\
\text { square } \\
\text { miles }\end{array} \\
115\end{array}$} & $\begin{array}{l}\text { Period of } \\
\text { record } \\
\text { (water years) } 1 /\end{array}$ & $\begin{array}{l}\text { Type } \\
\text { of data }\end{array}$ & $\begin{array}{l}\text { Period of } \\
\text { record } \\
\text { (water years) }\end{array}$ & $\begin{array}{l}\text { Type of } \\
\text { data }\end{array}$ \\
\hline & 03068000 & Shavers Fork at Bemis & & $1974-79$ & Daily. & $1973-79$ & Intermittent. \\
\hline 2 & 03068600 & Shavers Fork above Bowden & 138 & $\begin{array}{l}1973-75 \\
1976-80\end{array}$ & $\begin{array}{l}\text { Intermittent. } \\
\text { Daily. }\end{array}$ & $\begin{array}{l}1973-75 \\
1976-80\end{array}$ & $\begin{array}{l}\text { Do. } \\
\text { Daily. }\end{array}$ \\
\hline 3 & 03068604 & Taylor Run near Alpena & 1.06 & 1979,80 & Do. & 1979,80 & $\begin{array}{l}\text { Intermittent. } 2 \text { / } \\
\text { Storm Samples. }\end{array}$ \\
\hline 4 & 03068607 & Stalnaker Run near Bowden ${ }^{3 /}$ & 1.55 & 1979,80 & Do. & 1979,80 & $\begin{array}{l}\text { Intermittent. } 2 / \\
\text { Storm samples. }\end{array}$ \\
\hline 5 & 03068610 & Taylor Run at Bowden & 5.06 & $\begin{array}{l}1973 \text { partial } \\
1974-\end{array}$ & Do. & $\begin{array}{l}1973,74 \\
1975-80\end{array}$ & $\begin{array}{l}\text { Intermittent. } \\
\text { Daily. }\end{array}$ \\
\hline 6 & 03068690 & North Spring at Bowden & -- & $\begin{array}{l}1975 \text { partial } \\
1976-\end{array}$ & Do. & -- & --- \\
\hline 7 & 03068700 & Shavers Fork at Bowden & 143 & 1973,74 & Inte rmit tent. & 1973,74 & Intermittent. \\
\hline 8 & 03068710 & South Spring at Bowden $4 /$ & -- & $\begin{array}{l}1975 \text { partial } \\
1976-80\end{array}$ & Daily. & --- & $\rightarrow$ \\
\hline 9 & 03068800 & Shavers Fork below Bowden & 151 & $\begin{array}{l}1973 \text { partial } \\
1974-80\end{array}$ & Do. & $\begin{array}{l}1973-75 \\
1976-80\end{array}$ & $\begin{array}{l}\text { Do. } \\
\text { Daily. }\end{array}$ \\
\hline 10 & 03068900 & Shavers Fork near Elkins & 161 & $1973-80$ & Intermittent. & $1973-80$ & Intermittent. \\
\hline & $\begin{array}{l}\text { Water } \\
\text { Storm } \\
\text { Recor } \\
\text { Recor }\end{array}$ & $\begin{array}{l}\text { ar is the period from Octobe } \\
\text { noff samples were collected } \\
\text { g precipitation gage Octobe } \\
\text { g precipitation gage July }\end{array}$ & $\begin{array}{l}15-\text { minu } \\
1978 \text { to } s \\
5 \text { to Sept }\end{array}$ & $\begin{array}{l}\text { us calendar ye } \\
\text { intervals. } \\
\text { ember } 1980 \text {. } \\
\text { ex } 1980 .\end{array}$ & to Sep & & er water year \\
\hline
\end{tabular}


Table 3. Annual precipitation and runoff, in inches, for gaging sites in the study area.

\begin{tabular}{|c|c|c|c|c|c|c|}
\hline \multirow[b]{2}{*}{ Water year } & \multicolumn{2}{|c|}{ Precipitation } & \multicolumn{4}{|c|}{ Runoff } \\
\hline & $\begin{array}{c}\text { South Spring } \\
\text { Site } 8 \\
\end{array}$ & $\begin{array}{c}\text { Stalnaker Run } \\
\text { Site } 4 \\
\end{array}$ & $\begin{array}{l}\text { Taylor Run } \\
\text { at Bowden } \\
\text { Site } 5 \\
\end{array}$ & $\begin{array}{l}\text { Taylor Run } \\
\text { near Alpena } \\
\text { Site } 3 \\
\end{array}$ & $\begin{array}{c}\text { Stalnaker Run } \\
\text { near Bowden } \\
\text { Site } 4 \\
\end{array}$ & $\begin{array}{c}\text { Shavers Fork } \\
\text { below Bowden } \\
\text { Site } 9 \\
\end{array}$ \\
\hline 1975 & $* 51.00$ & --- & 45.35 & -- & -- & 44.45 \\
\hline 1976 & 41.31 & --- & 26.28 & -- & -- & 28.94 \\
\hline 1977 & 45.31 & -- & 33.84 & -- & --- & 34.91 \\
\hline 1978 & 48.34 & -- & 42.79 & -- & -- & 38.33 \\
\hline 1979 & 60.34 & 57.41 & 44.41 & 40.53 & 45.08 & 42.56 \\
\hline 1980 & 62.53 & 62.16 & 46.08 & 45.15 & 44.20 & 41.34 \\
\hline
\end{tabular}

* Estimated from partial record and nearby National Oceanic and Atmospheric Administration (NOAA) precipitationobservation sites.

Table 4. Annual suspended-sediment discharge and streamflow at the Taylor Run at Bowden gage, water years 1975-80.

\begin{tabular}{|c|c|c|c|c|}
\hline \multirow[b]{2}{*}{ Water year } & \multicolumn{2}{|c|}{ Suspended-sediment discharge } & \multicolumn{2}{|c|}{ Streamflow } \\
\hline & $\begin{array}{l}\text { Load } \\
\text { (tons) }\end{array}$ & $\begin{array}{c}\text { Yield } \\
\left(\text { tons/mi } / \mathrm{mi}^{2}\right)\end{array}$ & $\left(f t^{3} / s-d\right)$ & {$\left[\left(\mathrm{ft} \mathrm{t}^{3} / \mathrm{s}-\mathrm{d}\right) / \mathrm{mi}^{2}\right]$} \\
\hline 1975 & 248.31 & 49.07 & $6,169.24$ & $1,219.22$ \\
\hline 1976 & 115.76 & 22.88 & $3,574.86$ & 706.49 \\
\hline 1977 & 251.51 & 49.71 & $4,603.70$ & 909.82 \\
\hline 1978 & 527.02 & 104.15 & $5,821.08$ & $1,150.41$ \\
\hline 1979 & 495.27 & 97.88 & $6,042.12$ & $1,194.09$ \\
\hline 1980 & 705.88 & 139.50 & $6,268.70$ & $1,238.87$ \\
\hline Total & $2,343.75$ & -- & $32,479.70$ & -- \\
\hline Average & 390.62 & -- & $5,413.28$ & -- \\
\hline
\end{tabular}




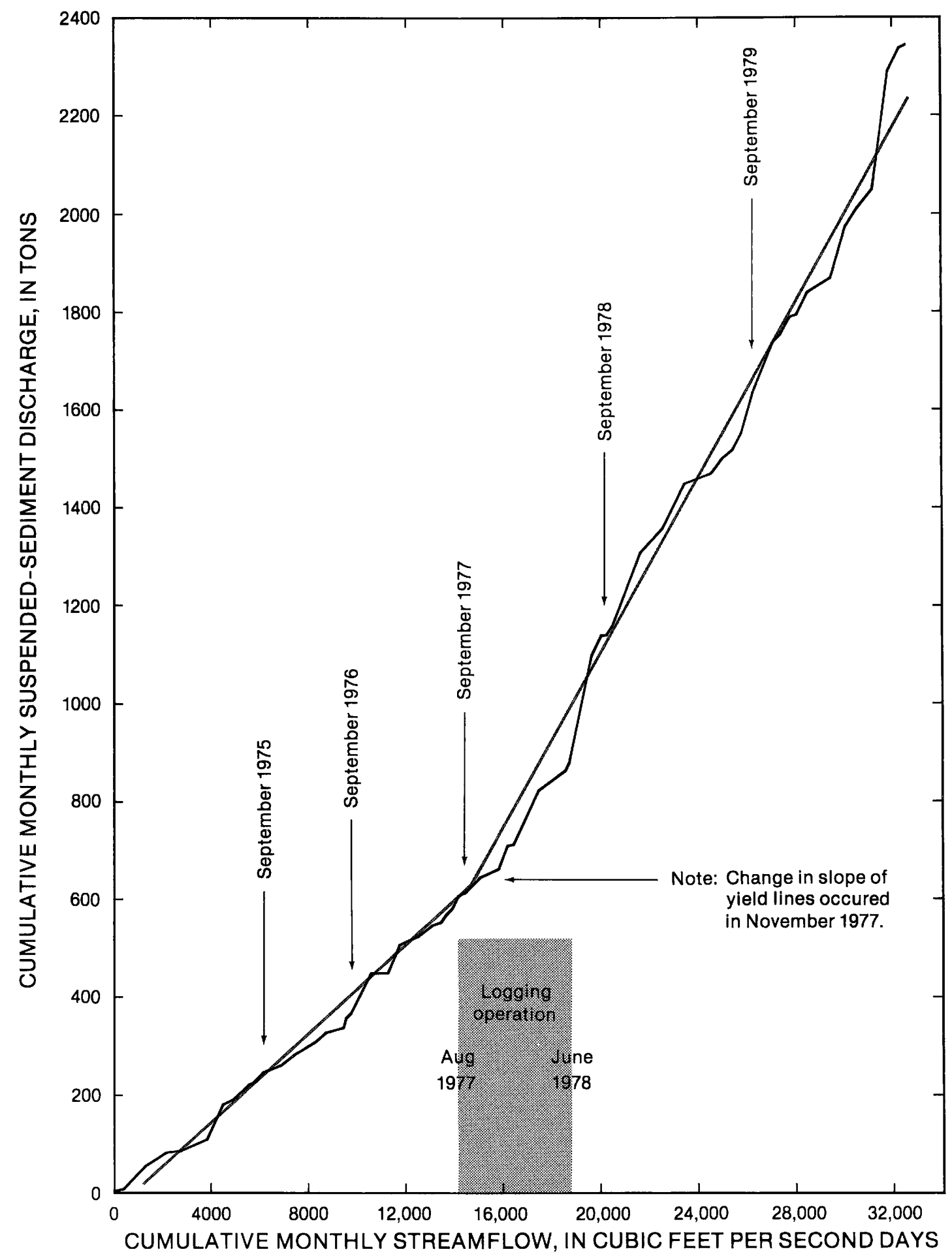

Figure 6. Cumulative monthly suspended-sediment discharge and streamflow from Taylor Run, October 1974-September 1980. 
streamflow associated with this storm was $208 \mathrm{ft}^{3} / \mathrm{s}$, and the computed daily-suspended sediment load was 92 tons. Estimated daily precipitation was 1.75 in. and no hourly precipitation data are available. The mean suspended-sediment concentration associated with this storm was $321 \mathrm{mg} / \mathrm{L}$; this may reflect logging activities in the Mill Run drainage (fig. 2). This and other June 1974 storms probably caused the slide above Forest Service Road 91 in the upper reaches of the Taylor Run drainage.

The storms in July 1978 and July 1980 caused abrupt rises in the cumulative suspended-sediment discharge and streamflow plot (fig. 6). The storm on July 3, 1978 occurred immediately after the completion of an 11-month logging project near the center of the basin. Runoff from this storm probably washed loosened soil out of the basin. Suspendedsediment yield during the intense storm of July 3, 1980 could not be directly related to recent activities of man in the basin. This high yield was probably associated with rainfall intensity because rainfall from a convective storm generally has considerable kinetic energy that may cause soil erosion and high sediment yields. Five major storms with rainfall greater than $2.0 \mathrm{in}$. within 24 hours at South Spring occurred from August 1975 to September 1980 and produced runoff that carried nearly 20 percent of the total suspended-sediment load for the 6-year study period.

The annual suspended-sediment yield for the study period (tons per square mile) is plotted in figure 8. The pattern coincides with that of annual precipitation during the study (fig. 4) except that the sediment discharge in 1978 and 1980 is high as a result of major storms. Suspended-sediment yields from the storms on July 3, 1978 and July 3, 1980 accounted for nearly 14 percent of the 6-year total suspended-sediment load.

Suspended-sediment regression curves for each water year (1975-80) are shown in figure 9. The slope of any single curve is not significantly different from any other, which indicates no major change in the relationship between suspendedsediment load and streamflow, as would be expected from a major land disturbance. The relatively small differences in slope were probably the result of annual precipitation variation.

\section{Upper Taylor Run}

The streamflow-gaging stations in the upper part of the Taylor Run basin at Stalnaker Run near Bowden and Taylor Run near Alpena (fig. 2) began operating October 1978. Automatic pump samplers were installed at these stations to obtain water samples during storm runoff. About 52 percent of the Taylor Run drainage area lies upstream from these two stations, and the logging operation from 1977-78 was downstream from these stations.

The maximum daily suspended-sediment yield at both stations was on July 3,1980. Maximum concentrations sampled at Stalnaker Run near Bowden were in excess of $5,000 \mathrm{mg} / \mathrm{L}$ and at Taylor Run near Alpena in excess of 7,000 mg/L. Logging in the Stalnaker Run basin ceased in the summer of 1970 and in the upper Taylor Run basin in 1972. The repair of the slide above Forest Service Road 91 was completed in the fall of 1974 . There have been

Table 5. Data for three major storms in the Taylor Run basin, 1974-80.

\begin{tabular}{|c|c|c|c|c|c|c|c|}
\hline \multirow[b]{2}{*}{ Date } & \multicolumn{2}{|c|}{$\begin{array}{c}\text { Dafly suspended- } \\
\text { sediment yield }\end{array}$} & \multirow{2}{*}{$\begin{array}{l}\text { Instan- } \\
\text { taneous } \\
\text { discharge } \\
\left(\mathrm{ft}^{3} / \mathrm{s}\right)\end{array}$} & \multirow{2}{*}{$\begin{array}{l}\text { Mean daily } \\
\text { discharge } \\
\left(\mathrm{ft}^{3} / \mathrm{s}\right)\end{array}$} & \multirow{2}{*}{$\begin{array}{l}\text { Runoff } \\
\text { (Inches) }\end{array}$} & \multirow{2}{*}{$\begin{array}{l}\text { Daily pre- } \\
\text { cipitation } \\
\text { (inches) }\end{array}$} & \multirow{2}{*}{$\begin{array}{l}\text { Maximum } \\
\text { hourly pre- } \\
\text { cipitation } \\
\text { (inches) }\end{array}$} \\
\hline & (tons) & (tons/mi $\left.{ }^{2}\right)$ & & & & & \\
\hline June 1,1974 & 92 & 18.2 & 208 & 106 & 0.78 & $* 1.75$ & -- \\
\hline July 3, 1978 & 140 & 27.7 & 255 & 138 & 1.01 & $* * 2.511 /$ & $* * 0.73$ \\
\hline July 3,1980 & 162 & 32.0 & 302 & 94 & .69 & $* * 3.34$ & $* * 2.07$ \\
\hline
\end{tabular}

* Estimated from Elkins Airport and records of other nearby NOAA precipitation observers.

** From South Spring rain gage.

1/ Total precipitation during the storm of July 2-3, 1978 was 3.73 in. 
no mining activities since at least 1970 in the upper Taylor Run basin. Thus, these suspended-sediment concentrations and corresponding yields were directly related to rainfall intensity.

A general relation usually exists between streamflow and particle-size distribution of the suspended sediment. As flow increases, velocity generally increases, and the stream is able to transport larger particles. Consequently, the percentage of suspended sediment composed of sand [particles with diameters between 0.062 and $2.0 \mathrm{~mm}$ (millimeters)] would increase, and the percentage of suspended sediment composed of silt (particles with diameters between 0.004 and $0.062 \mathrm{~mm}$ ) and clay (particles with diameters less than $0.004 \mathrm{~mm}$ ) would decrease (Reed 1978).

Usually the first storms after the land is disturbed will erode and transport large quantities of fine (silt and clay) particles. The larger sand particles eroded by rain or by overland runoff are usually deposited in the stream channel near the point of erosion. Later storms continue to erode fine particles and lift the heavier sand particles and redeposit them farther downstream. If the surface soils are not reworked to expose new sources of fine sediments, the surface soils become armored with the remaining large particles. When this happens, fewer fine particles will be available for transport, and sand particles will represent a greater percentage of the suspended load (Yorke and Herb, 1978).

Particle-size analyses of selected individual storm samples collected in the 1979 and 1980 water years at Stalnaker Run near Bowden and Taylor Run near Alpena have been published by the U.S. Geological Survey $(1979,1980)$.

\section{Shavers Fork}

Suspended-sediment loads and yields at the Shavers Fork below Bowden site $\left(151 \mathrm{mi}^{2}\right)$ were computed on a daily basis from June 1975 to September 1980. Table 6 summarizes the annual suspended-sediment discharge and streamflow for the 1976-80 water years.

Suspended-sediment discharge increased markedly from 1976 to 1977 . Suspended-sediment discharge dropped in 1978 and then increased in 1979 and 1980. During 1976-79, streamflow increased each year in the basin but decreased slightly in 1980 .
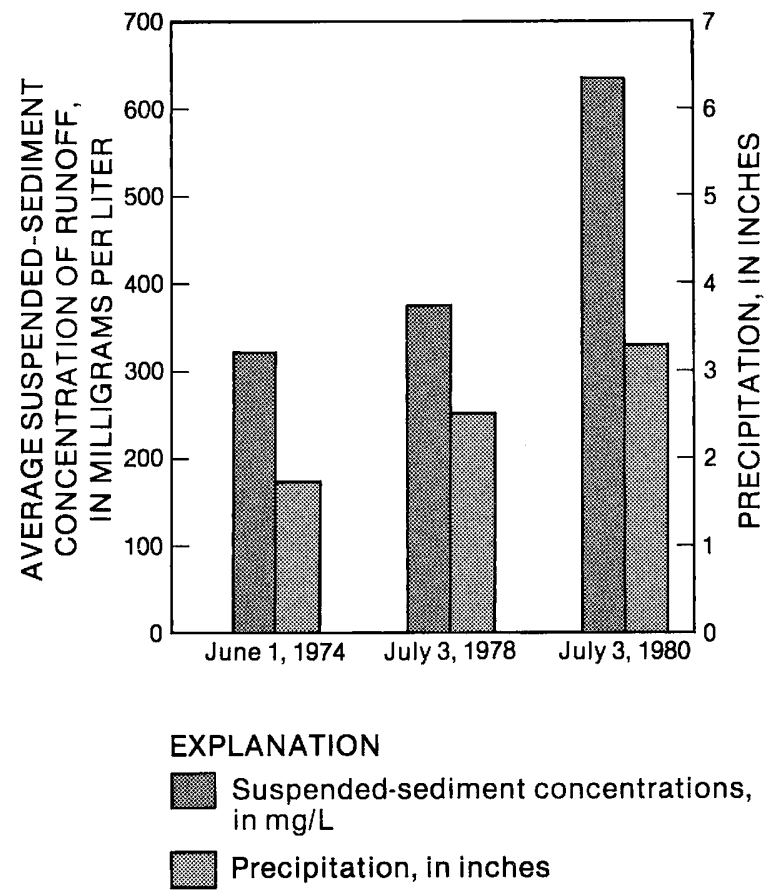

Figure 7. Suspended-sediment concentrations and precipitation data for storms in Taylor Run, June 1, 1974, July 3, 1978, and July 3, 1980.

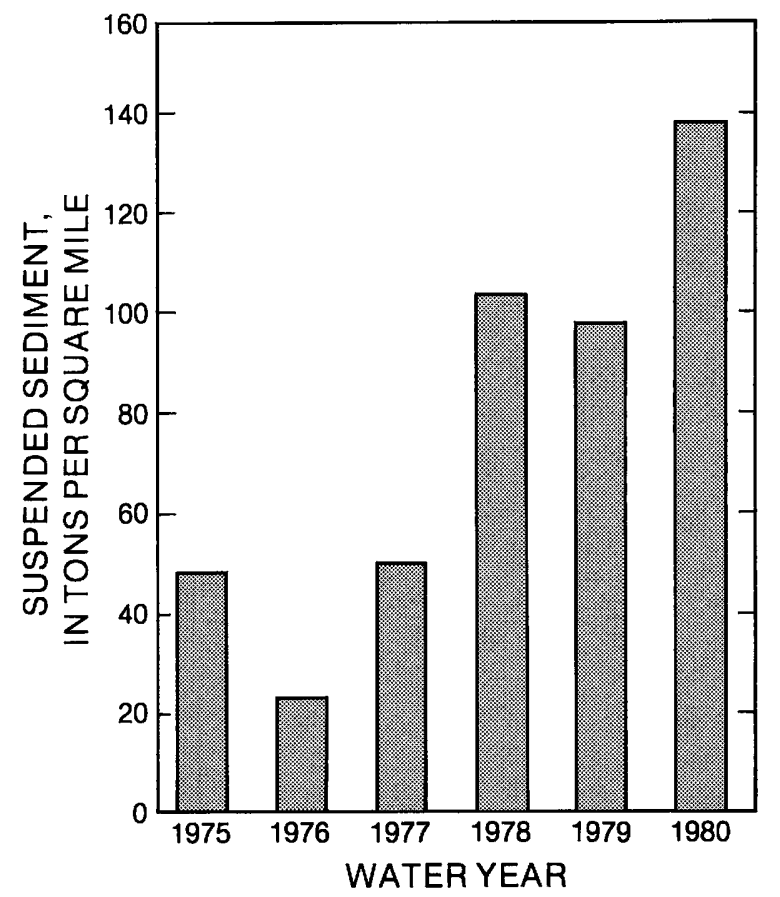

Figure 8. Annual suspended-sediment yield at Taylor Run at Bowden, water years 1975-80. 


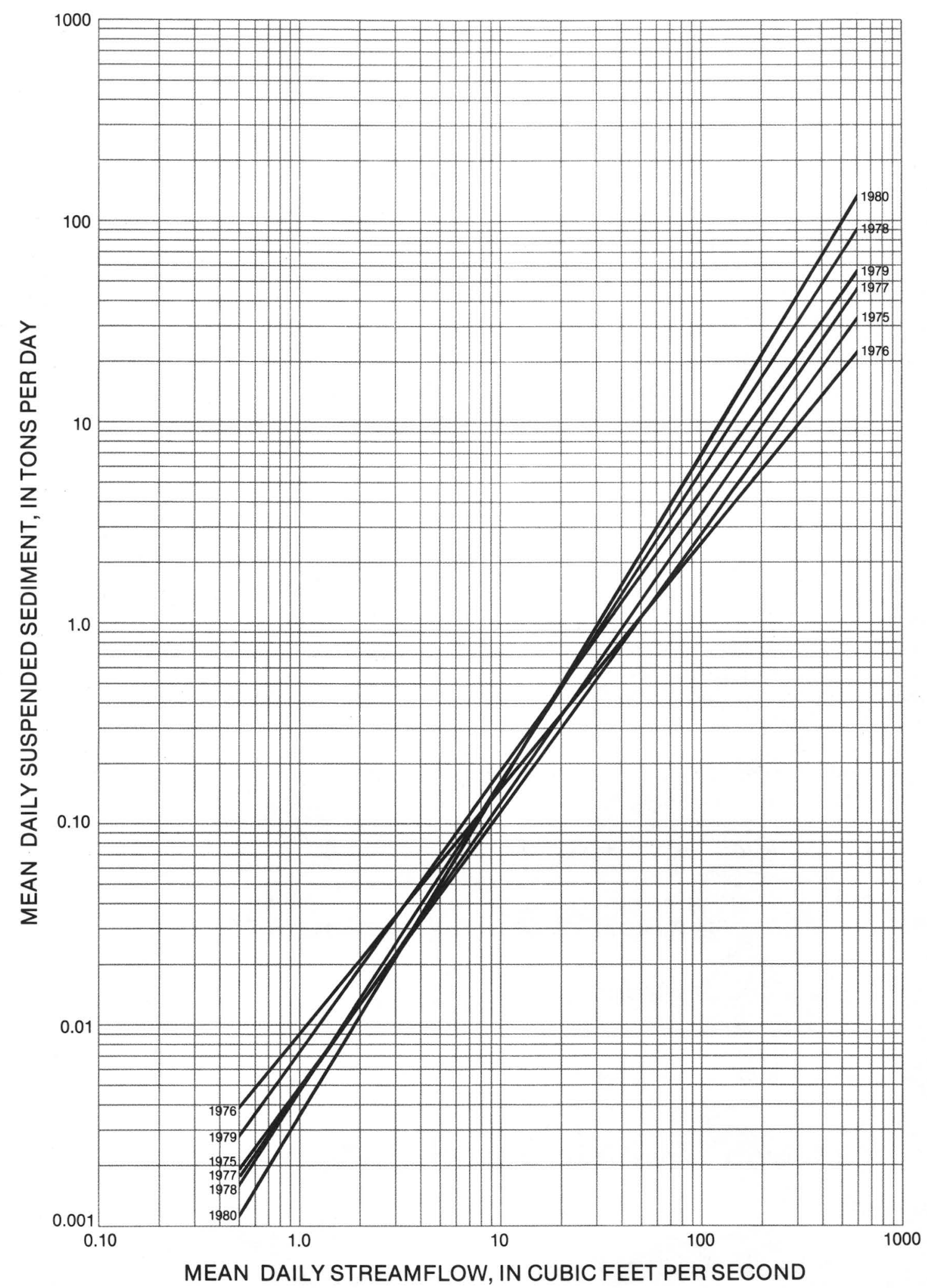

Figure 9. Regression curves of suspended-sediment load versus streamflow at Taylor Run at Bowden, 1975-1980 water years. 
Table 6. Annual suspended-sediment discharge and streamflow at the Shavers Fork below Bowden gage, water years 1976-80.

\begin{tabular}{|c|c|c|c|c|}
\hline \multirow[b]{2}{*}{ Water year } & \multicolumn{2}{|c|}{ Suspended-sediment discharge } & \multicolumn{2}{|c|}{ Streamflow } \\
\hline & $\begin{array}{l}\text { Load } \\
\text { (tons) }\end{array}$ & $\begin{array}{c}\text { Yield } \\
\left.\text { (tons/mi } /{ }^{2}\right)\end{array}$ & $\left(f t^{3} / s-d\right)$ & {$\left[\left(\mathrm{ft}^{3} / \mathrm{s}-\mathrm{d}\right) / \mathrm{mi}^{2}\right]$} \\
\hline 1976 & 5,838 & 38.7 & 117,492 & 778.1 \\
\hline 1977 & 30,767 & 203.8 & 141,689 & 938.3 \\
\hline 1978 & 23,223 & 153.8 & 155,593 & $1,030.4$ \\
\hline 1979 & 25,479 & 168.7 & 172,744 & $1,144.0$ \\
\hline 1980 & 26,412 & 174.9 & 167,789 & $1,111.2$ \\
\hline Total & 111,719 & -- & 755,307 & -- \\
\hline Average & 22,343 & -- & 151,061 & -- \\
\hline
\end{tabular}

A decrease in 1980 also occurred at sites at Shavers Fork above Bowden, Stalnaker Run near Bowden, and South Spring at Bowden. The largest increase in streamflow, 20.6 percent, occurred between 1976 and 1977. The corresponding suspended-sediment load for 1977 was more than five times the load of the previous year.

A graph of the cumulative monthly suspendedsediment discharge plotted against cumulative monthly streamflow for Shavers Fork below Bowden for the period of record (1975-80) is given in figure 10. The last month of each water year is labeled on the graph. The final cleanup for the highway construction was in the late summer of 1976, and suspended-sediment discharge per unit runoff was very high during October 1976 to April 1977. Figure 10 also shows that the relationship of suspended sediment to streamflow was fairly constant from the fall of 1977 to 1980 , which indicates no major changes.

The maximum daily suspended-sediment load, 16,300 tons, and instantaneous streamflow, 12,400 $\mathrm{ft}^{3} / \mathrm{s}$, during the study was on March 13,1977 , the first spring after completion of the highway. The suspended-sediment load from this storm was nearly 53 percent of the total load for 1977 . Precipitation on March 12-13, 1977, was 1.15 in. at the South Spring rain gage and 2.63 in. at Snowshoe (fig. 1). An increase in runoff due to snow melt was ob- served March 13, 1977 by the author. The suspended-sediment load on March 13, 1977, was probably increased as the result of highway construction completed in the previous year. The daily suspended-sediment load of March 13, 1977, at Shavers Fork above Bowden was 16 tons $/ \mathrm{mi}^{2}$, compared with 108 tons $/ \mathrm{mi}^{2}$ at the Shavers Fork below Bowden site. The daily suspended-sediment load on March 13, 1977, at the Taylor Run gaging site (immediately above the construction area and which probably received about $1.0 \mathrm{in}$. of rain) was about 2 tons $/ \mathrm{mi}^{2}$. The intervening drainage $\left(8 \mathrm{mi}^{2}\right)$ from the mouth of Taylor Run to the Shavers Fork below Bowden gage (including the construction area) contributed a daily suspended-sediment load of 1,760 tons $/ \mathrm{mi}^{2}$.

The second largest instantaneous streamflow $\left(11,800 \mathrm{ft}^{3} / \mathrm{s}\right)$ during the study was on October 9 , 1976, just after the cleanup and completion of the highway. This storm carried the third largest daily suspended-sediment load $(6,620$ tons) of the study period. The suspended-sediment load from this storm was 22 percent of the annual load. Precipitation at the South Spring rain gage was 1.93 in. on October 9 and 3.62 in. during the period October 7-10 and seemed to be uniform throughout the basin. The suspended-sediment load at Shavers Fork above Bowden during the period October 7-10 was 42 tons $/ \mathrm{mi}^{2}$, compared with 47 tons $/ \mathrm{mi}^{2}$ for Shavers Fork below Bowden. The suspended- 


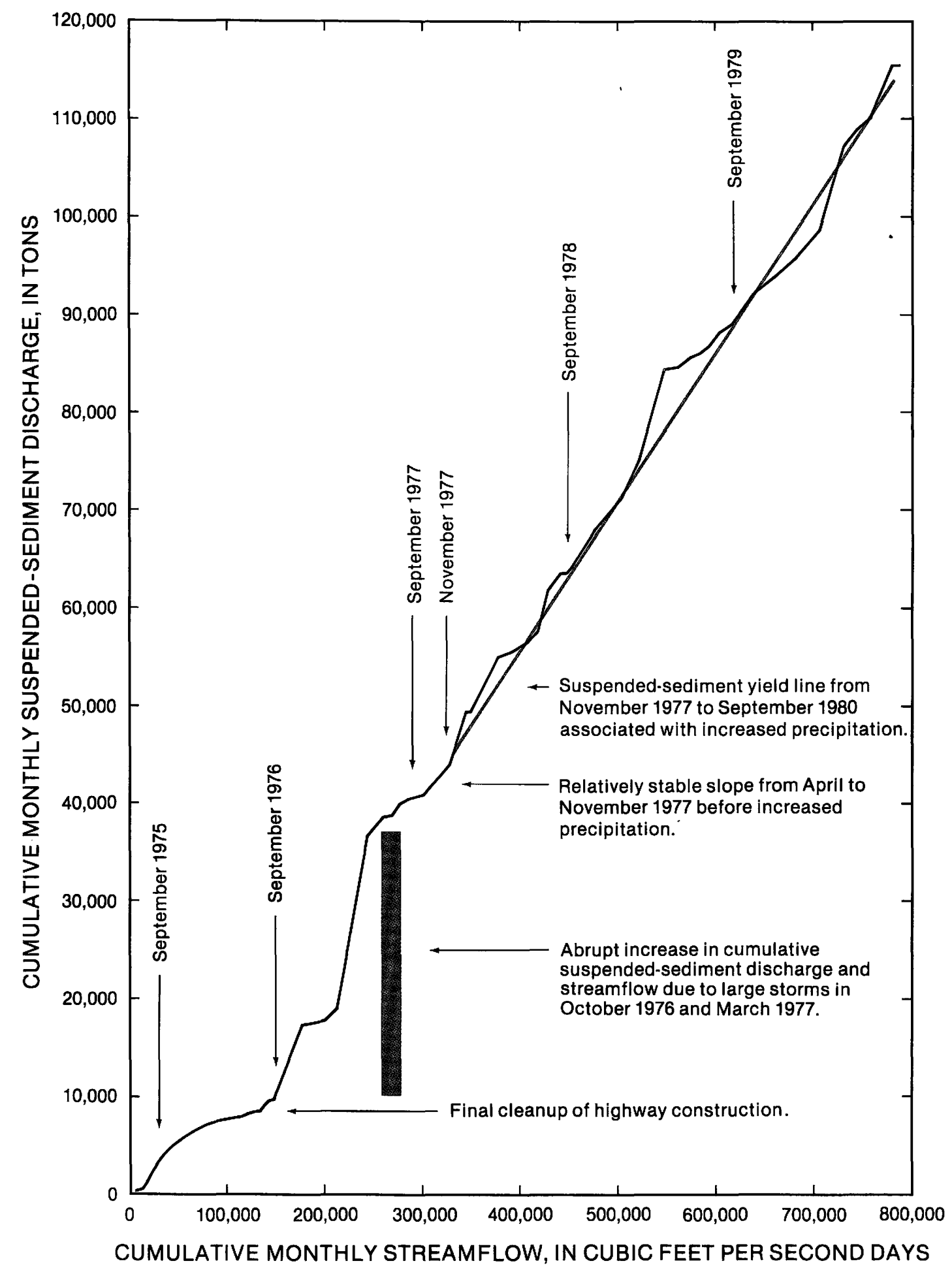

Figure 10. Cumulative monthly suspended-sediment discharge and streamflow at Shavers Fork below Bowden, June 1975 to September 1980. 
sediment load during the period October 7-10 at Taylor Run was 14 tons $/ \mathrm{mi}^{2}$. The suspendedsediment load from the intervening drainage from the mouth of Taylor Run to the Shavers Fork below Bowden gage (including the construction area) was about 150 tons $/ \mathrm{mi}^{2}$.

The storms of October 9, 1976 and March 13, 1977 , accounted for 75 percent of the annual suspended-sediment load for 1977. Suspended sediment from these two storms cause the abrupt jump on the cumulative plot (fig. 10).

Other significant storms occurred on January 26, 1978, March 26, 1978, March 5, 1979, and April 9,1980 . Runoff for the $1978-80$ water years (table 6) ranged from 38.33 to 42.56 in., and suspendedsediment yields ranged from 154 to 175 tons $/ \mathrm{mi}^{2}$.

The suspended-sediment discharge during the first two major storms in October 1976 and March 1977 after completion and final cleanup of the highway construction was significant. The combined suspended-sediment yield for these two storms was equivalent to 98 percent, 90 percent, and 86 percent of the annual suspended-sediment load for the 1978, 1979 and 1980 water years, respectively. The excessive sediment loads in the intervening drainage associated with these two large storms may not have been the direct result of overland flow.

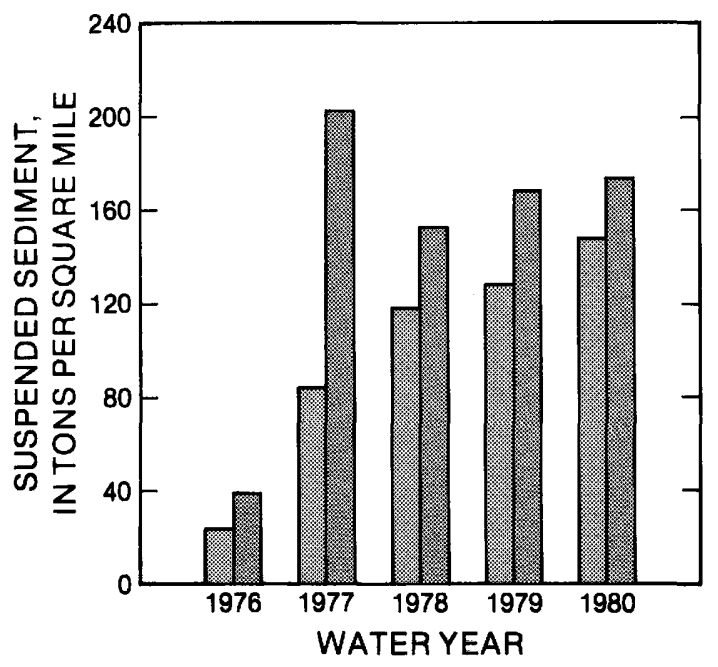

EXPLANATION

Shavers Fork above Bowden (03068600)

Shavers Fork below Bowden (03068800)

Figure 11. Annual suspended-sediment yield at Shavers Fork above and below Bowden, water years 1976-80.
Sediment catchment ponds built in conjunction.with the highway construction could have overflowed, and unstable revegetation could have resulted in high sediment yields. Sediment deposited in the stream bottom and on the sides of the channel by stream rises with lesser velocities could have accumulated and been transported by these two large storms. Noticeable boulder movement was observed by the author at Shavers Fork below Bowden on the recession of the March 13, 1977, storm. Other soil-disturbing activities in addition to the highway construction in this intervening drainage contributed to high sediment yields, but their contribution to the total load was not determined.

Figure 11 is a plot of the annual suspendedsediment yield for the study period in tons per square mile. The yield from the storm of March 13, 1977 , accounted for nearly 15 percent of the 5 -year total suspended-sediment load.

Suspended-sediment regression curves for each water year (1976-80) are shown in figure 12. The slope of any single curve is not significantly different from any other, which indicates no major change in the relationship between suspendedsediment load and streamflow, as would be expected from a major land disturbance. The slight differences in slope were probably the result of changes in annual precipitation.

\section{BASIN COMPARISONS}

The cumulative suspended-sediment discharges (tons $/ \mathrm{mi}^{2}$ ) at the gaging stations at Taylor Run at Bowden and Shavers Fork above and below Bowden for July 1975 to September 1980 are plotted in figure 13. The yield lines for Taylor Run and Shavers Fork above Bowden are generally the same. The major storm of March 13, 1977, after the completion of the highway construction, removed the majority of readily available sediment, which drastically offset the yield line for Shavers Fork below Bowden. The noticeable offset of about 95 tons $/ \mathrm{mi}^{2}$ (fig. 13) is probably the maximum sediment discharge attributable to highway construction.

The sediment yield from spring runoff in the main stem of Shavers Fork seems to be greater than in the Taylor Run basin. Also summer thunderstorms, more local in nature, have a greater impact on sediment yield in the smaller Taylor Run drain- 


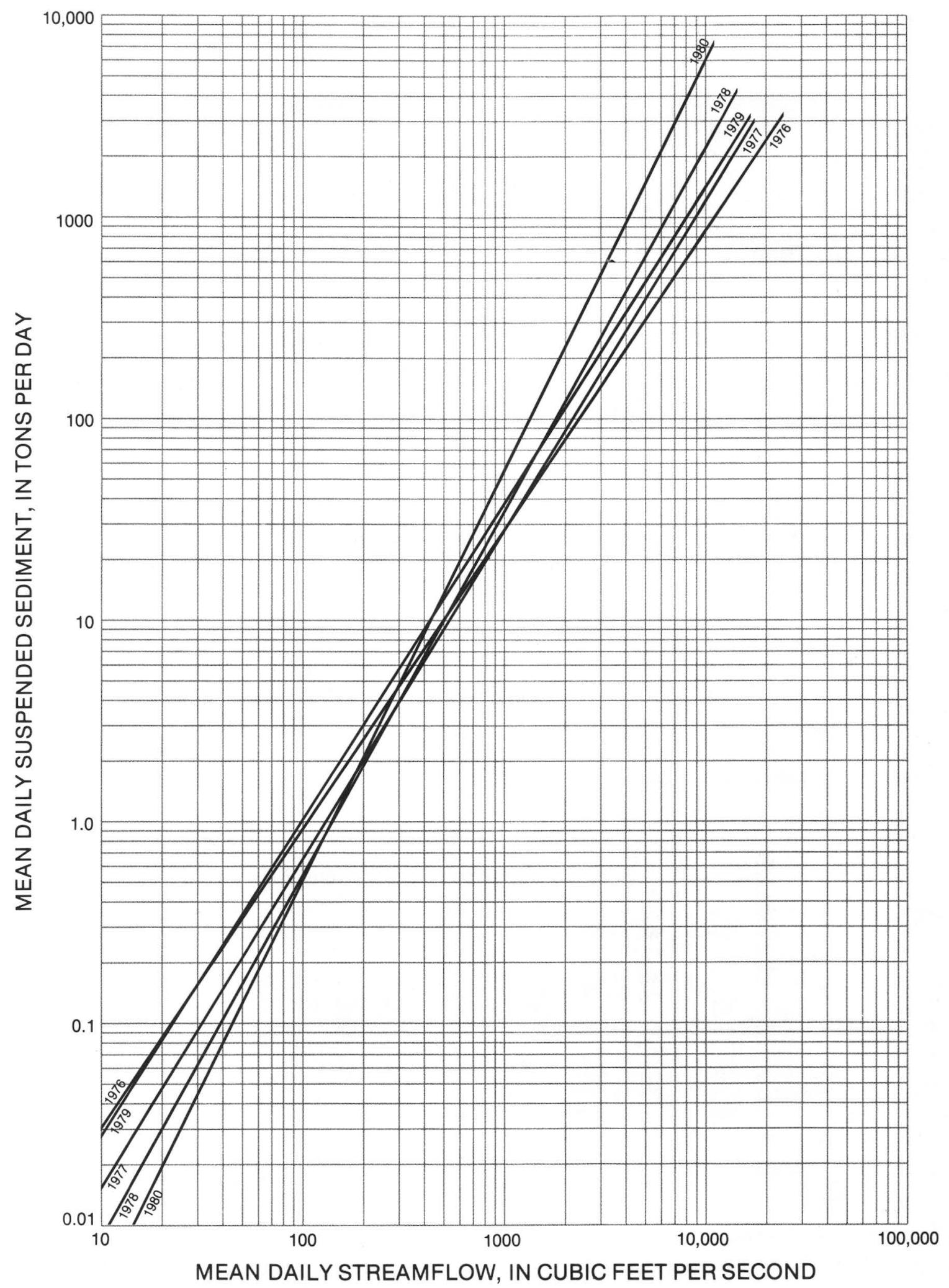

Figure 12. Regression curves of suspended-sediment load versus streamflow at Shavers Fork below Bowden, 1976-80 water years. 


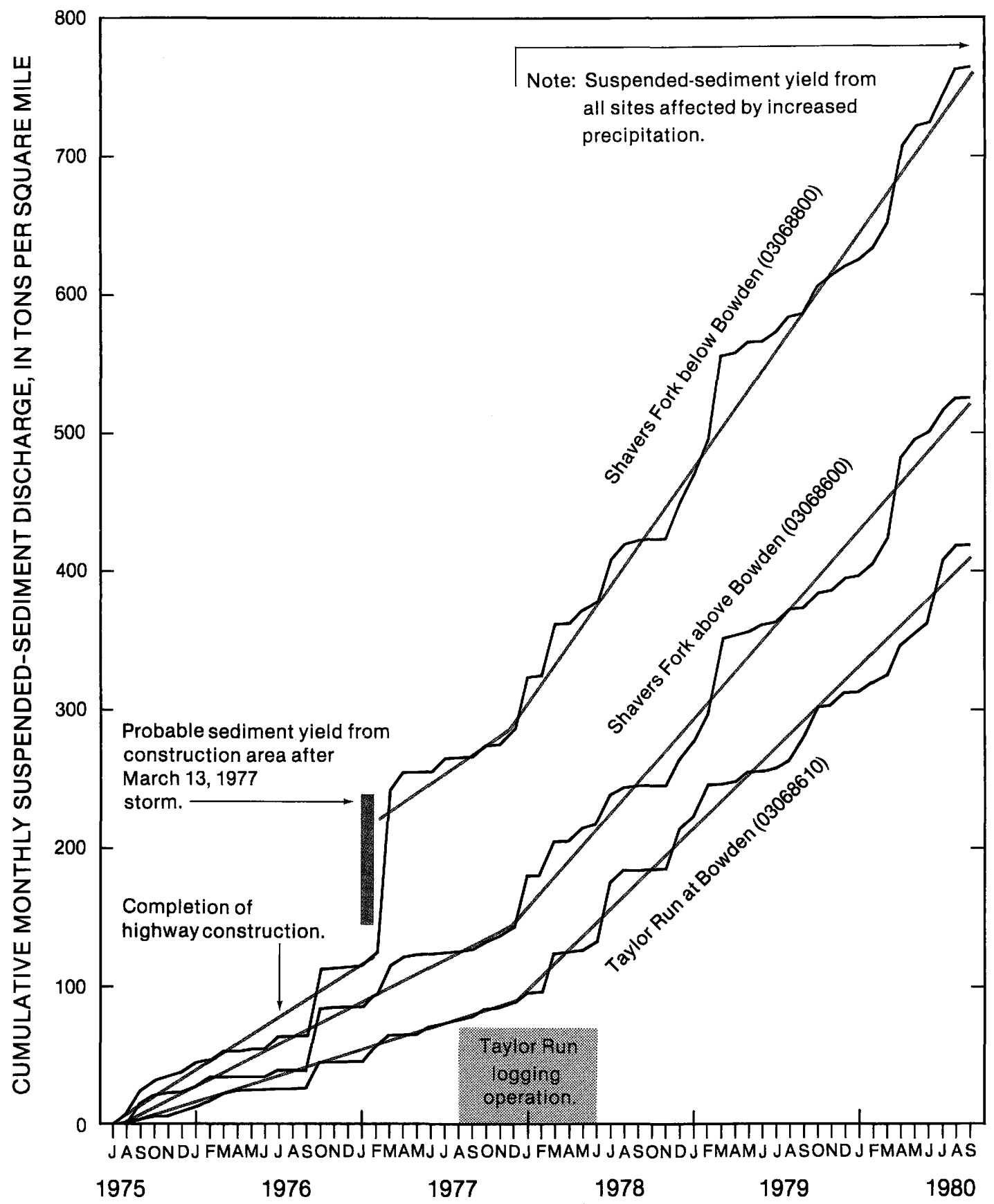

Figure 13. Cumulative suspended-sediment discharge at Taylor Run and Shavers Fork, July 1975 to September 1980 . 
age than in the larger Shavers Fork drainage. Additional activities of man in the Shavers Fork drainage during 1978-80, and increased runoff during this time, account for the upward trend of the suspended-sediment curve for Shavers Fork below Bowden. Little, if any, soil disturbance occurred in the Taylor Run basin after logging ceased in June 1978; the change in slope shown about December 1977 (fig. 13) was probably the result of increased precipitation.

Suspended-sediment yields increase (fig. 13) in the winter owing to the lack of protective foliage and decrease during summer because the soils are sheltered from precipitation by vegetation and by full forest canopies. These effects are often altered, however, by other factors such as topography, soil characteristics, precipitation duration and intensity, land-use practices, percentage of disturbed areas, and the amount of runoff.

Table 7 gives the average annual and 5-year average daily suspended-sediment yield (tons $/ \mathrm{mi}^{2}$ ) for Taylor Run at Bowden and Shavers Fork above and below Bowden. The 5-year average load for Shavers Fork below Bowden was nearly double the load for Taylor Run at Bowden. The graph in figure 14 shows the average daily yield (tons $/ \mathrm{mi}^{2}$ ) at the three daily suspended-sediment stations in the study area.

Table 7. Average daily suspended-sediment yield for gaging stations in the study area.

\begin{tabular}{lccc}
\hline & Average daily suspended-sediment yield, in tons per square mile \\
\cline { 2 - 3 } & $\begin{array}{c}\text { Taylor Run } \\
\text { at Bowden }\end{array}$ & $\begin{array}{c}\text { Shavers Fork } \\
\text { above Bowden }\end{array}$ & $\begin{array}{c}\text { Shavers Fork } \\
\text { below Bowden }\end{array}$ \\
\hline 1976 & 0.06 & 0.06 & 0.11 \\
1977 & .14 & .23 & .56 \\
1978 & .29 & .33 & .42 \\
1979 & .27 & .35 & .48 \\
1980 & .38 & .41 & 0.41 \\
\hline $\begin{array}{l}\text { 5-year } \\
\text { average }\end{array}$ & 0.23 & 0.28 & \\
\hline
\end{tabular}




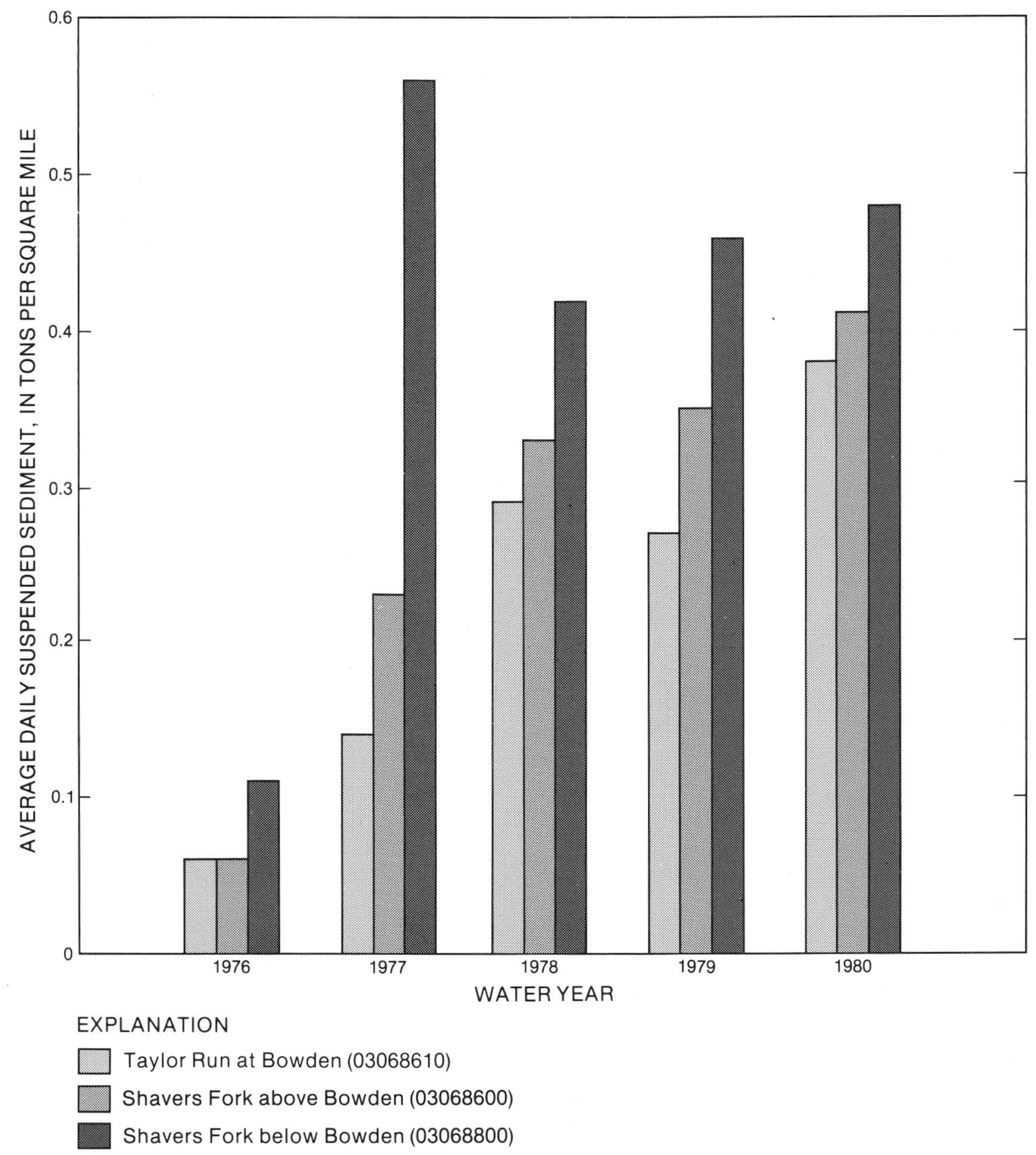

Figure 14. Average daily suspended-sediment yield at Taylor Run and Shavers Fork, water years 1976-80. 


\section{SUMMARY AND CONCLUSIONS}

The first segment of Appalachian Corridor $\mathrm{H}$ highway affecting the Shavers Fork basin disturbed about $0.30 \mathrm{mi}^{2}$ along a 5 -mi zone parallel to Shavers Fork. The highway crosses Shavers Fork, but ends near the mouth of Taylor Run. Construction ended late in the summer of 1976 . Insufficient data were available to determine sediment yields in Shavers Fork before or during highway construction. The U.S. Geological Survey has continued to collect data pending adoption of a final highway location.

Hydrologic data to determine suspended-sediment yields in Shavers Fork and Taylor Run basins were collected from April 1973 to September 1980. The data included daily precipitation, streamflow, and suspended-sediment concentrations.

In Taylor Run basin $\left(5.06 \mathrm{mi}^{2}\right)$, approximately 2,340 tons of suspended sediment was discharge during the 1975-80 water years. Runoff averaged 39.8 in. per year; precipitation averaged 51.5 in. From August 1975 to September 1980, five major storms with rainfall greater than 2.0 in. within 24 hours took place at South Spring, producing runoff that carried nearly 20 percent of the total suspended-sediment load of the 6-year study. The major change in land use in Taylor Run basin during the study was a 70-acre logging operation from 1977 to 1978. Runoff from a major storm 1 month after completion of logging carried nearly 27 percent of the annual suspended-sediment load for the 1978 water year. The rate of sediment discharge changed during the logging operation and continued to increase through 1980 because of increased precipitation. The maximum daily suspended-sediment load during the study was 162 tons on July 3, 1980, which resulted from an intense storm of $3.30 \mathrm{in}$. of precipitation. The 1980 annual precipitation, runoff, and suspended-sediment load was the largest during the 6-year study.
In Shavers Fork basin $\left(151 \mathrm{mi}^{2}\right)$, approximately 111,700 tons of suspended sediment was discharged during the 1976-80 water years. Runoff averaged 37.2 in. per year, 14.3 in. below the average annual precipitation of $51.5 \mathrm{in}$. Numerous changes in land use occurred during the study, including the completion of the first segment of Appalachian Corridor $\mathrm{H}$, which disturbed only 0.2 percent of the drainage basin. Two major storms occurred in the 1977 water year after highway construction was completed in the late summer of 1976. Runoff from these storms carried nearly 75 percent of the annual suspended-sediment load for the 1977 water year. Runoff associated with the storm on March 13, 1977 carried nearly 15 percent of the suspendedsediment load for the study.

\section{Conclusions from this study are:}

1. Suspended-sediment concentrations and therefore suspended-sediment yields are directly affected by the amount of runoff or streamflow within the study area. Precipitation duration and intensity affect sediment yields and can mask natural revegetation and soil stabilization trends.

2. The first intense storm after completion of logging in the Taylor Run basin, and the major storm of March 13, 1977, after completion of highway construction in the Shavers Fork basin, removed most of the readily available sediment from the disturbed area, and resulted in high annual yields.

3. Rate of sediment discharge increased at the end of 1977 in both Taylor Run and Shavers Fork; this is attributed to the increase in precipitation.

4. Average daily suspended-sediment load (tons per square mile) from the Shavers Fork basin was nearly double that from the Taylor Run basin. 


\section{SELECTED REFERENCES}

Baker, Michael, Jr., Inc., 1979, Final report of water-supply investigation, Bowden National Hatchery/Corridor H, Randolph County, West Virginia: Materials report 881097, West Virginia Department of Highways, 1976, unpublished report, p. 11.

Cardwell, D. H., Erwin, R. B., and Woodward, H. P., compilers, 1968, Geologic map of West Virginia: West Virginia Geological and Economic Survey, 1 sheet, scale 1:250,000.

Guy, H. P., 1969, Laboratory theory and methods for sediment analysis: U.S. Geological Survey Techniques of Water-Resources Investigations, Book 5, Chapter C1, $58 \mathrm{p}$.

Porterfield, George, 1972, Computations of fluvial-sediment discharge: U.S. Geological Survey Techniques of Water-Resources Investigations, Book 3, Chapter, C3, $66 \mathrm{p}$.

Reed, Lloyd A., 1978, Effectiveness of sedimentcontrol techniques used during highway construction in central Pennsylvania: U.S. Geological Survey Water-Supply Paper 2054, p. 11.

Reger, David B., 1929, Geologic map II of Pocahontas County: West Virginia Geological Survey, 1 sheet, scale 1:62,500.
1931, Geologic map II of Randolph County: West Virginia Geological Survey, 1 sheet, scale $1: 62,500$.

1931, County reports; Randolph County: West Virginia Geological Survey, p. 76-79.

U.S. Department of Commerce, 1974-1980, Climatological data for West Virginia, Volume 82-88: National Oceanic and Atmospheric Administration, Environmental Data Service.

U.S. Geological Survey, 1973-80, Water resources data for West Virginia: Charleston, U.S. Geological Survey Water-Data Report, Water years 1973-80, (published annually).

West Virginia Department of Highways, 1981, Draft environmental impact statement for Appalachian Corridor $\mathrm{H}$ from Elkins, West Virginia to Interstate 81, Virginia, p. 4-4, 5 .

Yorke, T. H., and Herb, W. J., 1978, Effects of urbanization on streamflow and sediment transport in the Rock Creek and Anacostia River Basins, Montgomery County, Maryland, 1962-74: U.S. Geological Survey Professional Paper 1003, p. 17. 
Table A-1. Water-quality data for 1979 and 1980 water years at Taylor Run near Alpena, West Virginia (station number 03068604, site 3)

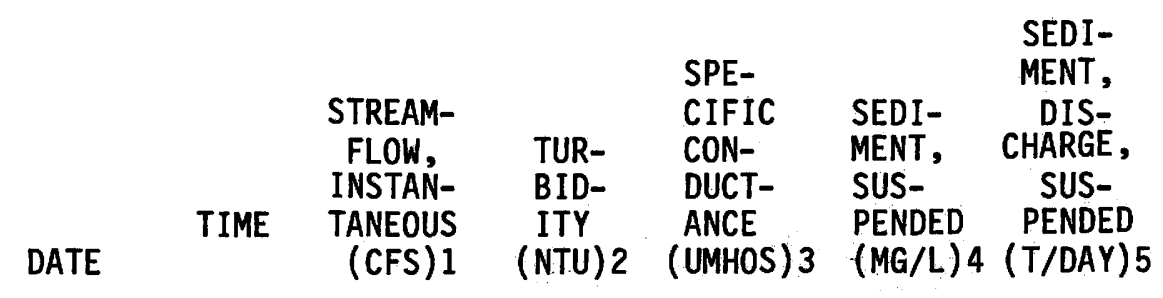

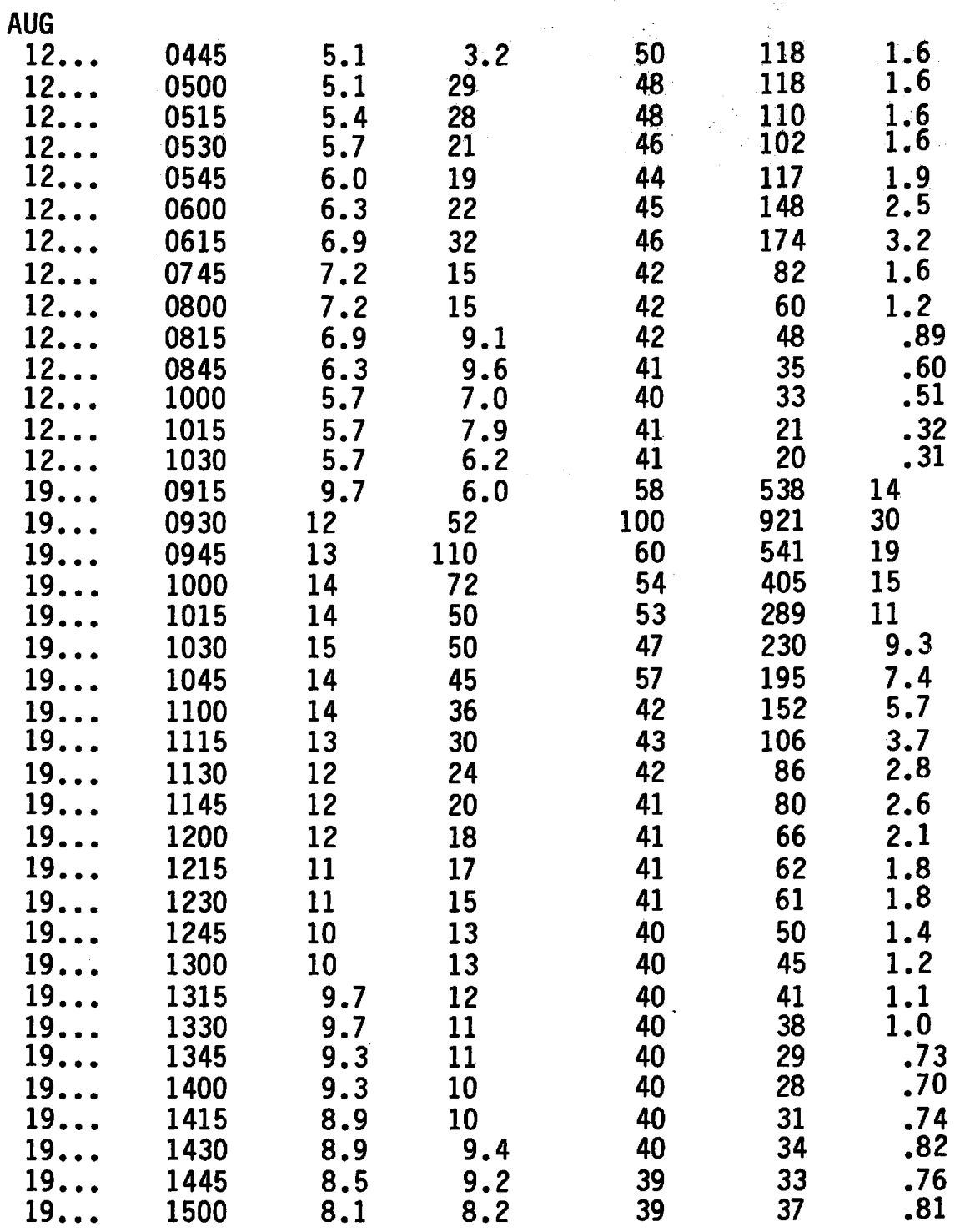




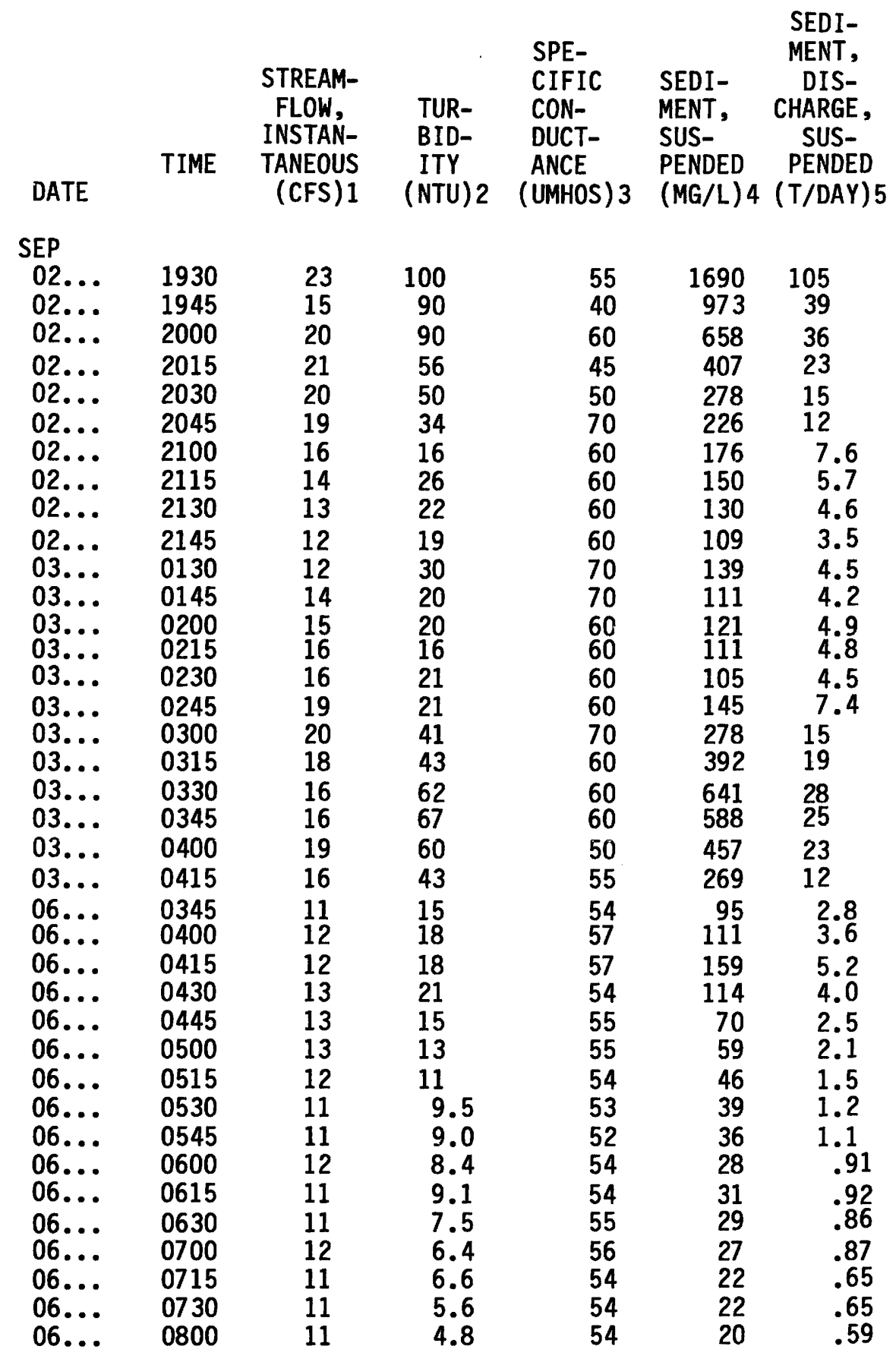

1 Instantaneous streamflow (discharge) expressed in cubic feet per second.

2 Turbidity value expressed as nephelometric turbidity units.

3 Specific conductance expressed in micromhos per centimeter at $25^{\circ} \mathrm{C}$.

4 Instantaneous suspended-sediment concentration expressed in milligrams per liter.

5 Instantaneous suspended-sediment discharge (load) expressed in tons per day. 
Table A-1 Continued. Water-quality data for 1979 and 1980 water years at Taylor Run near Alpena, West Virginia (station number 03068604, site 3)

\begin{tabular}{|c|c|c|c|c|c|c|}
\hline DATE & TIME & $\begin{array}{l}\text { STREAM- } \\
\text { FLOW, } \\
\text { INSTAN- } \\
\text { TANEOUS } \\
\text { (CFS) } 1\end{array}$ & $\begin{array}{l}\text { TUR- } \\
\text { BID- } \\
\text { ITY } \\
\text { (NTU) } 2\end{array}$ & $\begin{array}{l}\text { SPE- } \\
\text { CIFIC } \\
\text { CON- } \\
\text { DUCT- } \\
\text { ANCE } \\
\text { (UMHOS) } 3\end{array}$ & $\begin{array}{l}\text { SEDI- } \\
\text { MENT, } \\
\text { SUS- } \\
\text { PENDED } \\
\text { (MG/L)4 }\end{array}$ & $\begin{array}{l}\text { SEDI- } \\
\text { MENT, } \\
\text { DIS- } \\
\text { CHARGE, } \\
\text { SUS- } \\
\text { PENDED } \\
\text { (T/DAY)5 }\end{array}$ \\
\hline
\end{tabular}

SEP

\begin{tabular}{|c|c|c|c|c|c|c|}
\hline $\begin{array}{l}21 \ldots . \\
21 \ldots \\
21 \ldots \\
21 \ldots \\
21 \ldots \\
21 \ldots \\
21 \ldots \\
21 \ldots \\
21 \ldots \\
21 \ldots \\
21 \ldots \\
21 \ldots \\
21 \ldots \\
21 \ldots \\
21 \ldots \\
21 \ldots \\
21 \ldots \\
21 \ldots \\
21 \ldots \\
21 \ldots \\
21 \ldots \\
21 \ldots \\
21 \ldots \\
0 .\end{array}$ & $\begin{array}{l}1815 \\
1830 \\
1845 \\
1900 \\
1915 \\
1930 \\
1945 \\
2000 \\
2015 \\
2030 \\
2045 \\
2100 \\
2115 \\
2130 \\
2145 \\
2200 \\
2215 \\
2230 \\
2245 \\
2300 \\
2315 \\
2330 \\
2345\end{array}$ & $\begin{array}{l}4.5 \\
4.9 \\
5.7 \\
6.3 \\
6.9 \\
7.2 \\
7.5 \\
7.8 \\
7.8 \\
7.8 \\
7.5 \\
7.2 \\
6.9 \\
6.6 \\
6.3 \\
6.0 \\
6.0 \\
5.7 \\
5.4 \\
5.1 \\
4.9 \\
4.9 \\
4.7\end{array}$ & $\begin{array}{l}14 \\
19 \\
25 \\
34 \\
35 \\
32 \\
30 \\
25 \\
14 \\
12 \\
10 \\
7.5 \\
6.1 \\
5.2 \\
5.5 \\
4.5 \\
4.0 \\
4.0 \\
4.0 \\
3.4 \\
2.9 \\
3.1 \\
2.4\end{array}$ & $\begin{array}{l}70 \\
60 \\
70 \\
70 \\
70 \\
70 \\
60 \\
60 \\
60 \\
60 \\
60 \\
55 \\
60 \\
60 \\
55 \\
55 \\
55 \\
60 \\
60 \\
60 \\
60 \\
60 \\
65\end{array}$ & $\begin{array}{r}56 \\
107 \\
132 \\
179 \\
191 \\
170 \\
147 \\
121 \\
75 \\
53 \\
44 \\
35 \\
28 \\
26 \\
22 \\
20 \\
18 \\
17 \\
16 \\
27 \\
12 \\
12 \\
8\end{array}$ & $\begin{array}{l}.68 \\
1.4 \\
2.0 \\
3.0 \\
3.6 \\
3.3 \\
3.0 \\
2.5 \\
1.6 \\
1.1 \\
.89 \\
.68 \\
.52 \\
.46 \\
.37 \\
.32 \\
.29 \\
.26 \\
.23 \\
.37 \\
.16 \\
.16 \\
.10\end{array}$ \\
\hline $\begin{array}{l}02 \ldots . \\
02 \ldots \\
02 \ldots \\
02 \ldots \\
02 \ldots \\
02 \ldots \\
02 . \ldots \\
02 \ldots \\
02 \ldots \\
02 \ldots \\
02 . . .\end{array}$ & $\begin{array}{l}1845 \\
1900 \\
1915 \\
1930 \\
1945 \\
2000 \\
2015 \\
2030 \\
2045 \\
2100 \\
2115\end{array}$ & $\begin{array}{l}4.9 \\
5.7 \\
5.7 \\
6.0 \\
6.3 \\
6.0 \\
6.0 \\
6.0 \\
6.0 \\
5.4 \\
5.1\end{array}$ & $\begin{array}{l}50 \\
90 \\
55 \\
30 \\
23 \\
18 \\
16 \\
14 \\
12 \\
10 \\
10\end{array}$ & $\begin{array}{r}74 \\
156 \\
107 \\
81 \\
79 \\
78 \\
74 \\
75 \\
73 \\
72 \\
70\end{array}$ & $\begin{array}{r}250 \\
282 \\
191 \\
118 \\
84 \\
58 \\
46 \\
38 \\
35 \\
26 \\
25\end{array}$ & $\begin{array}{l}3.3 \\
4.3 \\
2.9 \\
1.9 \\
1.4 \\
.94 \\
.75 \\
.62 \\
.57 \\
.38 \\
34\end{array}$ \\
\hline $\begin{array}{c}02 \ldots \\
02 \ldots \\
02 \ldots \\
02 . . . \\
\text { NOV }\end{array}$ & $\begin{array}{l}2130 \\
2145 \\
2200 \\
2215\end{array}$ & $\begin{array}{l}5.1 \\
4.7 \\
4.5 \\
4.5\end{array}$ & $\begin{array}{r}8.1 \\
7.4 \\
5.8 \\
5.5\end{array}$ & $\begin{array}{l}69 \\
70 \\
68 \\
68\end{array}$ & $\begin{array}{l}20 \\
19 \\
19 \\
16 \\
11\end{array}$ & $\begin{array}{l}.34 \\
.26 \\
.24 \\
.19 \\
.13\end{array}$ \\
\hline $\begin{array}{l}02 \ldots \\
02 \ldots \\
02 \ldots \\
02 \ldots \\
02 . . .\end{array}$ & $\begin{array}{l}1230 \\
1245 \\
1300 \\
1315 \\
1330\end{array}$ & $\begin{array}{l}12 \\
12 \\
12 \\
12 \\
12\end{array}$ & $\begin{array}{l}7.6 \\
3.5 \\
8.6 \\
5.5 \\
4.5\end{array}$ & $\begin{array}{l}42 \\
41 \\
41 \\
41 \\
41\end{array}$ & $\begin{array}{l}45 \\
37 \\
31 \\
23 \\
22\end{array}$ & $\begin{array}{l}1.5 \\
1.2 \\
1.0 \\
.75 \\
.71\end{array}$ \\
\hline
\end{tabular}




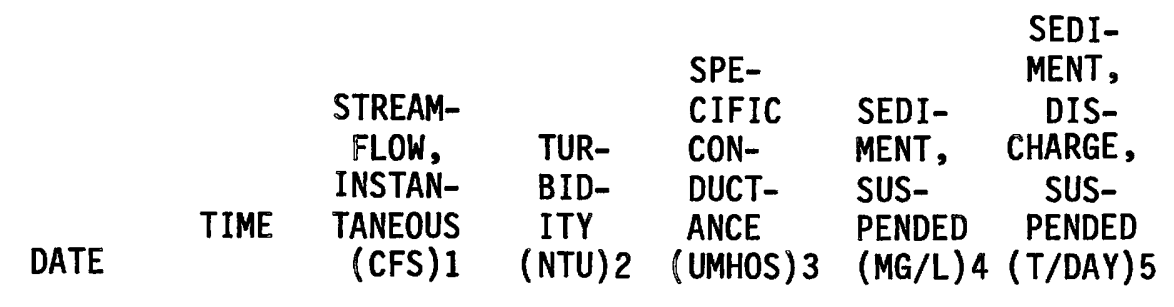

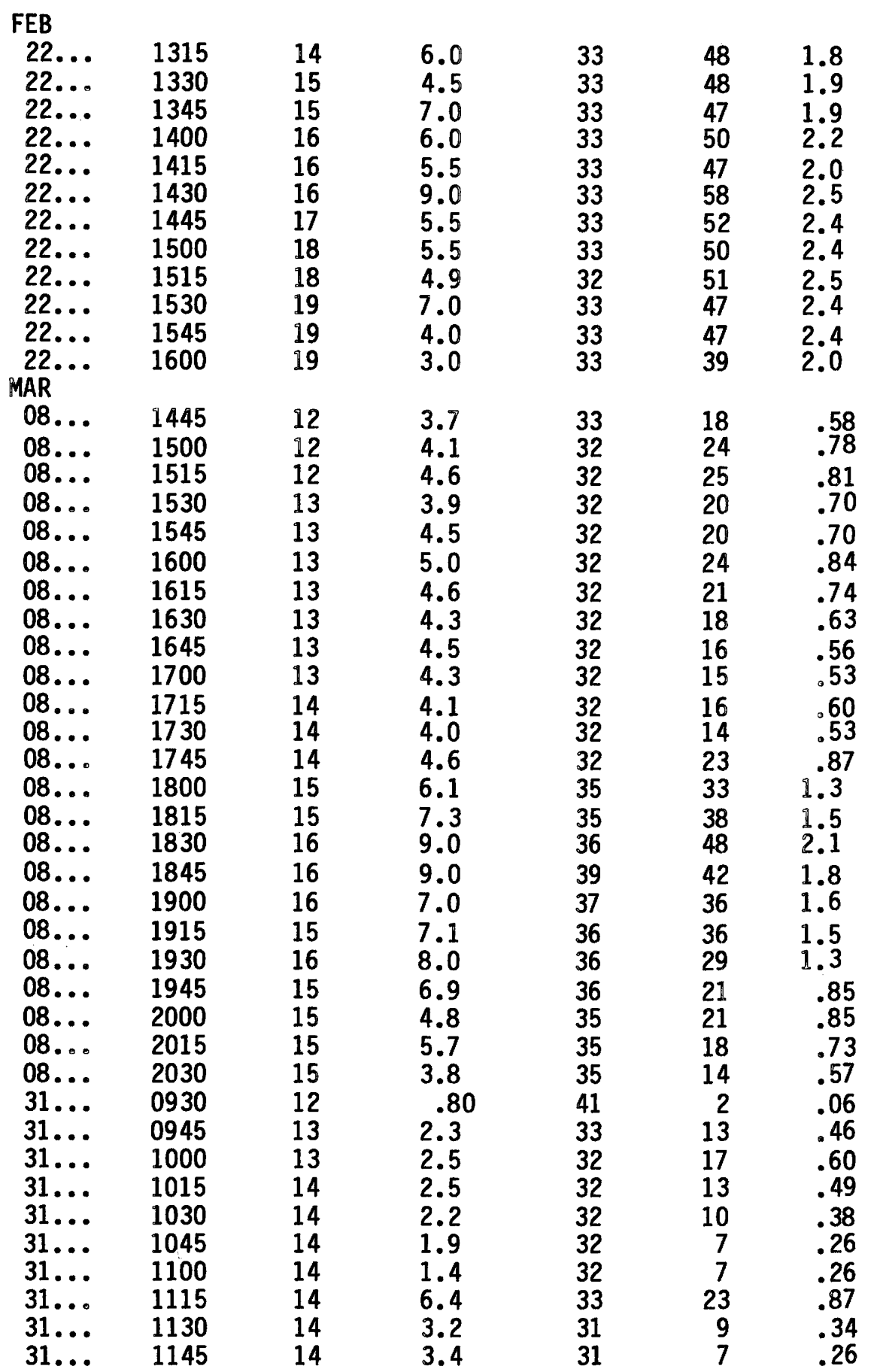

1 Instantaneous streamflow (discharge) expressed in cubic feet per second

2 Turbidity value expressed as nephelometric turbidity units.

3 Specific conductance expressed in micromhos per centimeter at $25^{\circ} \mathrm{C}$.

4 Instantaneous suspended-sediment concentration expressed in milligrams per liter.

5 Instantaneous suspended-sediment discharge (10ad) expressed in tons per day. 
Table A-1 Continued. Water-quality data for 1979 and 1980 water years at Taylor Run near Alpena, West Virginia (station number 03068604, site 3)

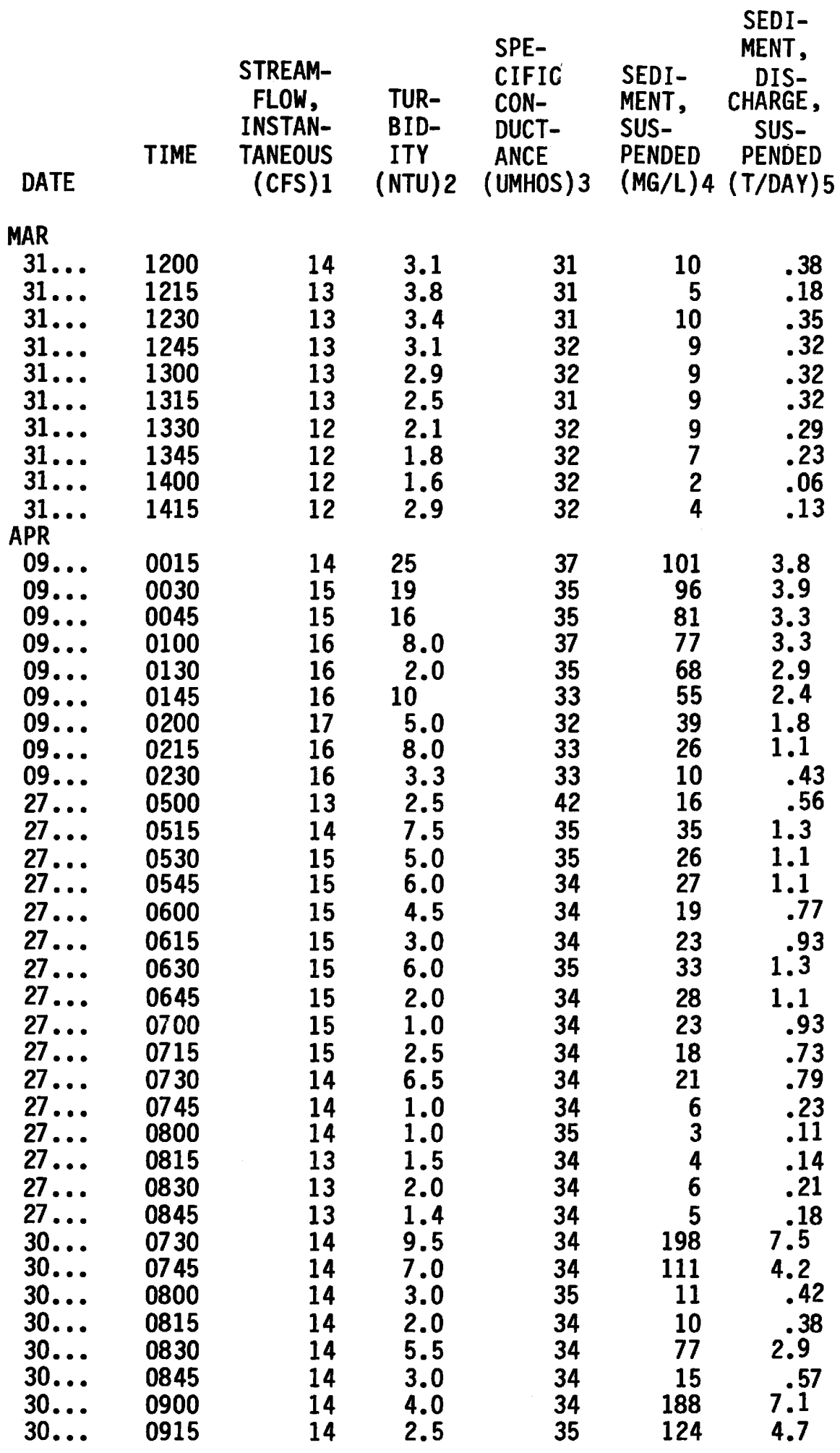




\begin{tabular}{|c|c|c|c|c|c|c|}
\hline ATE & TIME & $\begin{array}{l}\text { STREAM- } \\
\text { FLOW, } \\
\text { INSTAN- } \\
\text { TANEOUS } \\
\text { (CFS) } 1\end{array}$ & $\begin{array}{l}\text { TUR- } \\
\text { BID- } \\
\text { ITY } \\
\text { (NTU)2 }\end{array}$ & $\begin{array}{l}\text { SPE- } \\
\text { CIFIC } \\
\text { CON- } \\
\text { DUCT- } \\
\text { ANCE } \\
(\text { UMHOS) } 3\end{array}$ & $\begin{array}{l}\text { SEDI- } \\
\text { MENT, } \\
\text { SUS- } \\
\text { PENDED } \\
(M G / L) 4\end{array}$ & $\begin{array}{l}\text { SEDI- } \\
\text { MENT, } \\
\text { DIS- } \\
\text { CHARGE, } \\
\text { SUS- } \\
\text { PENDED } \\
(T / D A Y) 5\end{array}$ \\
\hline
\end{tabular}

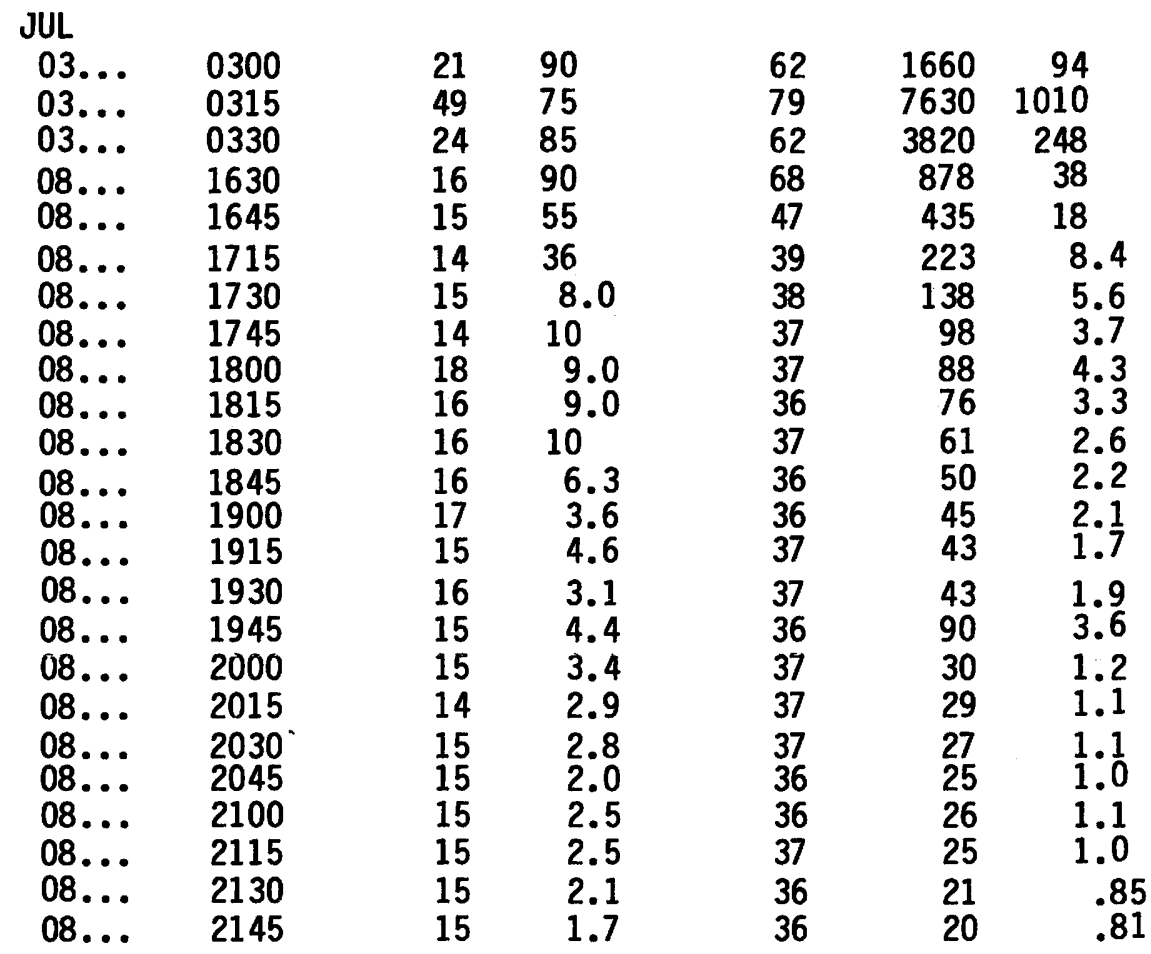

1 Instantaneous streamflow (discharge) expressed in cubic feet per second.

2 Turbidity value expressed as nephelometric turbidity units.

3 Specific conductance expressed in micromhos per centimeter at $25^{\circ} \mathrm{C}$.

4 Instantaneous suspended-sediment concentration expressed in milligrams per liter.

5 Instantaneous suspended-sediment discharge (load) expressed in tons per day. 
Table A-2. Water-quality data for 1979 and 1980 water years at Stalnaker Run near Bowden, West Virginia (station number 03068607, site 4)

\begin{tabular}{|c|c|c|c|c|c|c|}
\hline DATE & TIME & $\begin{array}{l}\text { STREAM- } \\
\text { FLOW, } \\
\text { INSTAN- } \\
\text { TANEOUS } \\
\text { (CFS) } 1\end{array}$ & $\begin{array}{l}\text { TUR- } \\
\text { BID- } \\
\text { ITY } \\
\text { (NTU) } 2\end{array}$ & $\begin{array}{l}\text { SPE- } \\
\text { CIFIC } \\
\text { CON- } \\
\text { DUCT- } \\
\text { ANCE } \\
\text { (UMHOS) } 3\end{array}$ & $\begin{array}{l}\text { SEDI- } \\
\text { MENT, } \\
\text { SUS- } \\
\text { PENDED } \\
(M G / L) 4\end{array}$ & $\begin{array}{c}\text { SEDI- } \\
\text { MENT, } \\
\text { DIS- } \\
\text { CHARGE, } \\
\text { SUS-- } \\
\text { PENDED } \\
(\text { T/DAY } 5\end{array}$ \\
\hline $\begin{array}{c}\text { APR } \\
26 \ldots \\
26 \ldots \\
26 \ldots \\
26 \ldots \\
26 \ldots \\
26 \ldots \\
26 \ldots \\
26 \ldots \\
27 \ldots \\
27 \ldots \\
27 \ldots \\
27 \ldots \\
27 \ldots \\
27 \ldots \\
27 \ldots \\
27 \ldots \\
27 \ldots \\
27 \ldots \\
27 \ldots \\
27 \ldots \\
27 \ldots \\
27 \ldots \\
27 \ldots \\
27 \ldots\end{array}$ & $\begin{array}{l}2215 \\
2230 \\
2245 \\
2300 \\
2315 \\
2330 \\
2345 \\
2400 \\
0015 \\
0030 \\
0045 \\
0100 \\
0115 \\
0130 \\
0145 \\
0200 \\
0215 \\
0230 \\
0245 \\
0300 \\
0315 \\
0330 \\
0345 \\
0400\end{array}$ & $\begin{array}{l}8.3 \\
9.7 \\
11 \\
12 \\
13 \\
13 \\
13 \\
13 \\
12 \\
12 \\
12 \\
12 \\
12 \\
12 \\
11 \\
11 \\
11 \\
11 \\
10 \\
10 \\
10 \\
10 \\
10\end{array}$ & $\begin{array}{c}40 \\
45 \\
45 \\
33 \\
20 \\
21 \\
17 \\
14 \\
13 \\
8.9 \\
11 \\
10 \\
8.6 \\
8.0 \\
7.5 \\
6.6 \\
7.0 \\
6.0 \\
5.3 \\
5.0 \\
4.4 \\
5.7 \\
6.8 \\
6.3\end{array}$ & $\begin{array}{l}25 \\
25 \\
24 \\
24 \\
24 \\
24 \\
24 \\
24 \\
25 \\
25 \\
25 \\
25 \\
25 \\
25 \\
25 \\
25 \\
25 \\
25 \\
25 \\
25 \\
25 \\
25 \\
25 \\
25\end{array}$ & $\begin{array}{r}186 \\
209 \\
174 \\
142 \\
103 \\
89 \\
66 \\
54 \\
44 \\
35 \\
35 \\
29 \\
27 \\
26 \\
21 \\
22 \\
19 \\
17 \\
15 \\
16 \\
14 \\
17 \\
17 \\
18\end{array}$ & $\begin{array}{l}4.2 \\
5.5 \\
5.2 \\
4.6 \\
3.6 \\
3.1 \\
2.3 \\
1.9 \\
1.4 \\
1.1 \\
1.1 \\
.94 \\
.87 \\
.84 \\
.62 \\
.65 \\
.56 \\
.50 \\
.41 \\
.43 \\
.38 \\
.46 \\
.46 \\
.49\end{array}$ \\
\hline
\end{tabular}




\begin{tabular}{|c|c|c|c|c|c|c|}
\hline DATE & TIME & $\begin{array}{l}\text { STREAM- } \\
\text { FLOW, } \\
\text { INSTAN- } \\
\text { TANEOUS } \\
\text { (CFS) } 1\end{array}$ & $\begin{array}{l}\text { TUR- } \\
\text { BID- } \\
\text { ITY } \\
\text { (NTU) } 2\end{array}$ & $\begin{array}{l}\text { SPE- } \\
\text { CIFIC } \\
\text { CON- } \\
\text { DUCT- } \\
\text { ANCE } \\
\text { (UMHOS) } 3\end{array}$ & $\begin{array}{l}\text { SEDI- } \\
\text { MENT, } \\
\text { SUS- } \\
\text { PENDED } \\
\text { (MG/L)4 }\end{array}$ & $\begin{array}{c}\text { SEDI- } \\
\text { MENT, } \\
\text { DIS- } \\
\text { CHARGE, } \\
\text { SUS- } \\
\text { PENDED } \\
(\text { T/DAY } 5\end{array}$ \\
\hline $\begin{array}{c}\text { MAY } \\
10 \ldots \\
10 \ldots \\
10 \ldots \\
10 \ldots \\
10 \ldots \\
10 \ldots \\
10 \ldots \\
10 \ldots \\
10 \ldots \\
10 \ldots \\
10 \ldots \\
10 \ldots \\
10 \ldots \\
10 \ldots \\
10 \ldots \\
10 \ldots \\
10 \ldots \\
10 \ldots \\
10 \ldots \\
10 \ldots \\
10 \ldots \\
10 \ldots \\
13 \ldots \\
13 \ldots \\
13 \ldots \\
13 \ldots \\
13 \ldots \\
13 \ldots \\
13 \ldots \\
13 \ldots \\
13 \ldots \\
13 \ldots \\
13 \ldots \\
13 \ldots \\
13 \ldots \\
13 \ldots \\
13 \ldots\end{array}$ & $\begin{array}{l}1445 \\
1515 \\
1530 \\
1545 \\
1600 \\
1615 \\
1630 \\
1645 \\
1700 \\
1715 \\
1730 \\
1745 \\
1800 \\
1815 \\
1830 \\
1845 \\
1900 \\
1915 \\
1930 \\
1945 \\
2000 \\
2015 \\
1000 \\
1100 \\
1200 \\
1300 \\
1400 \\
1500 \\
1600 \\
1700 \\
1800 \\
1900 \\
2000 \\
2100 \\
2200 \\
2300 \\
2400\end{array}$ & $\begin{array}{l}18 \\
22 \\
21 \\
20 \\
20 \\
20 \\
19 \\
18 \\
17 \\
16 \\
15 \\
15 \\
14 \\
14 \\
13 \\
13 \\
12 \\
12 \\
12 \\
12 \\
11 \\
11 \\
15 \\
15 \\
15 \\
15 \\
14 \\
14 \\
14 \\
13 \\
13 \\
13 \\
12 \\
12 \\
12 \\
12 \\
12\end{array}$ & $\begin{array}{r}110 \\
100 \\
55 \\
85 \\
45 \\
35 \\
27 \\
17 \\
23 \\
16 \\
16 \\
13 \\
14 \\
15 \\
10 \\
10 \\
8.4 \\
6.4 \\
9.2 \\
8.9 \\
8.1 \\
9.4 \\
6.4 \\
7.5 \\
6.1 \\
5.6 \\
5.0 \\
5.8 \\
4.8 \\
4.0 \\
4.4 \\
3.1 \\
4.7 \\
4.8 \\
4.4 \\
3.9 \\
4.0\end{array}$ & $\begin{array}{l}27 \\
25 \\
25 \\
25 \\
25 \\
25 \\
26 \\
25 \\
25 \\
25 \\
25 \\
25 \\
25 \\
25 \\
25 \\
25 \\
25 \\
25 \\
25 \\
25 \\
25 \\
25 \\
27 \\
24 \\
24 \\
23 \\
24 \\
23 \\
23 \\
23 \\
23 \\
23 \\
23 \\
23 \\
23 \\
24 \\
24\end{array}$ & $\begin{array}{r}1620 \\
615 \\
249 \\
351 \\
205 \\
136 \\
69 \\
99 \\
82 \\
69 \\
66 \\
50 \\
48 \\
45 \\
37 \\
37 \\
34 \\
28 \\
28 \\
26 \\
27 \\
24 \\
31 \\
40 \\
25 \\
23 \\
18 \\
21 \\
19 \\
17 \\
18 \\
18 \\
18 \\
22 \\
22 \\
20 \\
19\end{array}$ & $\begin{array}{l}79 \\
37 \\
14 \\
19 \\
11 \\
7.3 \\
3.5 \\
4.8 \\
3.8 \\
3.0 \\
2.7 \\
2.0 \\
1.8 \\
1.7 \\
1.3 \\
1.3 \\
1.1 \\
.91 \\
.91 \\
.84 \\
.80 \\
.71 \\
1.3 \\
1.6 \\
1.0 \\
.93 \\
.68 \\
.79 \\
.72 \\
.60 \\
.63 \\
.63 \\
.58 \\
.71 \\
.71 \\
.65 \\
.62\end{array}$ \\
\hline
\end{tabular}

1 Instantaneous streamflow (discharge) expressed in cubic feet per second.

2 Turbidity value expressed as nephelometric turbidity units.

3 Specific conductance expressed in micromhos per centimeter at $25^{\circ} \mathrm{C}$.

4 Instantaneous suspended-sediment concentration expressed in milligrams per liter.

5 Instantaneous suspended-sediment discharge (load) expressed in tons per day. 
Table A-2 Continued. Water-quality data for 1979 and 1980 water years at Stalnaker Run near Bowden, West Virginia (station number 03068607, site 4)

\begin{tabular}{|c|c|c|c|c|c|c|}
\hline DATE & TIME & $\begin{array}{l}\text { STREAM- } \\
\text { FLOW, } \\
\text { INSTAN- } \\
\text { TANEOUS } \\
\text { (CFS) } 1\end{array}$ & $\begin{array}{l}\text { TUR- } \\
\text { BID- } \\
\text { ITY } \\
\text { (NTU)2 }\end{array}$ & $\begin{array}{l}\text { SPE- } \\
\text { CIFIC } \\
\text { CON- } \\
\text { DUCT- } \\
\text { ANCE } \\
\text { (UMHOS) } 3\end{array}$ & $\begin{array}{l}\text { SEDI- } \\
\text { MENT, } \\
\text { SUS- } \\
\text { PENDED } \\
(M G / L) 4\end{array}$ & $\begin{array}{c}\text { SEDI- } \\
\text { MENT, } \\
\text { DIS- } \\
\text { CHARGE, } \\
\text { SUS- } \\
\text { PENDED } \\
\text { (T/DAY) } 5\end{array}$ \\
\hline \multicolumn{7}{|l|}{ MAY } \\
\hline $14 .$. & 0100 & 12 & 5.4 & 23 & 20 & .65 \\
\hline $14 \ldots$ & 0200 & 12 & 3.8 & 23 & 17 & .55 \\
\hline $14 .$. & 0300 & 11 & 3.9 & 23 & 16 & .48 \\
\hline 14. & 0400 & 11 & 3.6 & 23 & 16 & .48 \\
\hline 14. & 0500 & 11 & 2.5 & 23 & 14 & .42 \\
\hline 14. & 0600 & 11 & 3.0 & 22 & 16 & .48 \\
\hline 14. & 0700 & 11 & 3.9 & 24 & 16 & .48 \\
\hline 14. & 0800 & 11 & 4.7 & 22 & 15 & .45 \\
\hline 14. & 0900 & 11 & 4.8 & 22 & 18 & .53 \\
\hline & $\begin{array}{l}0430 \\
0445\end{array}$ & & & $\begin{array}{l}28 \\
23\end{array}$ & $\begin{array}{l}186 \\
185\end{array}$ & $\begin{array}{l}4.4 \\
5.0\end{array}$ \\
\hline 24. & 0500 & 11 & 40 & 23 & 168 & 5.0 \\
\hline 24. & 0515 & 12 & $\begin{array}{l}36 \\
30\end{array}$ & $\begin{array}{l}23 \\
23\end{array}$ & $\begin{array}{l}153 \\
122\end{array}$ & $\begin{array}{l}5.0 \\
4.0\end{array}$ \\
\hline $\begin{array}{l}24 . \\
24 .\end{array}$ & $\begin{array}{l}0530 \\
0545\end{array}$ & $\begin{array}{l}12 \\
12\end{array}$ & $\begin{array}{l}30 \\
24\end{array}$ & $\begin{array}{l}23 \\
23\end{array}$ & $\begin{array}{r}122 \\
99\end{array}$ & $\begin{array}{l}4.0 \\
3.2\end{array}$ \\
\hline 24. & 0600 & 12 & 20 & 23 & 82 & 2.7 \\
\hline 24. & 0615 & 12 & 17 & 23 & $\begin{array}{l}70 \\
62\end{array}$ & 2.3 \\
\hline $\begin{array}{l}24 . \\
24\end{array}$ & $\begin{array}{l}0630 \\
0645\end{array}$ & $\begin{array}{l}12 \\
12\end{array}$ & $\begin{array}{l}14 \\
13\end{array}$ & $\begin{array}{l}23 \\
23\end{array}$ & $\begin{array}{l}63 \\
53\end{array}$ & $\begin{array}{l}2.0 \\
1.7\end{array}$ \\
\hline $\begin{array}{l}24 . \\
24 .\end{array}$ & $\begin{array}{l}0645 \\
0700\end{array}$ & $\begin{array}{l}12 \\
12\end{array}$ & $\begin{array}{l}13 \\
12\end{array}$ & $\begin{array}{l}23 \\
23\end{array}$ & $\begin{array}{l}53 \\
42\end{array}$ & $\begin{array}{l}1.7 \\
1.4\end{array}$ \\
\hline & 0715 & 12 & 10 & 23 & 39 & 1.3 \\
\hline 24. & 0730 & 12 & 8.8 & 23 & 34 & 1.1 \\
\hline & 0745 & 12 & 8.4 & 23 & 31 & $\begin{array}{l}1.0 \\
.97\end{array}$ \\
\hline $\begin{array}{l}24 . \\
24 .\end{array}$ & $\begin{array}{l}0800 \\
0815\end{array}$ & $\begin{array}{l}12 \\
12\end{array}$ & $\begin{array}{l}6.5 \\
6.9\end{array}$ & $\begin{array}{l}23 \\
23\end{array}$ & $\begin{array}{l}30 \\
27\end{array}$ & $\begin{array}{l}.97 \\
.87\end{array}$ \\
\hline 24. & 0830 & 11 & 7.4 & 24 & 26 & .77 \\
\hline & 0845 & 11 & 6.2 & 24 & 22 & .65 \\
\hline & & 11 & 6.0 & 24 & 20 & .59 \\
\hline & 0915 & 11 & 6.6 & 24 & 21 & .62 \\
\hline & 0900 & 17 & 5.4 & 32 & 33 & 1.5 \\
\hline & 0930 & 17 & 5.5 & 31 & 20 & .92 \\
\hline & 1100 & 16 & 5.6 & 27 & 31 & 1.3 \\
\hline & & 15 & 7.2 & 26 & 17 & $\begin{array}{r}.69 \\
68\end{array}$ \\
\hline & & & & & & \\
\hline & 1700 & 13 & 4.4 & 25 & 10 & $\begin{array}{r}35 \\
.42\end{array}$ \\
\hline & $\begin{array}{l}1900 \\
2100\end{array}$ & $\begin{array}{l}12 \\
12\end{array}$ & 4. & $\begin{array}{l}25 \\
25\end{array}$ & $\begin{array}{l}13 \\
13\end{array}$ & .42 \\
\hline & 2300 & 12 & & 25 & 10 & 32 \\
\hline
\end{tabular}




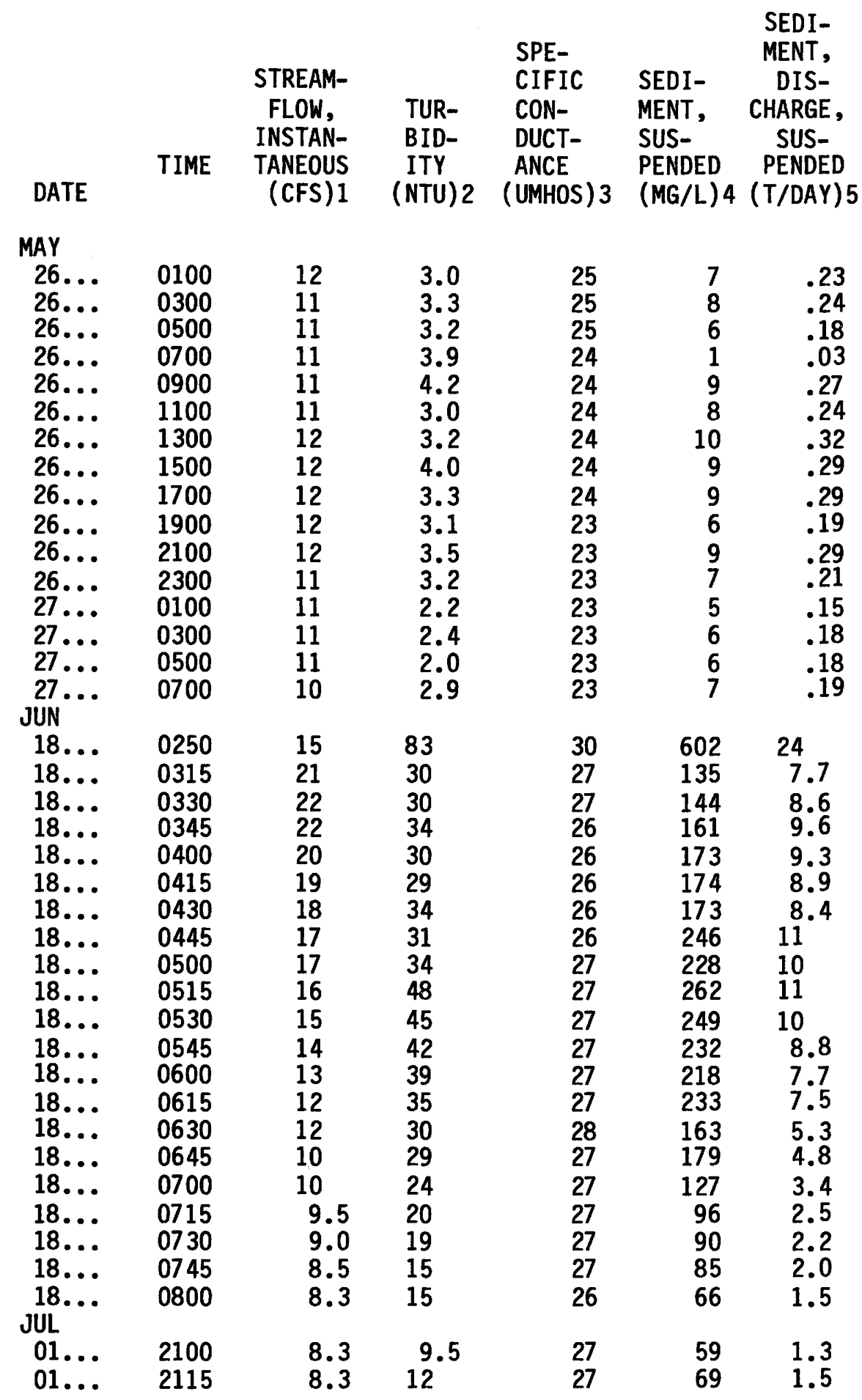

1 Instantaneous streamflow (discharge) expressed in cubic feet per second.

2 Turbidity value expressed as nephelometric turbidity units.

3 Specific conductance expressed in micromhos per centimeter at $25^{\circ} \mathrm{C}$.

4 Instantaneous suspended-sediment concentration expressed in milligrams per liter.

5 Instantaneous suspended-sediment discharge (10ad) expressed in tons per day. 
Table A-2 Continued. Water-quality data for 1979 and 1980 water years at Stalnaker Run near Bowden, West Virginia (station number 03068607, site 4)

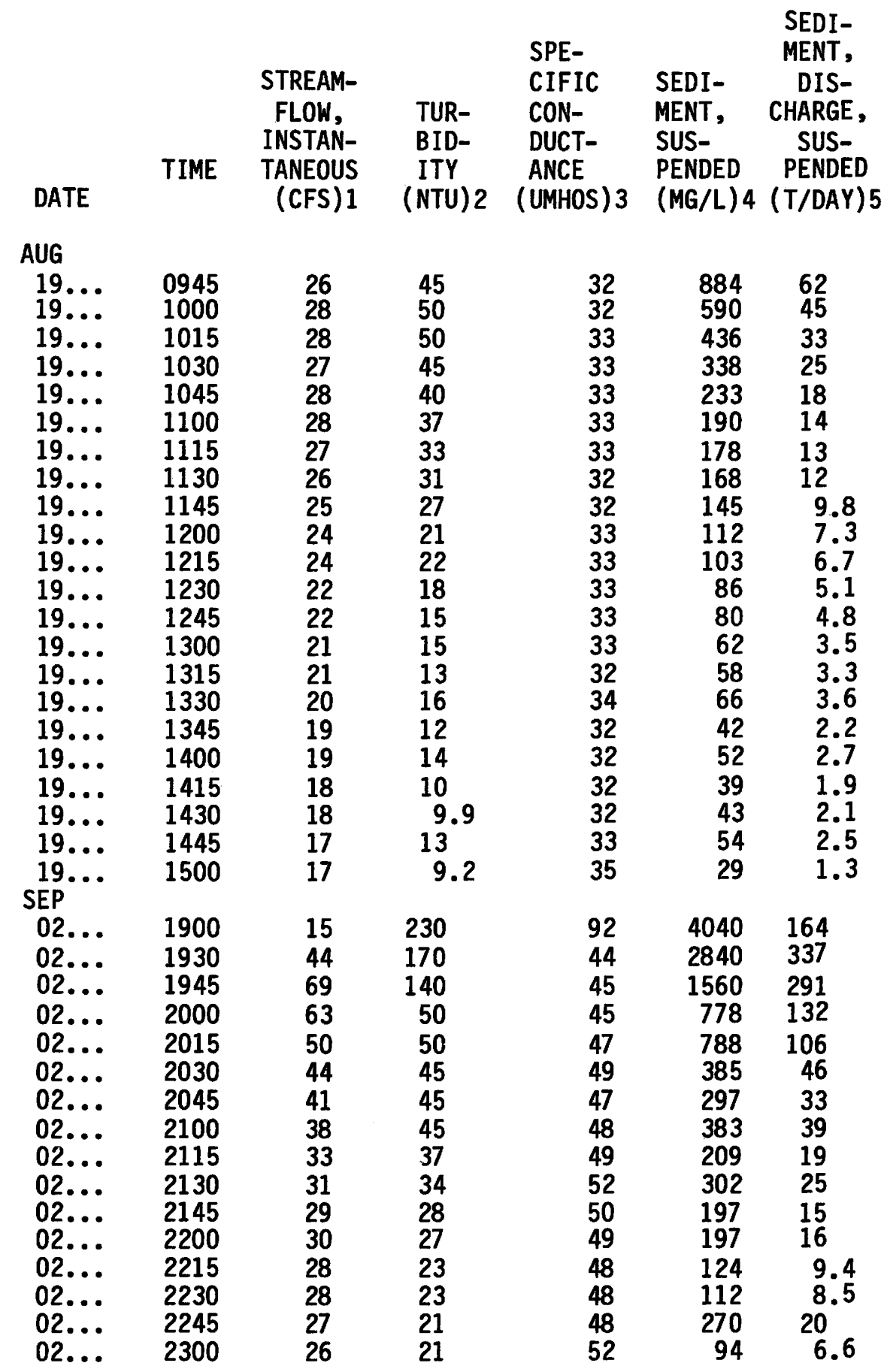




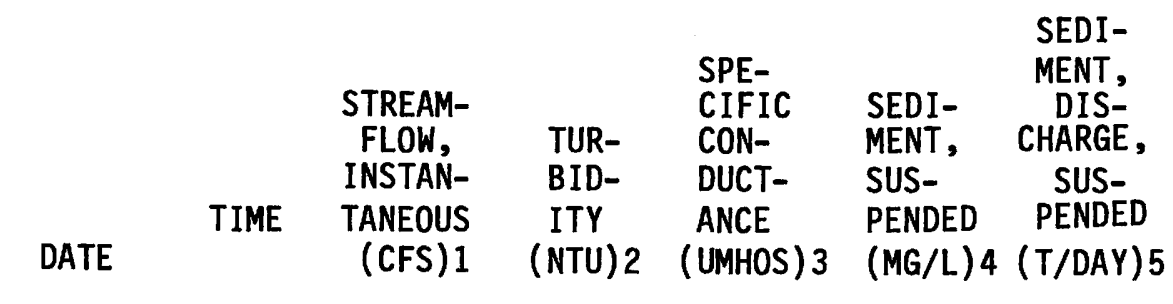

\begin{tabular}{|c|c|c|c|c|c|c|}
\hline \multicolumn{7}{|l|}{ FEB } \\
\hline \multicolumn{7}{|c|}{$\begin{array}{l}1115 \\
1130\end{array}$} \\
\hline $22 \ldots$ & 1145 & 30 & 9.0 & 40 & 77 & 6.2 \\
\hline 22... & 1200 & 31 & 11 & 40 & 87 & 7.3 \\
\hline $22 \ldots$ & 1215 & 32 & 9.0 & 39 & 89 & 7.7 \\
\hline $22 \ldots$ & 1230 & 33 & 10 & 39 & 120 & 11 \\
\hline 22... & 1245 & 34 & 14 & 40 & 126 & 12 \\
\hline 22... & 1300 & 35 & 13 & 39 & 139 & 13 \\
\hline $22 \ldots$ & 1315 & 36 & 17 & 41 & 146 & 14 \\
\hline $22 \ldots$ & 1330 & 36 & 18 & 40 & 145 & 14 \\
\hline 22. & 1345 & 36 & 17 & 42 & 145 & 14 \\
\hline 22. & 1400 & 37 & 13 & 41 & 140 & 14 \\
\hline 22... & 1415 & 38 & 12 & 39 & 122 & 13 \\
\hline MAR $22 \ldots$ & 1430 & 38 & 19 & 37 & 110 & 11 \\
\hline $08 \ldots$ & 1000 & 16 & 2.3 & 31 & 7 & .30 \\
\hline 08.. & 1100 & 16 & 1.5 & 31 & 5 & .22 \\
\hline 08. & 1200 & 16 & 2.8 & 33 & 9 & .39 \\
\hline $08 \ldots$ & 1300 & 16 & 2.5 & 31 & 9 & .39 \\
\hline $08 \ldots$ & 1400 & 17 & 2.4 & 31 & 9 & .41 \\
\hline $08 \ldots$ & 1500 & 18 & 3.1 & 31 & 10 & .49 \\
\hline $08 \ldots$ & 1600 & 18 & 3.7 & 33 & 15 & .73 \\
\hline $08 \ldots$ & 1700 & 19 & 4.4 & 31 & 13 & .67 \\
\hline 08. & 1800 & 20 & 3.5 & 32 & 27 & 1.5 \\
\hline 08 . & 1900 & 21 & 2.9 & 33 & 12 & .68 \\
\hline $08 \ldots$ & 2000 & 20 & 3.4 & 33 & 9 & .49 \\
\hline $08 \ldots$ & 2100 & 20 & 2.4 & 34 & 9 & .49 \\
\hline $08 \ldots$ & 2200 & 19 & 2.5 & 32 & 7 & .36 \\
\hline $08 \ldots$ & 2300 & 19 & 3.3 & 32 & 8 & .41 \\
\hline 08... & 2400 & 18 & 2.1 & 31 & 7 & .34 \\
\hline $09 \ldots$ & 0100 & 18 & 1.9 & 32 & 8 & .39 \\
\hline $09 \ldots$ & 0200 & 18 & 1.8 & 33 & 9 & .44 \\
\hline & 0300 & 18 & 2.0 & 32 & 5 & .24 \\
\hline 09. & 0400 & 17 & 2.1 & 33 & 6 & .28 \\
\hline 09. & 0500 & 17 & 1.8 & 32 & 3 & .14 \\
\hline 09. & 0600 & 17 & 2.4 & 31 & 5 & .23 \\
\hline & 0700 & 16 & 1.6 & 32 & 3 & .13 \\
\hline & 0800 & 16 & 1.2 & 31 & 2 & .09 \\
\hline
\end{tabular}

1 Instantaneous streamflow (discharge) expressed in cubic feet per second.

2 Turbidity value expressed as nephelometric turbidity units.

3 Specific conductance expressed in micromhos per centimeter at $25^{\circ} \mathrm{C}$.

4 Instantaneous suspended-sediment concentration expressed in milligrams per liter.

5 Instantaneous suspended-sediment discharge (10ad) expressed in tons per day. 
Table A-2 Continued. Water-quality data for 1979 and 1980 water years at Stalnaker Run near Bowden, West Virginia (station number 03068607, site 4)

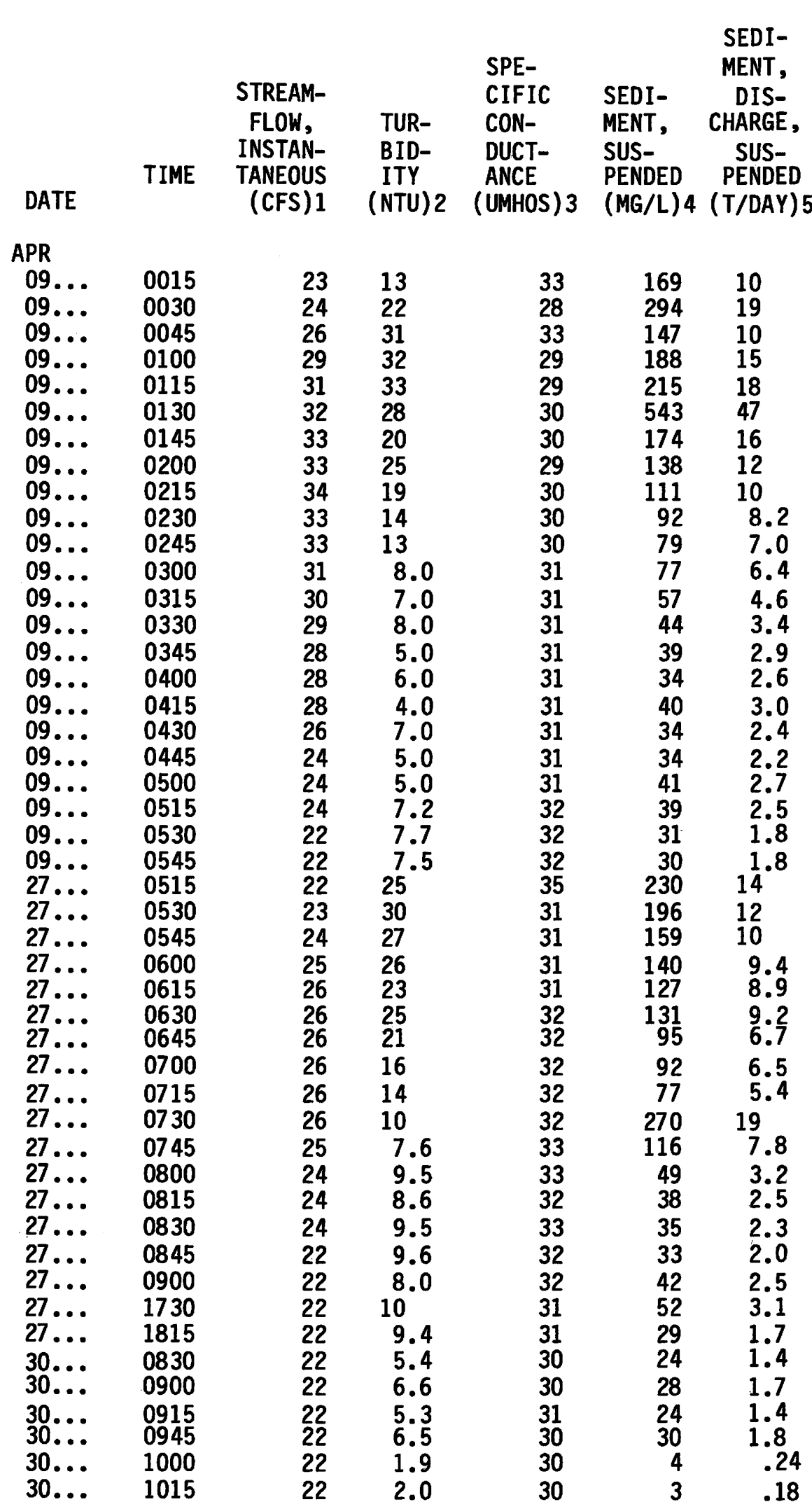




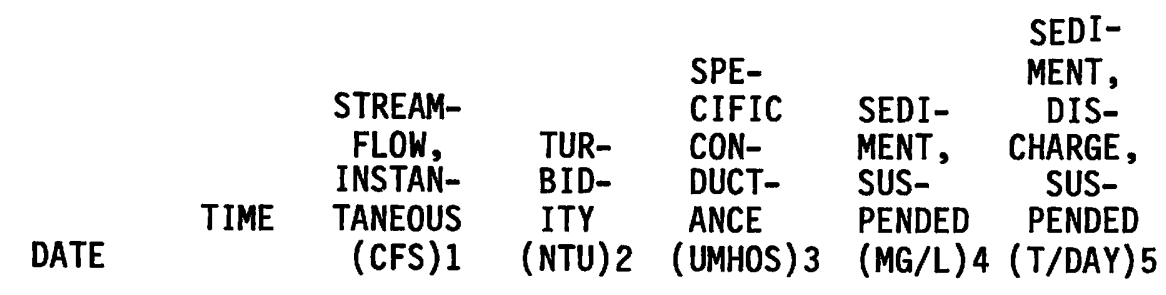

MAY

\begin{tabular}{|c|c|c|c|c|c|c|}
\hline $\begin{array}{l}20 \ldots \\
20 \ldots \\
20 \ldots \\
20 \ldots \\
20 \ldots \\
20 \ldots \\
20 \ldots \\
20 \ldots \\
20 \ldots \\
20 \ldots \\
21 \ldots \\
21 \ldots \\
21 \ldots \\
21 \ldots \\
21 \ldots\end{array}$ & $\begin{array}{l}2145 \\
2200 \\
2215 \\
2230 \\
2245 \\
2300 \\
2315 \\
2330 \\
2345 \\
2400 \\
0015 \\
0030 \\
0045 \\
0100 \\
0115\end{array}$ & $\begin{array}{l}23 \\
26 \\
28 \\
28 \\
28 \\
28 \\
27 \\
26 \\
26 \\
25 \\
24 \\
24 \\
23 \\
22 \\
22\end{array}$ & $\begin{array}{l}80 \\
55 \\
33 \\
40 \\
25 \\
25 \\
19 \\
18 \\
15 \\
9.0 \\
10 \\
10 \\
10 \\
10 \\
10\end{array}$ & $\begin{array}{l}31 \\
31 \\
31 \\
31 \\
31 \\
31 \\
32 \\
32 \\
33 \\
32 \\
32 \\
33 \\
33 \\
33 \\
33\end{array}$ & $\begin{array}{r}448 \\
407 \\
520 \\
240 \\
175 \\
132 \\
110 \\
80 \\
90 \\
65 \\
71 \\
59 \\
59 \\
50 \\
50\end{array}$ & $\begin{array}{l}28 \\
29 \\
39 \\
18 \\
13 \\
10 \\
8.0 \\
5.6 \\
6.3 \\
4.4 \\
4.6 \\
3.8 \\
3.7 \\
3.0 \\
3.0\end{array}$ \\
\hline JUN & & & & & & \\
\hline $\begin{array}{l}10 \ldots \\
10 \ldots\end{array}$ & $\begin{array}{l}0215 \\
0230\end{array}$ & $\begin{array}{l}22 \\
24\end{array}$ & $\begin{array}{l}34 \\
16\end{array}$ & $\begin{array}{l}31 \\
30\end{array}$ & $\begin{array}{l}228 \\
248\end{array}$ & $\begin{array}{l}14 \\
16\end{array}$ \\
\hline $10 \ldots$ & 0245 & 24 & $\begin{array}{l}19 \\
25\end{array}$ & 29 & 201 & $\begin{array}{l}13 \\
13\end{array}$ \\
\hline $10 \ldots$ & 0315 & $\begin{array}{l}<4 \\
24\end{array}$ & 20 & 30 & 139 & 9.0 \\
\hline & 0330 & 24 & 16 & 30 & 109 & 7.1 \\
\hline $10 \ldots$ & 0345 & 24 & 16 & 29 & 110 & 7.1 \\
\hline $10 \ldots$ & 0400 & 25 & 19 & 30 & 90 & 6.1 \\
\hline $10 \ldots$ & 0415 & 25 & 18 & 30 & 129 & 8.7 \\
\hline & 0430 & 25 & 11 & 30 & 77 & 5.2 \\
\hline 10. & 0445 & 24 & 13 & 30 & 202 & 13 \\
\hline $10 .$. & 0500 & 24 & 13 & 30 & 73 & 4.7 \\
\hline 10. & 0515 & $\begin{array}{l}24 \\
25\end{array}$ & 10 & 30 & 58 & 3.8 \\
\hline & $\begin{array}{l}0530 \\
0545\end{array}$ & $\begin{array}{l}25 \\
24\end{array}$ & $\begin{array}{l}10 \\
8.4\end{array}$ & $\begin{array}{l}30 \\
30\end{array}$ & $\begin{array}{l}57 \\
55\end{array}$ & $\begin{array}{l}3.8 \\
3.6\end{array}$ \\
\hline & 0600 & 26 & 14 & 30 & 66 & 4.6 \\
\hline & 0615 & 26 & 18 & 30 & 89 & 6.2 \\
\hline & 0630 & 27 & 18 & 30 & 103 & 7.5 \\
\hline & 06 & 28 & 19 & 30 & 95 & 7.2 \\
\hline & & 28 & 18 & 30 & 108 & 8.2 \\
\hline & 0715 & 28 & 13 & 31 & 84 & 6.4 \\
\hline & & 28 & 17 & 30 & 80 & 6.0 \\
\hline & & 28 & 12 & 30 & & 5.7 \\
\hline & 0800 & 28 & 12 & 31 & 53 & 4.0 \\
\hline
\end{tabular}

1 Instantaneous streamflow (discharge) expressed in cubic feet per second.

2 Turbidity value expressed as nephelometric turbidity units.

3 Specific conductance expressed in micromhos per centimeter at $25^{\circ} \mathrm{C}$.

4 Instantaneous suspended-sediment concentration expressed in milligrams per liter.

5 Instantaneous suspended-sediment discharge (load) expressed in tons per day. 
Table A-2 Continued. Water-quality data for 1979 and 1980 water years at Stalnaker Run near Bowden, West Virginia (station number 03068607, site 4)

\begin{tabular}{|c|c|c|c|c|c|c|}
\hline DATE & TIME & $\begin{array}{l}\text { STREAM- } \\
\text { FLOW, } \\
\text { INSTAN- } \\
\text { TANEOUS } \\
\text { (CFS) } 1\end{array}$ & $\begin{array}{l}\text { TUR- } \\
\text { BID- } \\
\text { ITY } \\
\text { (NTU)2 }\end{array}$ & $\begin{array}{l}\text { SPE- } \\
\text { CIFIC } \\
\text { CON- } \\
\text { DUCT- } \\
\text { ANCE } \\
\text { (UMHOS) } 3\end{array}$ & $\begin{array}{l}\text { SEDI- } \\
\text { MENT, } \\
\text { SUS- } \\
\text { PENDED } \\
\text { (MG/L)4 }\end{array}$ & $\begin{array}{c}\text { SEDI- } \\
\text { MENT, } \\
\text { DIS- } \\
\text { CHARGE, } \\
\text { SUS- } \\
\text { PENDED } \\
(\text { T/DAY } 5\end{array}$ \\
\hline \multicolumn{7}{|l|}{ JUL } \\
\hline 03 & 0400 & 320 & 100 & 42 & 2960 & 2560 \\
\hline $03 .$. & 0415 & 281 & 90 & 36 & 1540 & 1170 \\
\hline $\begin{array}{l}03 \ldots \\
03 \ldots\end{array}$ & $\begin{array}{l}0430 \\
0445\end{array}$ & $\begin{array}{l}256 \\
201\end{array}$ & $\begin{array}{l}65 \\
75\end{array}$ & $\begin{array}{l}34 \\
38\end{array}$ & 1100 & $\begin{array}{l}760 \\
570\end{array}$ \\
\hline $03 . .$. & $\begin{array}{l}4450 \\
0500\end{array}$ & $\begin{array}{l}201 \\
170\end{array}$ & 55 & $\begin{array}{l}38 \\
37\end{array}$ & $\begin{array}{r}1050 \\
820\end{array}$ & 376 \\
\hline $03 \ldots$ & 0515 & 138 & 45 & 36 & 540 & 201 \\
\hline $03 .$. & 0530 & 121 & 45 & 34 & 395 & 129 \\
\hline $03 . .$. & 0545 & 104 & 33 & 34 & 500 & 140 \\
\hline $\begin{array}{l}03 \ldots \\
03 \ldots\end{array}$ & $\begin{array}{l}0600 \\
0615\end{array}$ & $\begin{array}{l}87 \\
83\end{array}$ & 24 & 34 & 237 & 56 \\
\hline $\begin{array}{l}03 . . . \\
03 . .\end{array}$ & 0630 & $\begin{array}{l}83 \\
75\end{array}$ & $\begin{array}{l}29 \\
24\end{array}$ & $\begin{array}{l}33 \\
33\end{array}$ & $\begin{array}{l}267 \\
256\end{array}$ & $\begin{array}{l}60 \\
52\end{array}$ \\
\hline $03 \ldots$ & 0645 & 67 & 24 & 33 & 340 & 62 \\
\hline 03... & 0700 & 61 & 13 & 33 & 146 & 24 \\
\hline 03.. & 0715 & 56 & 14 & 33 & 157 & 24 \\
\hline 03.. & 0730 & 52 & 16 & 32 & 123 & 17 \\
\hline 03.. & 0745 & 47 & 5.5 & 32 & 88 & 11 \\
\hline 03... & 0800 & 44 & 12 & 32 & 109 & 13 \\
\hline 03. & 0815 & 41 & 4.4 & 31 & 95 & 11 \\
\hline 03. & 0830 & 38 & 5.3 & 32 & 114 & 12 \\
\hline 03. & 0845 & 36 & 1.9 & 32 & 62 & 6.0 \\
\hline 03. & 0900 & 35 & 5.5 & 32 & 99 & 9.4 \\
\hline 03. & 0915 & 33 & 2.2 & 31 & 82 & 7.3 \\
\hline 08. & 1630 & 21 & 45 & 32 & -- & -- \\
\hline 08. & 1645 & 30 & 60 & 30 & 665 & 54 \\
\hline 08. & 1700 & 36 & 50 & 29 & 257 & 25 \\
\hline 08. & 1715 & 40 & 50 & 28 & 339 & 37 \\
\hline 08. & 1730 & 42 & 27 & 29 & 116 & 13 \\
\hline 08 . & 1745 & 44 & 13 & 28 & 124 & 15 \\
\hline 08 . & 1800 & 42 & 11 & 29 & 110 & 12 \\
\hline & 1815 & 40 & 10 & 29 & 2310 & 249 \\
\hline 08. & 1830 & 39 & 12 & 29 & 1960 & 206 \\
\hline 08. & 1845 & $\begin{array}{l}38 \\
27\end{array}$ & 7.5 & 29 & 115 & 12 \\
\hline 08. & $\begin{array}{l}1900 \\
1915\end{array}$ & $\begin{array}{l}37 \\
36\end{array}$ & $\begin{array}{l}5.3 \\
4.2\end{array}$ & $\begin{array}{l}29 \\
29\end{array}$ & $\begin{array}{r}137 \\
99\end{array}$ & $\begin{array}{c}14 \\
9.6\end{array}$ \\
\hline & 1930 & 35 & 4.6 & 30 & 108 & 10 \\
\hline & 1945 & 33 & 5.9 & 29 & 30 & 2.7 \\
\hline & 2000 & 32 & 4.8 & 29 & 28 & 2.4 \\
\hline & 2015 & 31 & 4.7 & 29 & 28 & 2.3 \\
\hline & 2030 & 30 & 6.2 & 29 & 31 & 2.5 \\
\hline & 2045 & 30 & 4.3 & 29 & 28 & 2.3 \\
\hline & 2100 & $\begin{array}{l}29 \\
? 0\end{array}$ & 4.1 & 30 & 23 & 1.8 \\
\hline & $\begin{array}{l}2115 \\
2130\end{array}$ & $\begin{array}{l}28 \\
27\end{array}$ & $\begin{array}{l}3.9 \\
8.6\end{array}$ & $\begin{array}{l}30 \\
29\end{array}$ & $\begin{array}{l}21 \\
26\end{array}$ & $\begin{array}{l}2.0 \\
1.9\end{array}$ \\
\hline & 2145 & 26 & $\begin{array}{l}0.0 \\
3.7\end{array}$ & 29 & $\begin{array}{l}20 \\
13\end{array}$ & .91 \\
\hline & 2200 & 26 & 2. & 29 & 16 & 1.1 \\
\hline & 2215 & & & 29 & 10 & .70 \\
\hline
\end{tabular}




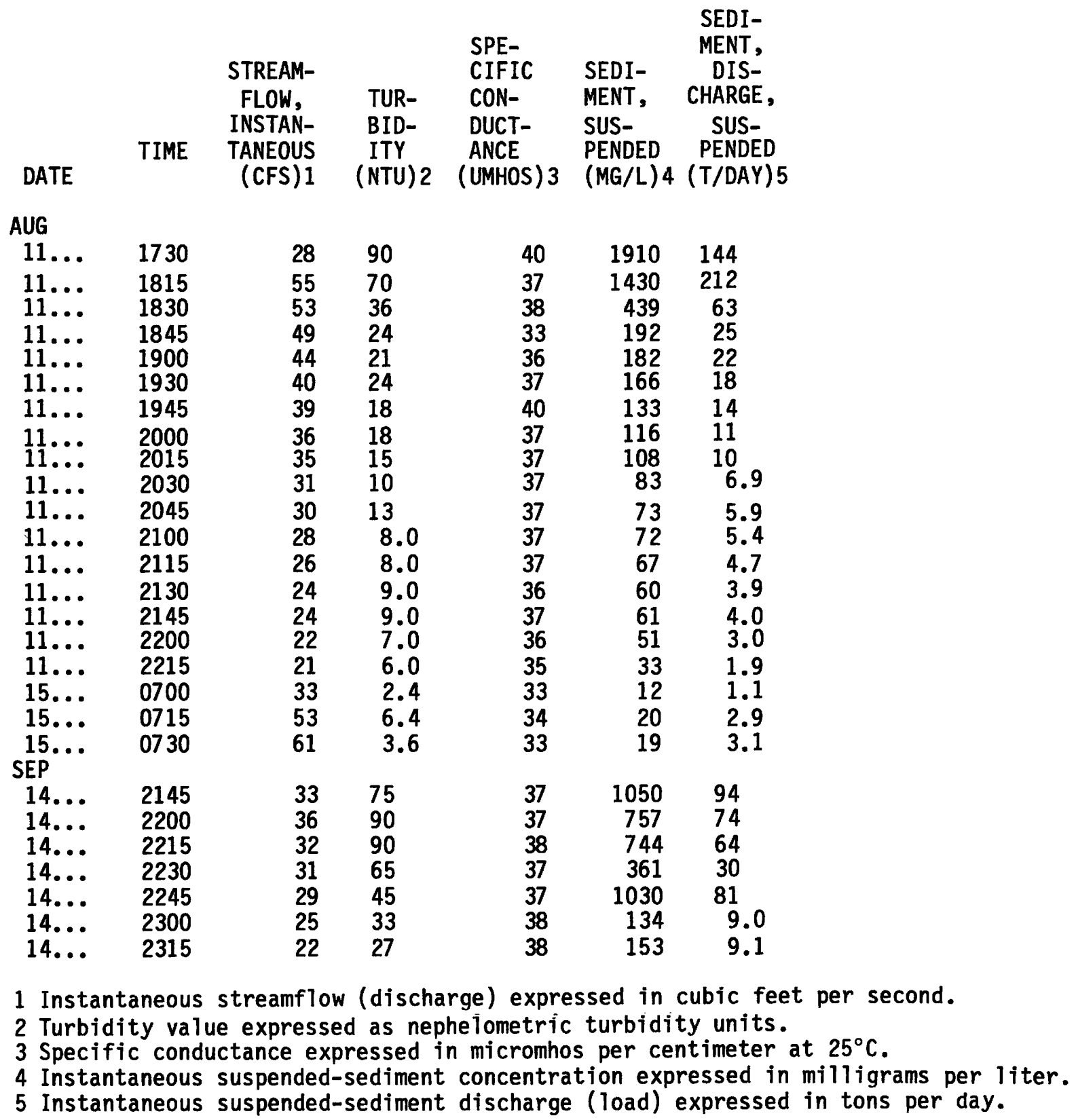


Table B-1. Daily precipitation July 1975 to September 1980 at South Spring at Bowden, West Virginia (station number 03068710, site 8)

RAINFALL, ACCUMULATED (INCHES), WATER YEAR OCTOBER 1974 TO SEPTEMBER 1975

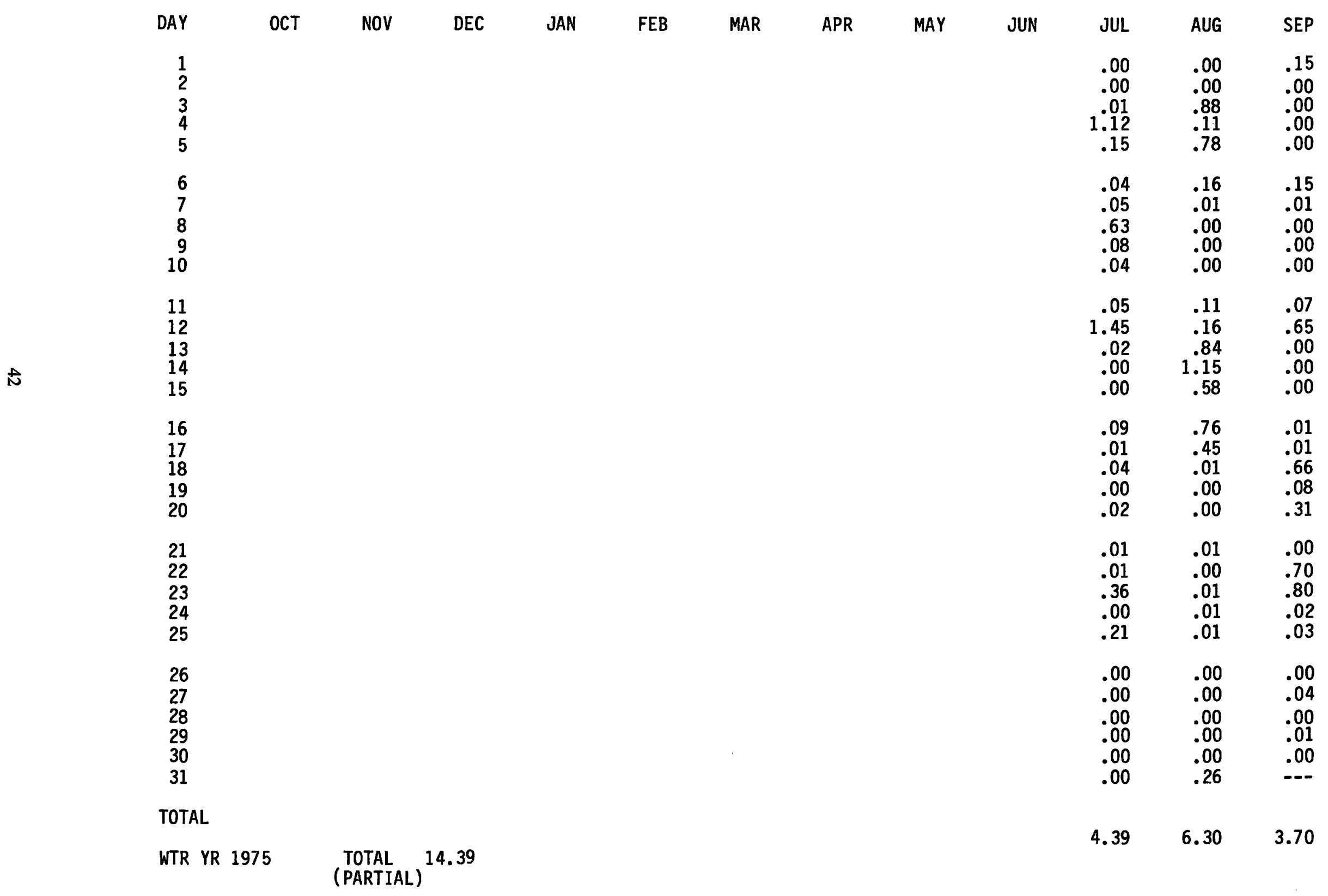


RAINFALL, ACCUMULATED (INCHES), WATER YEAR OCTOBER 1975 TO SEPTEMBER 1976

\begin{tabular}{|c|c|c|c|c|c|c|c|c|c|c|c|c|}
\hline DAY & OCT & NOV & DEC & JAN & FEB & MAR & APR & MAY & JUN & JUL & AUG & SEP \\
\hline $\begin{array}{l}1 \\
2 \\
3 \\
4 \\
5\end{array}$ & $\begin{array}{l}.05 \\
.24 \\
.00 \\
.01 \\
.00\end{array}$ & $\begin{array}{l}.00 \\
.01 \\
.00 \\
.00 \\
.00\end{array}$ & $\begin{array}{l}.20 \\
.00 \\
.01 \\
.09 \\
.00\end{array}$ & $\begin{array}{l}.03 \\
.19 \\
.39 \\
.00 \\
.00\end{array}$ & $\begin{array}{l}.33 \\
.00 \\
.15 \\
.26 \\
.26\end{array}$ & $\begin{array}{l}.00 \\
.00 \\
.02 \\
.00 \\
.03\end{array}$ & $\begin{array}{l}.07 \\
.07 \\
.47 \\
.13 \\
.02\end{array}$ & $\begin{array}{l}.77 \\
.02 \\
.22 \\
.00 \\
.01\end{array}$ & $\begin{array}{l}.16 \\
.01 \\
.01 \\
.00 \\
.00\end{array}$ & $\begin{array}{l}.00 \\
.00 \\
.00 \\
.00 \\
.17\end{array}$ & $\begin{array}{l}.00 \\
.00 \\
.01 \\
.00 \\
.00\end{array}$ & $\begin{array}{l}.13 \\
.41 \\
.00 \\
.00 \\
.03\end{array}$ \\
\hline $\begin{array}{r}6 \\
7 \\
8 \\
9 \\
10\end{array}$ & $\begin{array}{l}.00 \\
.00 \\
.06 \\
.33 \\
.54\end{array}$ & $\begin{array}{l}.00 \\
.04 \\
.01 \\
.01 \\
.16\end{array}$ & $\begin{array}{l}.34 \\
.00 \\
.01 \\
.13 \\
.01\end{array}$ & $\begin{array}{l}.01 \\
.04 \\
.03 \\
.00 \\
.00\end{array}$ & $\begin{array}{l}.12 \\
.00 \\
.00 \\
.02 \\
.02\end{array}$ & $\begin{array}{l}.00 \\
.00 \\
.00 \\
.00 \\
.59\end{array}$ & $\begin{array}{l}.01 \\
.00 \\
.00 \\
.00 \\
.01\end{array}$ & $\begin{array}{l}.00 \\
.06 \\
.00 \\
.00 \\
.00\end{array}$ & $\begin{array}{l}.00 \\
.00 \\
.00 \\
.00 \\
.00\end{array}$ & $\begin{array}{l}.11 \\
.02 \\
.46 \\
.11 \\
.05\end{array}$ & $\begin{array}{l}.03 \\
.24 \\
.01 \\
.00 \\
.00\end{array}$ & $\begin{array}{r}.00 \\
.00 \\
.00 \\
.13 \\
1.06\end{array}$ \\
\hline $\begin{array}{l}11 \\
12 \\
13 \\
14 \\
15\end{array}$ & $\begin{array}{l}.19 \\
.00 \\
.01 \\
.00 \\
.00\end{array}$ & $\begin{array}{r}.00 \\
1.25 \\
.01 \\
.00 \\
.12\end{array}$ & $\begin{array}{l}.02 \\
.19 \\
.14 \\
.01 \\
.28\end{array}$ & $\begin{array}{l}.46 \\
.00 \\
.50 \\
.01 \\
.01\end{array}$ & $\begin{array}{l}.41 \\
.00 \\
.89 \\
.00 \\
.00\end{array}$ & $\begin{array}{l}.18 \\
.03 \\
.16 \\
.04 \\
.00\end{array}$ & $\begin{array}{l}.10 \\
.02 \\
.00 \\
.00 \\
.00\end{array}$ & $\begin{array}{l}.13 \\
.00 \\
.01 \\
.00 \\
.07\end{array}$ & $\begin{array}{l}.00 \\
.00 \\
.31 \\
.02 \\
.00\end{array}$ & $\begin{array}{r}1.16 \\
.17 \\
.00 \\
.01 \\
.61\end{array}$ & $\begin{array}{l}.00 \\
.01 \\
.00 \\
.37 \\
.21\end{array}$ & $\begin{array}{l}.00 \\
.00 \\
.00 \\
.00 \\
.83\end{array}$ \\
\hline $\begin{array}{l}16 \\
17 \\
18 \\
19 \\
20\end{array}$ & $\begin{array}{r}.02 \\
1.19 \\
.06 \\
.03 \\
.08\end{array}$ & $\begin{array}{l}.08 \\
.01 \\
.00 \\
.00 \\
.00\end{array}$ & $\begin{array}{l}.27 \\
.01 \\
.00 \\
.00 \\
.02\end{array}$ & $\begin{array}{l}.01 \\
.00 \\
.00 \\
.06 \\
.04\end{array}$ & $\begin{array}{l}.06 \\
.20 \\
.17 \\
.01 \\
.00\end{array}$ & $\begin{array}{l}.45 \\
.03 \\
.06 \\
.00 \\
.10\end{array}$ & $\begin{array}{l}.00 \\
.00 \\
.00 \\
.00 \\
.29\end{array}$ & $\begin{array}{l}.46 \\
.12 \\
.45 \\
.05 \\
.01\end{array}$ & $\begin{array}{l}.47 \\
.03 \\
.05 \\
.55 \\
.65\end{array}$ & $\begin{array}{l}.67 \\
.01 \\
.00 \\
.00 \\
.00\end{array}$ & $\begin{array}{l}.01 \\
.00 \\
.00 \\
.00 \\
.00\end{array}$ & $\begin{array}{l}.02 \\
.31 \\
.09 \\
.00 \\
.27\end{array}$ \\
\hline $\begin{array}{l}21 \\
22 \\
23 \\
24 \\
25\end{array}$ & $\begin{array}{l}.02 \\
.00 \\
.00 \\
.01 \\
.00\end{array}$ & $\begin{array}{l}.14 \\
.00 \\
.00 \\
.00 \\
.00\end{array}$ & $\begin{array}{l}.00 \\
.00 \\
.00 \\
.04 \\
.12\end{array}$ & $\begin{array}{l}.00 \\
.00 \\
.02 \\
.00 \\
.02\end{array}$ & $\begin{array}{l}.11 \\
.49 \\
.04 \\
.05 \\
.00\end{array}$ & $\begin{array}{l}.98 \\
.01 \\
.01 \\
.00 \\
.11\end{array}$ & $\begin{array}{l}.02 \\
.35 \\
.00 \\
.02 \\
.53\end{array}$ & $\begin{array}{l}.00 \\
.00 \\
.00 \\
.00 \\
.16\end{array}$ & $\begin{array}{l}.22 \\
.02 \\
.00 \\
.11 \\
.31\end{array}$ & $\begin{array}{r}.09 \\
.43 \\
1.46 \\
.61 \\
.01\end{array}$ & $\begin{array}{l}.00 \\
.00 \\
.00 \\
.00 \\
.00\end{array}$ & $\begin{array}{l}.40 \\
.00 \\
.01 \\
.00 \\
.00\end{array}$ \\
\hline $\begin{array}{l}26 \\
27 \\
28 \\
29 \\
30 \\
31\end{array}$ & $\begin{array}{l}.06 \\
.02 \\
.00 \\
.16 \\
.04 \\
.00\end{array}$ & $\begin{array}{l}.00 \\
.22 \\
.00 \\
.01 \\
.08 \\
---\end{array}$ & $\begin{array}{r}.32 \\
.00 \\
.03 \\
.05 \\
.40 \\
1.14\end{array}$ & $\begin{array}{l}.11 \\
.23 \\
.01 \\
.01 \\
.00 \\
.01\end{array}$ & $\begin{array}{l}.00 \\
.00 \\
.00 \\
.00 \\
-0- \\
---\end{array}$ & $\begin{array}{l}.01 \\
.22 \\
.00 \\
.24 \\
.04 \\
.37\end{array}$ & $\begin{array}{l}.11 \\
.00 \\
.00 \\
.00 \\
.01 \\
---\end{array}$ & $\begin{array}{l}.00 \\
.00 \\
.01 \\
.06 \\
.04 \\
.04\end{array}$ & $\begin{array}{l}.04 \\
.00 \\
.01 \\
.00 \\
.09 \\
---\end{array}$ & $\begin{array}{l}.00 \\
.00 \\
.68 \\
.00 \\
.01 \\
.10\end{array}$ & $\begin{array}{l}.65 \\
.21 \\
.04 \\
.02 \\
.00 \\
.00\end{array}$ & $\begin{array}{r}.08 \\
1.08 \\
.03 \\
.00 \\
.90 \\
---\end{array}$ \\
\hline TOTAL & 3.12 & 2.15 & 3.83 & 2.19 & 3.59 & 3.68 & 2.23 & 2.93 & 3.06 & 6.94 & 1.81 & 5.78 \\
\hline WTR Y Y & 1976 & TOTAL & 41.31 & & & & & & & & & \\
\hline
\end{tabular}


Table B-1 Continued. Daily precipitation July 1975 to September 1980 at South Spring at Bowden, West Virginia (station number 03068710, site 8)

RAINFALL, ACCUMULATED (INCHES), WATER YEAR OCTOBER 1976 TO SEPTEMBER 1977

\begin{tabular}{|c|c|c|c|c|c|c|c|c|c|c|c|c|}
\hline DAY & OCT & NOV & DEC & JAN & FEB & MAR & APR & MAY & JUN & JUL & AUG & SEP \\
\hline $\begin{array}{l}1 \\
2 \\
3 \\
4 \\
5\end{array}$ & $\begin{array}{l}.73 \\
.44 \\
.11 \\
.00 \\
.00\end{array}$ & $\begin{array}{l}.04 \\
.01 \\
.00 \\
.03 \\
.00\end{array}$ & $\begin{array}{l}.09 \\
.00 \\
.01 \\
.01 \\
.00\end{array}$ & $\begin{array}{l}.01 \\
.00 \\
.00 \\
.00 \\
.00\end{array}$ & $\begin{array}{l}.00 \\
.00 \\
.02 \\
.01 \\
.00\end{array}$ & $\begin{array}{l}.00 \\
.01 \\
.10 \\
.43 \\
.00\end{array}$ & $\begin{array}{r}.01 \\
.21 \\
.00 \\
1.31 \\
.37\end{array}$ & $\begin{array}{l}.00 \\
.16 \\
.00 \\
.11 \\
.16\end{array}$ & $\begin{array}{l}.03 \\
.11 \\
.02 \\
.00 \\
.03\end{array}$ & $\begin{array}{l}.03 \\
.00 \\
.00 \\
.00 \\
.30\end{array}$ & $\begin{array}{l}.02 \\
.00 \\
.00 \\
.00 \\
.16\end{array}$ & $\begin{array}{l}.01 \\
.04 \\
.25 \\
.01 \\
.00\end{array}$ \\
\hline $\begin{array}{r}6 \\
7 \\
8 \\
9 \\
10\end{array}$ & $\begin{array}{r}.00 \\
.61 \\
1.01 \\
1.93 \\
.07\end{array}$ & $\begin{array}{l}.00 \\
.00 \\
.00 \\
.02 \\
.11\end{array}$ & $\begin{array}{l}.18 \\
.80 \\
.00 \\
.01 \\
.00\end{array}$ & $\begin{array}{l}.00 \\
.00 \\
.00 \\
.00 \\
.00\end{array}$ & $\begin{array}{l}.00 \\
.00 \\
.11 \\
.01 \\
.01\end{array}$ & $\begin{array}{l}.00 \\
.00 \\
.00 \\
.00 \\
.00\end{array}$ & $\begin{array}{l}.05 \\
.16 \\
.00 \\
.00 \\
.02\end{array}$ & $\begin{array}{l}.22 \\
.94 \\
.00 \\
.00 \\
.00\end{array}$ & $\begin{array}{r}.18 \\
.01 \\
.45 \\
1.30 \\
.01\end{array}$ & $\begin{array}{l}.01 \\
.01 \\
.11 \\
.00 \\
.17\end{array}$ & $\begin{array}{l}.15 \\
.16 \\
.76 \\
.00 \\
.26\end{array}$ & $\begin{array}{l}.00 \\
.53 \\
.01 \\
.00 \\
.00\end{array}$ \\
\hline $\begin{array}{l}11 \\
12 \\
13 \\
14 \\
15\end{array}$ & $\begin{array}{l}.00 \\
.00 \\
.00 \\
.00 \\
.07\end{array}$ & $\begin{array}{l}.00 \\
.00 \\
.00 \\
.07 \\
.21\end{array}$ & $\begin{array}{l}.43 \\
.31 \\
.00 \\
.00 \\
.00\end{array}$ & $\begin{array}{l}.01 \\
.01 \\
.00 \\
.37 \\
.00\end{array}$ & $\begin{array}{l}.00 \\
.04 \\
.12 \\
.00 \\
.00\end{array}$ & $\begin{array}{r}.01 \\
.14 \\
1.01 \\
.00 \\
.02\end{array}$ & $\begin{array}{l}.01 \\
.01 \\
.00 \\
.12 \\
.00\end{array}$ & $\begin{array}{l}.00 \\
.00 \\
.12 \\
.00 \\
.00\end{array}$ & $\begin{array}{l}.00 \\
.00 \\
.00 \\
.00 \\
.00\end{array}$ & $\begin{array}{l}.95 \\
.44 \\
.38 \\
.02 \\
.00\end{array}$ & $\begin{array}{r}.01 \\
1.30 \\
.20 \\
1.00 \\
.01\end{array}$ & $\begin{array}{l}.00 \\
.00 \\
.00 \\
.44 \\
.06\end{array}$ \\
\hline $\begin{array}{l}16 \\
17 \\
18 \\
19 \\
20\end{array}$ & $\begin{array}{l}.06 \\
.18 \\
.01 \\
.02 \\
.99\end{array}$ & $\begin{array}{l}.00 \\
.00 \\
.00 \\
.01 \\
.00\end{array}$ & $\begin{array}{l}.05 \\
.00 \\
.00 \\
.01 \\
.30\end{array}$ & $\begin{array}{l}.01 \\
.02 \\
.00 \\
.00 \\
.00\end{array}$ & $\begin{array}{l}.00 \\
.00 \\
.07 \\
.08 \\
.01\end{array}$ & $\begin{array}{l}.00 \\
.00 \\
.45 \\
.00 \\
.21\end{array}$ & $\begin{array}{r}.00 \\
.00 \\
.00 \\
.02 \\
1.43\end{array}$ & $\begin{array}{l}.00 \\
.00 \\
.01 \\
.08 \\
.00\end{array}$ & $\begin{array}{l}.64 \\
.00 \\
.08 \\
.03 \\
.44\end{array}$ & $\begin{array}{l}.00 \\
.00 \\
.00 \\
.00 \\
.00\end{array}$ & $\begin{array}{l}.00 \\
.38 \\
.01 \\
.00 \\
.00\end{array}$ & $\begin{array}{l}.10 \\
.10 \\
.00 \\
.40 \\
.62\end{array}$ \\
\hline $\begin{array}{l}21 \\
22 \\
23 \\
24 \\
25\end{array}$ & $\begin{array}{l}.07 \\
.00 \\
.10 \\
.79 \\
.33\end{array}$ & $\begin{array}{l}.00 \\
.00 \\
.00 \\
.00 \\
.23\end{array}$ & $\begin{array}{l}.00 \\
.02 \\
.00 \\
.02 \\
.03\end{array}$ & $\begin{array}{l}.00 \\
.00 \\
.01 \\
.02 \\
.00\end{array}$ & $\begin{array}{l}.00 \\
.15 \\
.01 \\
.40 \\
.02\end{array}$ & $\begin{array}{l}.01 \\
.59 \\
.07 \\
.00 \\
.00\end{array}$ & $\begin{array}{l}.02 \\
.00 \\
.06 \\
.16 \\
.01\end{array}$ & $\begin{array}{l}.00 \\
.00 \\
.47 \\
.00 \\
.00\end{array}$ & $\begin{array}{r}.00 \\
.00 \\
.02 \\
.02 \\
1.67\end{array}$ & $\begin{array}{r}.94 \\
.17 \\
.00 \\
.00 \\
1.77\end{array}$ & $\begin{array}{l}.00 \\
.00 \\
.00 \\
.59 \\
.01\end{array}$ & $\begin{array}{l}.00 \\
.01 \\
.00 \\
.00 \\
.10\end{array}$ \\
\hline $\begin{array}{l}26 \\
27 \\
28 \\
29 \\
30 \\
31\end{array}$ & $\begin{array}{l}.00 \\
.00 \\
.15 \\
.01 \\
.40 \\
.46\end{array}$ & $\begin{array}{l}.01 \\
.05 \\
.13 \\
.07 \\
.00 \\
---\end{array}$ & $\begin{array}{l}.00 \\
.00 \\
.34 \\
.00 \\
.00 \\
.00\end{array}$ & $\begin{array}{l}.00 \\
.00 \\
.10 \\
.00 \\
.00 \\
.00\end{array}$ & $\begin{array}{l}.00 \\
.01 \\
.00 \\
--- \\
---\end{array}$ & $\begin{array}{l}.00 \\
.01 \\
.40 \\
.02 \\
.06 \\
.16\end{array}$ & $\begin{array}{l}.26 \\
.20 \\
.23 \\
.01 \\
.00 \\
---\end{array}$ & $\begin{array}{l}.01 \\
.00 \\
.00 \\
.00 \\
.00 \\
.44\end{array}$ & $\begin{array}{l}.00 \\
.19 \\
.06 \\
.48 \\
.01 \\
---\end{array}$ & $\begin{array}{l}.01 \\
.01 \\
.00 \\
.16 \\
.07 \\
.00\end{array}$ & $\begin{array}{r}.00 \\
.00 \\
.00 \\
.00 \\
1.07 \\
.02\end{array}$ & $\begin{array}{l}.16 \\
.16 \\
.01 \\
.00 \\
.00 \\
-.-\end{array}$ \\
\hline TOTAL & 8.54 & 0.99 & 2.61 & 0.56 & 1.07 & 3.70 & 4.67 & 2.72 & 5.78 & 5.55 & 6.11 & 3.01 \\
\hline WTR YR & 977 & TOTAL & 45.31 & & & & & & & & & \\
\hline
\end{tabular}


RAINFALL, ACCUMULATED (INCHES), WATER YEAR OCTOBER 1977 TO SEPTEMBER 1978

\begin{tabular}{|c|c|c|c|c|c|c|c|c|c|c|c|c|}
\hline DAY & OCT & NOV & DEC & JAN & FEB & MAR & APR & MAY & JUN & JUL & AUG & SEP \\
\hline $\begin{array}{l}1 \\
2 \\
3 \\
4 \\
5\end{array}$ & $\begin{array}{l}.69 \\
.19 \\
.09 \\
.00 \\
.01\end{array}$ & $\begin{array}{l}.00 \\
.00 \\
.00 \\
.00 \\
.09\end{array}$ & $\begin{array}{l}.00 \\
.00 \\
.20 \\
.01 \\
.39\end{array}$ & $\begin{array}{l}.14 \\
.00 \\
.00 \\
.06 \\
.00\end{array}$ & $\begin{array}{l}.01 \\
.00 \\
.03 \\
.07 \\
.01\end{array}$ & $\begin{array}{l}.06 \\
.08 \\
.00 \\
.00 \\
.05\end{array}$ & $\begin{array}{l}.00 \\
.05 \\
.04 \\
.31 \\
.01\end{array}$ & $\begin{array}{l}.00 \\
.00 \\
.00 \\
.77 \\
.45\end{array}$ & $\begin{array}{l}.00 \\
.07 \\
.73 \\
.00 \\
.14\end{array}$ & $\begin{array}{r}.00 \\
1.22 \\
2.51 \\
.05 \\
.02\end{array}$ & $\begin{array}{r}.01 \\
.00 \\
1.51 \\
.23 \\
.31\end{array}$ & $\begin{array}{l}.02 \\
.00 \\
.05 \\
.00 \\
.00\end{array}$ \\
\hline $\begin{array}{r}6 \\
7 \\
8 \\
9 \\
10\end{array}$ & $\begin{array}{l}.51 \\
.00 \\
.51 \\
.97 \\
.00\end{array}$ & $\begin{array}{l}.01 \\
.03 \\
.09 \\
.01 \\
.43\end{array}$ & $\begin{array}{l}.15 \\
.00 \\
.08 \\
.14 \\
.00\end{array}$ & $\begin{array}{l}.09 \\
.02 \\
.34 \\
.00 \\
.00\end{array}$ & $\begin{array}{l}.00 \\
.00 \\
.12 \\
.00 \\
.00\end{array}$ & $\begin{array}{l}.01 \\
.16 \\
.08 \\
.00 \\
.00\end{array}$ & $\begin{array}{l}.32 \\
.19 \\
.00 \\
.00 \\
.00\end{array}$ & $\begin{array}{l}.06 \\
.00 \\
.73 \\
.09 \\
.00\end{array}$ & $\begin{array}{l}.01 \\
.50 \\
.69 \\
.17 \\
.01\end{array}$ & $\begin{array}{l}.00 \\
.00 \\
.47 \\
.01 \\
.18\end{array}$ & $\begin{array}{l}.20 \\
.48 \\
.07 \\
.00 \\
.01\end{array}$ & $\begin{array}{l}.00 \\
.00 \\
.00 \\
.00 \\
.00\end{array}$ \\
\hline $\begin{array}{l}11 \\
12 \\
13 \\
14 \\
15\end{array}$ & $\begin{array}{l}.01 \\
.01 \\
.00 \\
.02 \\
.01\end{array}$ & $\begin{array}{l}.01 \\
.02 \\
.14 \\
.05 \\
.01\end{array}$ & $\begin{array}{l}.00 \\
.03 \\
.04 \\
.52 \\
.01\end{array}$ & $\begin{array}{l}.00 \\
.02 \\
.11 \\
.00 \\
.00\end{array}$ & $\begin{array}{l}.00 \\
.00 \\
.00 \\
.00 \\
.12\end{array}$ & $\begin{array}{l}.00 \\
.11 \\
.00 \\
.22 \\
.00\end{array}$ & $\begin{array}{l}.63 \\
.01 \\
.00 \\
.00 \\
.00\end{array}$ & $\begin{array}{r}.00 \\
.00 \\
1.33 \\
.16 \\
.05\end{array}$ & $\begin{array}{l}.00 \\
.00 \\
.03 \\
.00 \\
.00\end{array}$ & $\begin{array}{r}.01 \\
.01 \\
.00 \\
1.37 \\
.00\end{array}$ & $\begin{array}{l}.72 \\
.02 \\
.15 \\
.02 \\
.00\end{array}$ & $\begin{array}{l}.05 \\
.43 \\
.03 \\
.00 \\
.17\end{array}$ \\
\hline $\begin{array}{l}16 \\
17 \\
18 \\
19 \\
20\end{array}$ & $\begin{array}{r}1.03 \\
.01 \\
.01 \\
.50 \\
.01\end{array}$ & $\begin{array}{l}.07 \\
.25 \\
.00 \\
.00 \\
.00\end{array}$ & $\begin{array}{l}.00 \\
.03 \\
.16 \\
.00 \\
.18\end{array}$ & $\begin{array}{l}.00 \\
.00 \\
.00 \\
.00 \\
.00\end{array}$ & $\begin{array}{l}.06 \\
.00 \\
.02 \\
.08 \\
.02\end{array}$ & $\begin{array}{l}.03 \\
.01 \\
.15 \\
.15 \\
.02\end{array}$ & $\begin{array}{l}.00 \\
.00 \\
.18 \\
.52 \\
.42\end{array}$ & $\begin{array}{l}.32 \\
.09 \\
.04 \\
.02 \\
.00\end{array}$ & $\begin{array}{l}.00 \\
.02 \\
.00 \\
.00 \\
.71\end{array}$ & $\begin{array}{l}.12 \\
.02 \\
.01 \\
.01 \\
.01\end{array}$ & $\begin{array}{l}.00 \\
.01 \\
.00 \\
.00 \\
.00\end{array}$ & $\begin{array}{l}.57 \\
.02 \\
.00 \\
.01 \\
.00\end{array}$ \\
\hline $\begin{array}{l}21 \\
22 \\
23 \\
24 \\
25\end{array}$ & $\begin{array}{l}.00 \\
.00 \\
.00 \\
.00 \\
.00\end{array}$ & $\begin{array}{l}.14 \\
.57 \\
.12 \\
.11 \\
.15\end{array}$ & $\begin{array}{l}.13 \\
.00 \\
.09 \\
.13 \\
.27\end{array}$ & $\begin{array}{l}.00 \\
.00 \\
.01 \\
.17 \\
.89\end{array}$ & $\begin{array}{l}.00 \\
.00 \\
.04 \\
.00 \\
.00\end{array}$ & $\begin{array}{l}.16 \\
.01 \\
.02 \\
.03 \\
.85\end{array}$ & $\begin{array}{l}.33 \\
.02 \\
.00 \\
.00 \\
.20\end{array}$ & $\begin{array}{l}.00 \\
.00 \\
.32 \\
.63 \\
.04\end{array}$ & $\begin{array}{l}.63 \\
.09 \\
.02 \\
.00 \\
.00\end{array}$ & $\begin{array}{l}.00 \\
.00 \\
.00 \\
.15 \\
.33\end{array}$ & $\begin{array}{l}.01 \\
.00 \\
.01 \\
.00 \\
.01\end{array}$ & $\begin{array}{l}.00 \\
.15 \\
.01 \\
.00 \\
.01\end{array}$ \\
\hline $\begin{array}{l}26 \\
27 \\
28 \\
29 \\
30 \\
31\end{array}$ & $\begin{array}{l}.29 \\
.00 \\
.01 \\
.00 \\
.00 \\
.00\end{array}$ & $\begin{array}{l}.06 \\
.17 \\
.03 \\
.57 \\
.48 \\
---\end{array}$ & $\begin{array}{l}.00 \\
.00 \\
.00 \\
.01 \\
.02 \\
.00\end{array}$ & $\begin{array}{l}.40 \\
.00 \\
.12 \\
.00 \\
.00 \\
.00\end{array}$ & \begin{tabular}{l}
.00 \\
.00 \\
.00 \\
.0 \\
\hdashline- \\
---
\end{tabular} & $\begin{array}{l}.74 \\
.06 \\
.05 \\
.00 \\
.01 \\
.00\end{array}$ & $\begin{array}{l}.33 \\
.00 \\
.00 \\
.00 \\
.00 \\
--.\end{array}$ & $\begin{array}{l}.01 \\
.00 \\
.00 \\
.00 \\
.03 \\
.17\end{array}$ & $\begin{array}{r}1.80 \\
.65 \\
.00 \\
.00 \\
.00 \\
---\end{array}$ & $\begin{array}{r}.00 \\
.79 \\
.01 \\
.01 \\
.85 \\
1.14\end{array}$ & $\begin{array}{l}.01 \\
.68 \\
.59 \\
.00 \\
.16 \\
.08\end{array}$ & $\begin{array}{l}.00 \\
.00 \\
.00 \\
.00 \\
.00 \\
-0 .\end{array}$ \\
\hline TOTAL & 4.88 & 3.61 & 2.59 & 2.37 & 0.58 & 3.06 & 3.56 & 5.31 & 6.27 & 9.30 & 5.29 & 1.52 \\
\hline WTR YR & & TOTAL & 48.34 & & & & & & & & & \\
\hline
\end{tabular}


Table B-1 Continued. Daily precipitation July 1975 to September 1980 at South Spring at Bowden, West Virginia (station number 03068710, site 8) RAINFALL, ACCUMULATED (INCHES), WATER YEAR OCTOBER 1978 TO SEPTEMBER 1979

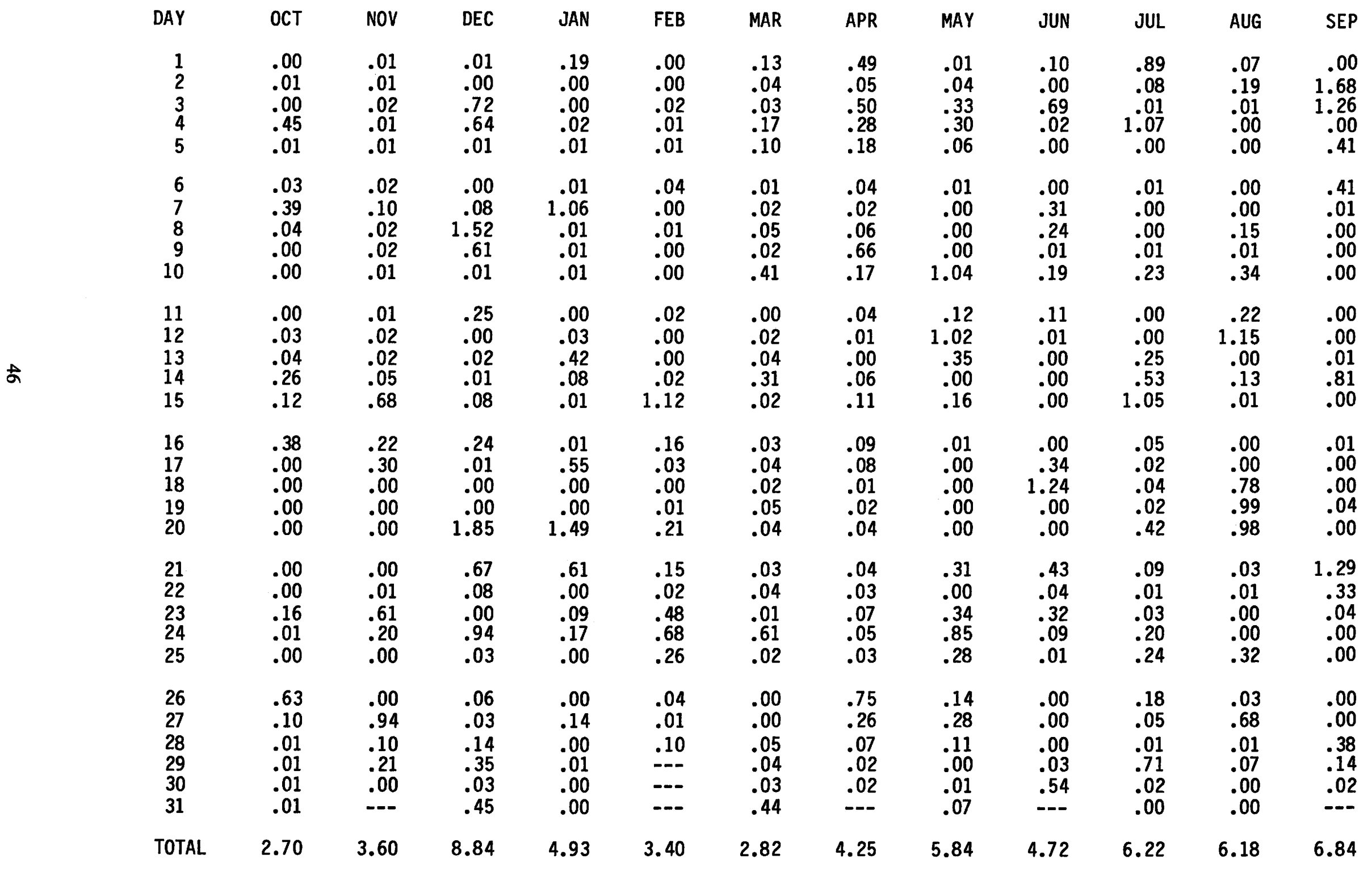

$\begin{array}{lll}\text { WTR YR } 1979 & \text { TOTAL } & 60.34\end{array}$ 
RAINFALL, ACCUMULATED (INCHES), WATER YEAR OCTOBER 1979 TO SEPTEMBER 1980 sis th. THA it:":

\begin{tabular}{|c|c|c|c|c|c|c|c|c|c|c|c|c|}
\hline DAY & OCT & NOV & DEC & JAN & FEB & MAR & APR & MAY & JUN & JUL & AUG & SEP \\
\hline $\begin{array}{l}1 \\
2 \\
3 \\
4 \\
5\end{array}$ & $\begin{array}{l}.06 \\
.59 \\
.09 \\
.33 \\
.59\end{array}$ & $\begin{array}{r}.00 \\
1.15 \\
.00 \\
.01 \\
.00\end{array}$ & $\begin{array}{l}.07 \\
.00 \\
.11 \\
.01 \\
.00\end{array}$ & $\begin{array}{l}.01 \\
.02 \\
.01 \\
.00 \\
.00\end{array}$ & $\begin{array}{l}.00 \\
.00 \\
.00 \\
.00 \\
.08\end{array}$ & $\begin{array}{r}.08 \\
.01 \\
.10 \\
.45 \\
1.07\end{array}$ & $\begin{array}{l}.06 \\
.01 \\
.09 \\
.21 \\
.07\end{array}$ & $\begin{array}{l}.04 \\
.00 \\
.00 \\
.00 \\
.00\end{array}$ & $\begin{array}{l}.54 \\
.42 \\
.07 \\
.00 \\
.00\end{array}$ & $\begin{array}{r}.00 \\
.00 \\
3.34 \\
.00 \\
.26\end{array}$ & $\begin{array}{l}.31 \\
.01 \\
.02 \\
.25 \\
.01\end{array}$ & $\begin{array}{l}.00 \\
.34 \\
.04 \\
.68 \\
.03\end{array}$ \\
\hline $\begin{array}{r}6 \\
7 \\
8 \\
9 \\
10\end{array}$ & $\begin{array}{r}.16 \\
.01 \\
.69 \\
1.91 \\
.42\end{array}$ & $\begin{array}{l}.00 \\
.18 \\
.02 \\
.17 \\
.32\end{array}$ & $\begin{array}{l}.03 \\
.00 \\
.00 \\
.00 \\
.00\end{array}$ & $\begin{array}{l}.09 \\
.43 \\
.08 \\
.01 \\
.00\end{array}$ & $\begin{array}{l}.00 \\
.00 \\
.03 \\
.04 \\
.04\end{array}$ & $\begin{array}{l}.01 \\
.00 \\
.02 \\
.02 \\
.28\end{array}$ & $\begin{array}{l}.02 \\
.01 \\
.77 \\
.37 \\
.00\end{array}$ & $\begin{array}{l}.83 \\
.01 \\
.00 \\
.00 \\
.00\end{array}$ & $\begin{array}{l}.72 \\
.03 \\
.22 \\
.42 \\
.74\end{array}$ & $\begin{array}{r}.00 \\
.00 \\
1.27 \\
.90 \\
.45\end{array}$ & $\begin{array}{l}.00 \\
.00 \\
.75 \\
.30 \\
.20\end{array}$ & $\begin{array}{l}.27 \\
.00 \\
.00 \\
.07 \\
.18\end{array}$ \\
\hline $\begin{array}{l}11 \\
12 \\
13 \\
14 \\
15\end{array}$ & $\begin{array}{l}.48 \\
.53 \\
.22 \\
.00 \\
.00\end{array}$ & $\begin{array}{l}.08 \\
.18 \\
.03 \\
.01 \\
.08\end{array}$ & $\begin{array}{l}.00 \\
.50 \\
.51 \\
.00 \\
.03\end{array}$ & $\begin{array}{l}.19 \\
.00 \\
.02 \\
.36 \\
.01\end{array}$ & $\begin{array}{l}.00 \\
.00 \\
.08 \\
.00 \\
.00\end{array}$ & $\begin{array}{l}.02 \\
.00 \\
.00 \\
.00 \\
.66\end{array}$ & $\begin{array}{l}.00 \\
.17 \\
.27 \\
.44 \\
.03\end{array}$ & $\begin{array}{l}.04 \\
.07 \\
.49 \\
.00 \\
.01\end{array}$ & $\begin{array}{l}.00 \\
.00 \\
.00 \\
.00 \\
.69\end{array}$ & $\begin{array}{l}.02 \\
.50 \\
.02 \\
.00 \\
.00\end{array}$ & $\begin{array}{r}1.25 \\
.34 \\
.00 \\
.00 \\
1.53\end{array}$ & $\begin{array}{r}.00 \\
.01 \\
.00 \\
1.99 \\
.01\end{array}$ \\
\hline $\begin{array}{l}16 \\
17 \\
18 \\
19 \\
20\end{array}$ & $\begin{array}{l}.00 \\
.01 \\
.01 \\
.00 \\
.00\end{array}$ & $\begin{array}{l}.11 \\
.01 \\
.00 \\
.00 \\
.00\end{array}$ & $\begin{array}{l}.04 \\
.01 \\
.13 \\
.00 \\
.00\end{array}$ & $\begin{array}{l}.00 \\
.05 \\
.33 \\
.00 \\
.00\end{array}$ & $\begin{array}{l}.38 \\
.00 \\
.09 \\
.00 \\
.04\end{array}$ & $\begin{array}{l}.02 \\
.16 \\
.60 \\
.00 \\
.00\end{array}$ & $\begin{array}{l}.24 \\
.00 \\
.01 \\
.00 \\
.01\end{array}$ & $\begin{array}{l}.00 \\
.24 \\
.21 \\
.26 \\
.80\end{array}$ & $\begin{array}{r}1.26 \\
.00 \\
.00 \\
.00 \\
.00\end{array}$ & $\begin{array}{l}.00 \\
.67 \\
.00 \\
.00 \\
.00\end{array}$ & $\begin{array}{r}.05 \\
.00 \\
2.31 \\
.56 \\
.11\end{array}$ & $\begin{array}{l}.00 \\
.03 \\
.01 \\
.01 \\
.00\end{array}$ \\
\hline $\begin{array}{l}21 \\
22 \\
23 \\
24 \\
25\end{array}$ & $\begin{array}{l}.00 \\
.00 \\
.05 \\
.03 \\
.03\end{array}$ & $\begin{array}{l}.00 \\
.00 \\
.00 \\
.24 \\
.01\end{array}$ & $\begin{array}{r}.00 \\
.00 \\
.00 \\
1.04 \\
.42\end{array}$ & $\begin{array}{l}.00 \\
.21 \\
.01 \\
.00 \\
.17\end{array}$ & $\begin{array}{l}.15 \\
.29 \\
.21 \\
.00 \\
.01\end{array}$ & $\begin{array}{l}.35 \\
.25 \\
.03 \\
.27 \\
.03\end{array}$ & $\begin{array}{l}.04 \\
.01 \\
.00 \\
.12 \\
.00\end{array}$ & $\begin{array}{l}.36 \\
.00 \\
.00 \\
.34 \\
.07\end{array}$ & $\begin{array}{l}.00 \\
.00 \\
.00 \\
.00 \\
.00\end{array}$ & $\begin{array}{l}.00 \\
.83 \\
.19 \\
.01 \\
.00\end{array}$ & $\begin{array}{l}.02 \\
.03 \\
.05 \\
.01 \\
.00\end{array}$ & $\begin{array}{l}.40 \\
.26 \\
.39 \\
.06 \\
.51\end{array}$ \\
\hline $\begin{array}{l}26 \\
27 \\
28 \\
29 \\
30 \\
31\end{array}$ & $\begin{array}{l}.01 \\
.01 \\
.29 \\
.01 \\
.00 \\
.00\end{array}$ & $\begin{array}{l}.52 \\
.00 \\
.07 \\
.00 \\
.00 \\
---\end{array}$ & $\begin{array}{l}.00 \\
.00 \\
.00 \\
.13 \\
.14 \\
.06\end{array}$ & $\begin{array}{l}.02 \\
.21 \\
.00 \\
.00 \\
.00 \\
.00\end{array}$ & $\begin{array}{l}.00 \\
.01 \\
.00 \\
.04 \\
-.- \\
.-\end{array}$ & $\begin{array}{l}.02 \\
.04 \\
.60 \\
.03 \\
.05 \\
.80\end{array}$ & $\begin{array}{r}.87 \\
1.06 \\
.00 \\
.15 \\
1.00 \\
-\end{array}$ & $\begin{array}{r}.00 \\
.00 \\
.00 \\
.00 \\
1.38 \\
.16\end{array}$ & $\begin{array}{l}.00 \\
.06 \\
.00 \\
.08 \\
.09 \\
.--\end{array}$ & $\begin{array}{r}.00 \\
.00 \\
1.15 \\
.00 \\
.00 \\
.00\end{array}$ & $\begin{array}{l}.00 \\
.00 \\
.00 \\
.00 \\
.00 \\
.03\end{array}$ & $\begin{array}{l}.10 \\
.00 \\
.00 \\
.00 \\
.07 \\
.-\end{array}$ \\
\hline TOTAL & 6.53 & 3.19 & 3.23 & 2.23 & 1.49 & 5.97 & 6.03 & 5.31 & 5.34 & 9.61 & 8.14 & 5.46 \\
\hline WTR YR & & TOTAL & 62.53 & & & & & & & & & \\
\hline
\end{tabular}


Table B-1 Continued. Daily precipitation July 1975 to September 1980 at South Spring at Bowden, West Virginia (station number 03068710, site 8)

RAINFALL, ACCUMULATED (INCHES), WATER YEAR OCTOBER 1978 TO SEPTEMBER 1979

\begin{tabular}{|c|c|c|c|c|c|c|c|c|c|c|c|}
\hline OCT & NOV & DEC & JAN & FEB & MAR & APR & MAY & JUN & JUL & AUG & SEP \\
\hline $\begin{array}{l}--- \\
--- \\
.00 \\
.36 \\
.00\end{array}$ & $\begin{array}{l}.00 \\
.00 \\
.00 \\
.00 \\
.00\end{array}$ & $\begin{array}{l}.01 \\
.00 \\
.76 \\
.65 \\
.01\end{array}$ & $\begin{array}{l}.52 \\
.41 \\
.11 \\
.05 \\
.00\end{array}$ & $\begin{array}{l}.00 \\
.00 \\
.06 \\
.00 \\
.05\end{array}$ & $\begin{array}{l}.10 \\
.01 \\
.00 \\
.12 \\
.10\end{array}$ & $\begin{array}{l}.53 \\
.03 \\
.44 \\
.31 \\
.24\end{array}$ & $\begin{array}{l}.00 \\
.00 \\
.32 \\
.33 \\
.04\end{array}$ & $\begin{array}{l}.07 \\
.00 \\
.68 \\
.03 \\
.00\end{array}$ & $\begin{array}{l}.71 \\
.09 \\
.01 \\
.98 \\
.00\end{array}$ & $\begin{array}{l}.06 \\
.08 \\
.00 \\
.00 \\
.00\end{array}$ & $\begin{array}{r}.00 \\
1.77 \\
1.31 \\
.01 \\
.50\end{array}$ \\
\hline $\begin{array}{l}.00 \\
.29 \\
.05 \\
.01 \\
.00\end{array}$ & $\begin{array}{l}.00 \\
.06 \\
.02 \\
.02 \\
.00\end{array}$ & $\begin{array}{r}.00 \\
.07 \\
1.59 \\
.57 \\
.00\end{array}$ & $\begin{array}{l}.00 \\
.90 \\
.00 \\
.00 \\
.00\end{array}$ & $\begin{array}{l}.08 \\
.01 \\
.00 \\
.00 \\
.00\end{array}$ & $\begin{array}{l}.00 \\
.00 \\
.00 \\
.00 \\
.39\end{array}$ & $\begin{array}{l}.04 \\
.00 \\
.01 \\
.61 \\
.07\end{array}$ & $\begin{array}{r}.00 \\
.00 \\
.00 \\
.00 \\
1.04\end{array}$ & $\begin{array}{l}.00 \\
.34 \\
.20 \\
.03 \\
.19\end{array}$ & $\begin{array}{l}.00 \\
.00 \\
.00 \\
.00 \\
.23\end{array}$ & $\begin{array}{l}.00 \\
.00 \\
.13 \\
.02 \\
.27\end{array}$ & $\begin{array}{l}.56 \\
.04 \\
.00 \\
.00 \\
.00\end{array}$ \\
\hline $\begin{array}{l}.00 \\
.00 \\
.00 \\
.20 \\
.07\end{array}$ & $\begin{array}{l}.00 \\
.03 \\
.01 \\
.07 \\
.67\end{array}$ & $\begin{array}{l}.06 \\
.00 \\
.00 \\
.00 \\
.00\end{array}$ & $\begin{array}{l}.00 \\
.02 \\
.30 \\
.10 \\
.00\end{array}$ & $\begin{array}{r}.00 \\
.00 \\
.00 \\
.00 \\
1.49\end{array}$ & $\begin{array}{l}.00 \\
.02 \\
.01 \\
.34 \\
.01\end{array}$ & $\begin{array}{l}.00 \\
.00 \\
.00 \\
.04 \\
.12\end{array}$ & $\begin{array}{l}.07 \\
.81 \\
.30 \\
.01 \\
.15\end{array}$ & $\begin{array}{l}.09 \\
.00 \\
.00 \\
.00 \\
.00\end{array}$ & $\begin{array}{l}.00 \\
.00 \\
.24 \\
.45 \\
.48\end{array}$ & $\begin{array}{r}.22 \\
1.07 \\
.00 \\
.13 \\
.00\end{array}$ & $\begin{array}{l}.00 \\
.00 \\
.01 \\
.80 \\
.01\end{array}$ \\
\hline $\begin{array}{l}.41 \\
.01 \\
.01 \\
.00 \\
.00\end{array}$ & $\begin{array}{l}.24 \\
.31 \\
.00 \\
.00 \\
.01\end{array}$ & $\begin{array}{r}.27 \\
.00 \\
.00 \\
.00 \\
2.11\end{array}$ & $\begin{array}{r}.00 \\
.56 \\
.00 \\
.00 \\
1.56\end{array}$ & $\begin{array}{l}.17 \\
.03 \\
.00 \\
.00 \\
.19\end{array}$ & $\begin{array}{l}.00 \\
.00 \\
.00 \\
.03 \\
.01\end{array}$ & $\begin{array}{l}.09 \\
.03 \\
.00 \\
.00 \\
.00\end{array}$ & $\begin{array}{l}.01 \\
.00 \\
.00 \\
.00 \\
.00\end{array}$ & $\begin{array}{r}.00 \\
.36 \\
1.05 \\
.01 \\
.00\end{array}$ & $\begin{array}{l}.05 \\
.02 \\
.04 \\
.00 \\
.25\end{array}$ & $\begin{array}{r}.02 \\
.00 \\
.70 \\
1.13 \\
.32\end{array}$ & $\begin{array}{l}.00 \\
.00 \\
.00 \\
.02 \\
.00\end{array}$ \\
\hline $\begin{array}{l}.00 \\
.00 \\
.12 \\
.01 \\
.00\end{array}$ & $\begin{array}{l}.00 \\
.00 \\
.76 \\
.11 \\
.00\end{array}$ & $\begin{array}{l}.77 \\
.00 \\
.00 \\
.99 \\
.02\end{array}$ & $\begin{array}{l}.52 \\
.00 \\
.06 \\
.16 \\
.00\end{array}$ & $\begin{array}{l}.14 \\
.01 \\
.48 \\
.68 \\
.26\end{array}$ & $\begin{array}{l}.00 \\
.00 \\
.00 \\
.66 \\
.01\end{array}$ & $\begin{array}{l}.00 \\
.00 \\
.01 \\
.01 \\
.00\end{array}$ & $\begin{array}{l}.29 \\
.01 \\
.44 \\
.91 \\
.27\end{array}$ & $\begin{array}{l}.38 \\
.08 \\
.33 \\
.07 \\
.02\end{array}$ & $\begin{array}{l}.16 \\
.01 \\
.04 \\
.19 \\
.20\end{array}$ & $\begin{array}{l}.05 \\
.00 \\
.01 \\
.00 \\
.49\end{array}$ & $\begin{array}{r}1.28 \\
.33 \\
.07 \\
.00 \\
.00\end{array}$ \\
\hline $\begin{array}{l}.72 \\
.08 \\
.00 \\
.00 \\
.00 \\
.00\end{array}$ & $\begin{array}{r}.00 \\
1.00 \\
.10 \\
.23 \\
.00 \\
-\end{array}$ & $\begin{array}{l}.01 \\
.00 \\
.03 \\
.00 \\
.08 \\
.50\end{array}$ & $\begin{array}{l}.00 \\
.07 \\
.00 \\
.00 \\
.00 \\
.00\end{array}$ & $\begin{array}{l}.01 \\
.00 \\
.27 \\
-2 \\
--- \\
--\end{array}$ & $\begin{array}{l}.00 \\
.00 \\
.00 \\
.00 \\
.00 \\
.40\end{array}$ & $\begin{array}{l}.73 \\
.23 \\
.04 \\
.00 \\
.00 \\
---\end{array}$ & $\begin{array}{l}.18 \\
.33 \\
.14 \\
.00 \\
.00 \\
.07\end{array}$ & $\begin{array}{l}.00 \\
.00 \\
.00 \\
.08 \\
.42 \\
.--\end{array}$ & $\begin{array}{l}.27 \\
.05 \\
.00 \\
.59 \\
.01 \\
.00\end{array}$ & $\begin{array}{l}.03 \\
.64 \\
.00 \\
.05 \\
.00 \\
.00\end{array}$ & $\begin{array}{l}.00 \\
.00 \\
.34 \\
.15 \\
.03 \\
-.-\end{array}$ \\
\hline 2.34 & 3.64 & 8.50 & 5.34 & 3.93 & 2.21 & 3.58 & 5.72 & 4.43 & 5.07 & 5.42 & 7.23 \\
\hline
\end{tabular}


RAINFALL, ACCUMULATED (INCHES), WATER YEAR OCTOBER 1979 TO SEPTEMBER 1980

\begin{tabular}{|c|c|c|c|c|c|c|c|c|c|c|c|c|}
\hline DAY & OCT & NOV & DEC & JAN & FEB & MAR & APR & MAY & JUN & JUL & AUG & SEP \\
\hline $\begin{array}{l}1 \\
2 \\
3 \\
4 \\
5\end{array}$ & $\begin{array}{l}.07 \\
.48 \\
.12 \\
.20 \\
.61\end{array}$ & $\begin{array}{r}.00 \\
1.18 \\
.01 \\
.11 \\
.04\end{array}$ & $\begin{array}{l}.08 \\
.00 \\
.10 \\
.00 \\
.00\end{array}$ & $\begin{array}{l}.00 \\
.00 \\
.00 \\
.00 \\
.00\end{array}$ & $\begin{array}{l}.00 \\
.00 \\
.01 \\
.00 \\
.06\end{array}$ & $\begin{array}{r}.00 \\
.00 \\
.00 \\
.25 \\
1.05\end{array}$ & $\begin{array}{l}.06 \\
.00 \\
.06 \\
.22 \\
.11\end{array}$ & $\begin{array}{l}.02 \\
.00 \\
.00 \\
.00 \\
.00\end{array}$ & $\begin{array}{l}.46 \\
.39 \\
.10 \\
.01 \\
.00\end{array}$ & $\begin{array}{r}.01 \\
.00 \\
3.30 \\
.02 \\
.28\end{array}$ & $\begin{array}{l}.27 \\
.02 \\
.04 \\
.29 \\
.01\end{array}$ & $\begin{array}{l}.01 \\
.30 \\
.02 \\
.65 \\
.04\end{array}$ \\
\hline $\begin{array}{r}6 \\
7 \\
8 \\
9 \\
10\end{array}$ & $\begin{array}{r}.18 \\
.01 \\
.72 \\
2.09 \\
.33\end{array}$ & $\begin{array}{l}.00 \\
.12 \\
.03 \\
.15 \\
.33\end{array}$ & $\begin{array}{l}.01 \\
.01 \\
.00 \\
.00 \\
.00\end{array}$ & $\begin{array}{l}.00 \\
.35 \\
.01 \\
.01 \\
.03\end{array}$ & $\begin{array}{l}.00 \\
.00 \\
.08 \\
.02 \\
.03\end{array}$ & $\begin{array}{l}.12 \\
.00 \\
.00 \\
.03 \\
.27\end{array}$ & $\begin{array}{l}.01 \\
.00 \\
.84 \\
.31 \\
.00\end{array}$ & $\begin{array}{l}.82 \\
.03 \\
.00 \\
.00 \\
.00\end{array}$ & $\begin{array}{l}.82 \\
.04 \\
.25 \\
.57 \\
.68\end{array}$ & $\begin{array}{r}.03 \\
.00 \\
1.49 \\
.88 \\
.44\end{array}$ & $\begin{array}{l}.01 \\
.00 \\
.55 \\
.25 \\
.18\end{array}$ & $\begin{array}{l}.20 \\
.03 \\
.01 \\
.05 \\
.19\end{array}$ \\
\hline $\begin{array}{l}11 \\
12 \\
13 \\
14 \\
15\end{array}$ & $\begin{array}{l}.55 \\
.50 \\
.24 \\
.00 \\
.10\end{array}$ & $\begin{array}{l}.06 \\
.18 \\
.02 \\
.03 \\
.12\end{array}$ & $\begin{array}{l}.00 \\
.49 \\
.52 \\
.00 \\
.01\end{array}$ & $\begin{array}{l}.27 \\
.00 \\
.03 \\
.36 \\
.01\end{array}$ & $\begin{array}{l}.02 \\
.01 \\
.01 \\
.00 \\
.00\end{array}$ & $\begin{array}{l}.14 \\
.07 \\
.02 \\
.00 \\
.56\end{array}$ & $\begin{array}{l}.00 \\
.19 \\
.27 \\
.42 \\
.02\end{array}$ & $\begin{array}{l}.03 \\
.14 \\
.48 \\
.01 \\
.00\end{array}$ & $\begin{array}{l}.01 \\
.01 \\
.00 \\
.00 \\
.66\end{array}$ & $\begin{array}{l}.02 \\
.63 \\
.03 \\
.01 \\
.00\end{array}$ & $\begin{array}{r}.21 \\
1.05 \\
.01 \\
.01 \\
1.07\end{array}$ & $\begin{array}{r}.01 \\
.00 \\
.00 \\
1.08 \\
.14\end{array}$ \\
\hline $\begin{array}{l}16 \\
17 \\
18 \\
19 \\
20\end{array}$ & $\begin{array}{l}.00 \\
.00 \\
.00 \\
.00 \\
.00\end{array}$ & $\begin{array}{l}.08 \\
.13 \\
.00 \\
.03 \\
.00\end{array}$ & $\begin{array}{l}.03 \\
.01 \\
.02 \\
.02 \\
.00\end{array}$ & $\begin{array}{l}.03 \\
.07 \\
.35 \\
.01 \\
.02\end{array}$ & $\begin{array}{l}.29 \\
.00 \\
.12 \\
.04 \\
.00\end{array}$ & $\begin{array}{l}.11 \\
.19 \\
.59 \\
.14 \\
.00\end{array}$ & $\begin{array}{l}.24 \\
.05 \\
.00 \\
.00 \\
.00\end{array}$ & $\begin{array}{r}.00 \\
.35 \\
.17 \\
.26 \\
1.08\end{array}$ & $\begin{array}{r}1.38 \\
.02 \\
.00 \\
.00 \\
.00\end{array}$ & $\begin{array}{l}.00 \\
.81 \\
.01 \\
.01 \\
.00\end{array}$ & $\begin{array}{r}.12 \\
.01 \\
2.32 \\
.51 \\
.12\end{array}$ & $\begin{array}{l}.01 \\
.01 \\
.01 \\
.01 \\
.00\end{array}$ \\
\hline $\begin{array}{l}21 \\
22 \\
23 \\
24 \\
25\end{array}$ & $\begin{array}{l}.00 \\
.00 \\
.01 \\
.03 \\
.03\end{array}$ & $\begin{array}{l}.00 \\
.00 \\
.00 \\
.18 \\
.02\end{array}$ & $\begin{array}{l}.00 \\
.00 \\
.00 \\
.97 \\
.48\end{array}$ & $\begin{array}{l}.09 \\
.13 \\
.01 \\
.00 \\
.31\end{array}$ & $\begin{array}{l}.17 \\
.31 \\
.16 \\
.00 \\
.02\end{array}$ & $\begin{array}{l}.36 \\
.27 \\
.07 \\
.29 \\
.06\end{array}$ & $\begin{array}{l}.00 \\
.00 \\
.00 \\
.07 \\
.02\end{array}$ & $\begin{array}{l}.34 \\
.02 \\
.08 \\
.50 \\
.07\end{array}$ & $\begin{array}{l}.00 \\
.00 \\
.00 \\
.00 \\
.00\end{array}$ & $\begin{array}{l}.00 \\
.81 \\
.30 \\
.02 \\
.01\end{array}$ & $\begin{array}{l}.02 \\
.05 \\
.05 \\
.02 \\
.01\end{array}$ & $\begin{array}{l}.38 \\
.23 \\
.45 \\
.05 \\
.47\end{array}$ \\
\hline $\begin{array}{l}26 \\
27 \\
28 \\
29 \\
30 \\
31\end{array}$ & $\begin{array}{l}.02 \\
.13 \\
.31 \\
.00 \\
.00 \\
.00\end{array}$ & $\begin{array}{l}.57 \\
.02 \\
.04 \\
.03 \\
.00 \\
---\end{array}$ & $\begin{array}{l}.00 \\
.00 \\
.01 \\
.15 \\
.01 \\
.00\end{array}$ & $\begin{array}{l}.02 \\
.07 \\
.00 \\
.00 \\
.00 \\
.00\end{array}$ & $\begin{array}{l}.00 \\
.00 \\
.00 \\
.00 \\
--- \\
--\end{array}$ & $\begin{array}{l}.02 \\
.06 \\
.62 \\
.03 \\
.06 \\
.85\end{array}$ & $\begin{array}{l}.86 \\
.96 \\
.01 \\
.18 \\
.99 \\
-.-\end{array}$ & $\begin{array}{r}.01 \\
.00 \\
.00 \\
.00 \\
1.36 \\
.19\end{array}$ & $\begin{array}{l}.00 \\
.00 \\
.01 \\
.11 \\
.15 \\
-.-\end{array}$ & $\begin{array}{l}.00 \\
.00 \\
.87 \\
.02 \\
.01 \\
.01\end{array}$ & $\begin{array}{l}.00 \\
.00 \\
.00 \\
.00 \\
.03 \\
.01\end{array}$ & $\begin{array}{l}.09 \\
.01 \\
.01 \\
.01 \\
.02 \\
-\end{array}$ \\
\hline TOTAL & 6.73 & 3.48 & 2.92 & 2.18 & 1.35 & 6.23 & 5.89 & 5.96 & 5.67 & 10.02 & 7.24 & 4.49 \\
\hline WTR YF & & TOTAL & 62.16 & & & & & & & & & \\
\hline
\end{tabular}


